\title{
Stream fish populations in a watershed scale context for fish community dynamics in central Appalachian watersheds
}

\author{
Zina Hense \\ West Virginia University
}

Follow this and additional works at: https://researchrepository.wvu.edu/etd

\section{Recommended Citation}

Hense, Zina, "Stream fish populations in a watershed scale context for fish community dynamics in central Appalachian watersheds" (2007). Graduate Theses, Dissertations, and Problem Reports. 2534. https://researchrepository.wvu.edu/etd/2534

This Thesis is protected by copyright and/or related rights. It has been brought to you by the The Research Repository @ WVU with permission from the rights-holder(s). You are free to use this Thesis in any way that is permitted by the copyright and related rights legislation that applies to your use. For other uses you must obtain permission from the rights-holder(s) directly, unless additional rights are indicated by a Creative Commons license in the record and/ or on the work itself. This Thesis has been accepted for inclusion in WVU Graduate Theses, Dissertations, and Problem Reports collection by an authorized administrator of The Research Repository @ WVU. For more information, please contact researchrepository@mail.wvu.edu. 
Stream Fish Populations in a Watershed Scale Context for Fish Community Dynamics in Central Appalachian Watersheds

\title{
Zina Hense
}

\author{
A Thesis \\ Submitted to the \\ Davis College of Agriculture, Forestry, and Consumer Sciences \\ at West Virginia University \\ in partial fulfillment of the requirements \\ for the degree of \\ Master of Science \\ In \\ Wildlife and Fisheries Resources
}

\author{
J. Todd Petty, Ph.D., Chair \\ Stuart A. Welsh, Ph.D. \\ Amy Hessl, Ph.D. \\ Wildlife and Fisheries Program of the Division of Forestry \\ Morgantown, West Virginia \\ 2007
}

Keywords: capture probability, Cheat River, electrofishing, scale, spatial population structure, stream fishes, Tygart Valley River, watershed distribution 


\section{Abstract \\ Stream Fish Populations in a Watershed Scale Context for Fish Community Dynamics in Central Appalachian Watersheds}

\section{Zina Hense}

In this study we first conducted a three pass removal study to estimate electrofishing capture probabilities for species and size classes of fish common in the Cheat River and Tygart River watersheds of West Virginia. We then calculated models of capture probabilities for 12 species that were divided into two size classes based on site-specific physico-chemical variables. We took these capture probability models and applied them to a watershed scale study in the Cheat River and Tygart Valley River watersheds of West Virginia. We sampled across the two watersheds with the objective of quantifying and relating juvenile and adult distributions within species along a stream size continuum. The 14 species that were included in the study we found to be mostly nonuniformly distributed across the watershed. We used general stream size to categorize where the concentrations of each species and size class were, in relation to the watershed and each other. Our analyses determined among species variations in the degree of overlap of juvenile and adult distributions within species. We generally related watershed population and community level organization to the within species juvenile and adult distributions. 
Stream Fish Populations in a Watershed Scale Context for Fish Community Dynamics in Central Appalachian Watersheds

\section{Zina Hense Acknowledgments}

I thank my committee for their assistance in completing this project. A special nod to Todd Petty for the research opportunity, the guidance and support with the project, and his patience with all of the time, the number of drafts, and the extra explanations necessary for me to complete this thesis. This research was partially funded by the National Research Center for Coal and Energy and a US EPA STAR grant. In the course of my graduate experience, I have received much help, advice, and support also from labmates Roy Martin, Zach Liller, Ira Poplar-Jeffers, George Merovich, and Jason Clingerman. I thank Jen Fulton for providing me with invaluable advice, both personal and professional. Special thanks go to everyone who contributed to collection of data including, but not limited to: Jason Freund, Anthony Grubb, Mike Nicholas, Lee Haggerty, Logan Walmsley, Zachary Golightly, and Seth Lemley. And I'm grateful always to Mom and Tato for the emotional, financial, editing, fieldwork, and horse-care support. Thanks to officemates in Percival 339 for acting as a sounding board and providing technical support. And thanks to WV friends Shawn Crimmins, Jen Lowery, Alison Mynesberge, and Lisa Tager for the both the fun and not quite so fun times we've had. 


\section{Table of Contents}

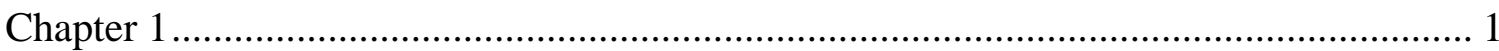

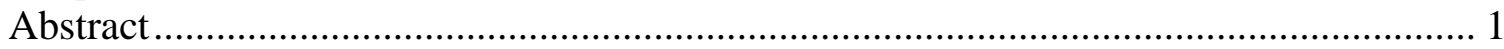

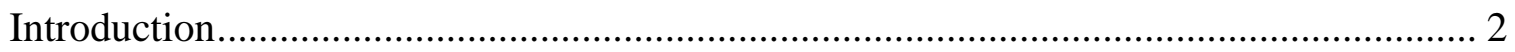

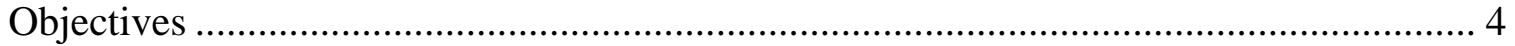

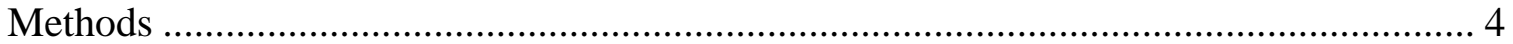

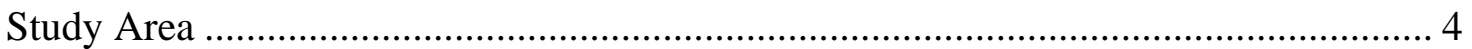

Site Selection ............................................................................................... 5

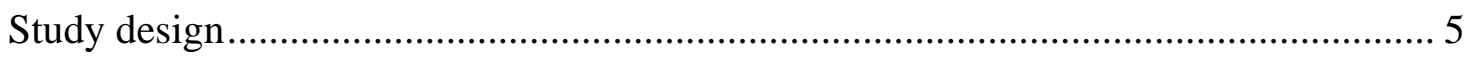

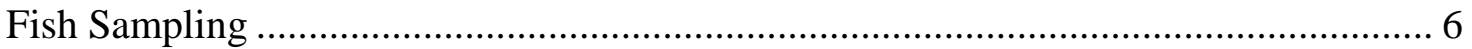

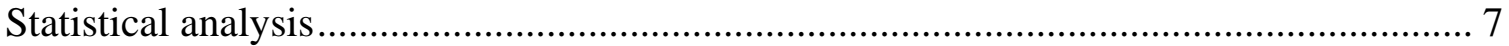

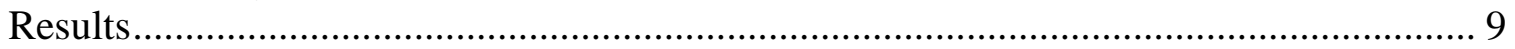

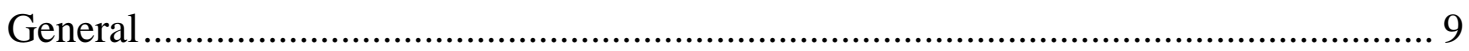

Program MARK and Model Selection.................................................................... 9

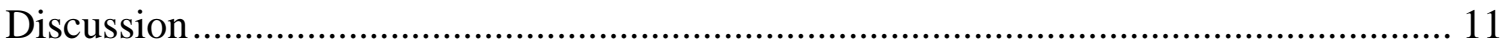

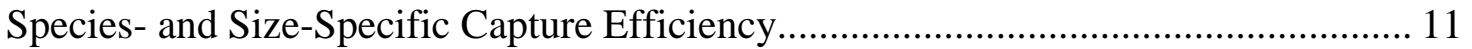

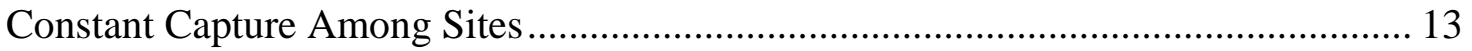

Capture Efficiency Variable Among Sites............................................................... 14

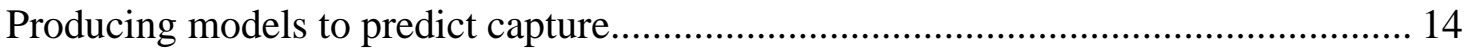

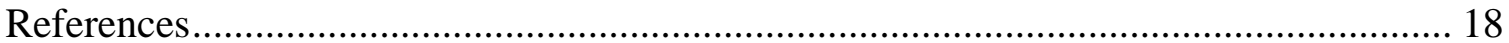

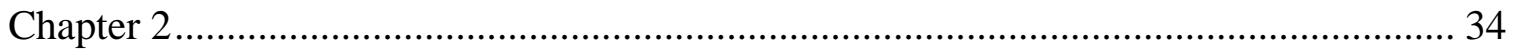

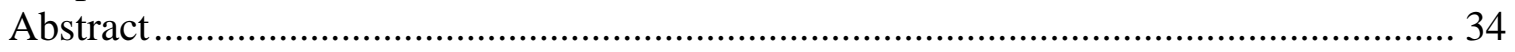

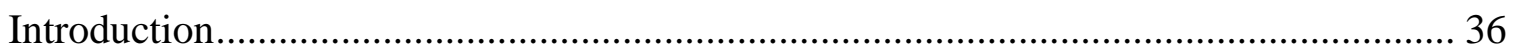

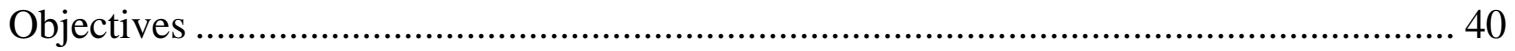

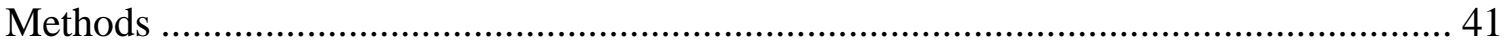

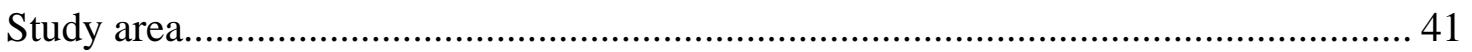

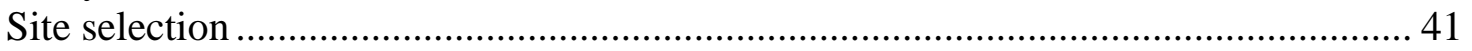

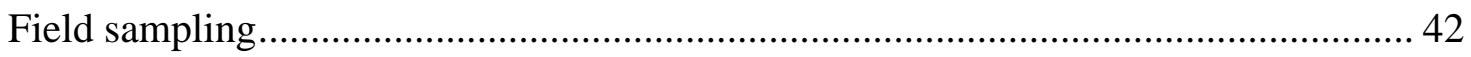

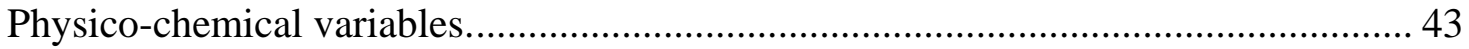

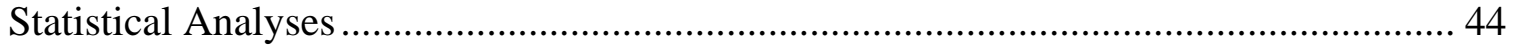

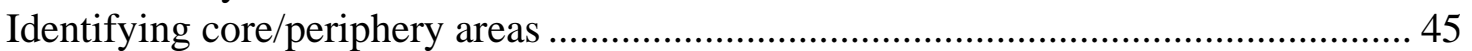

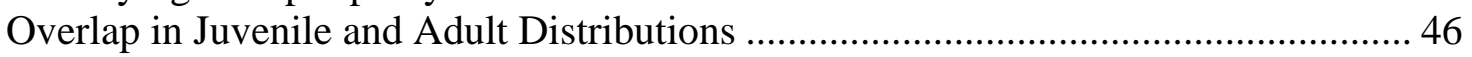

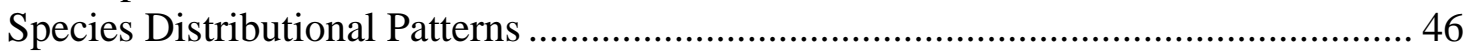

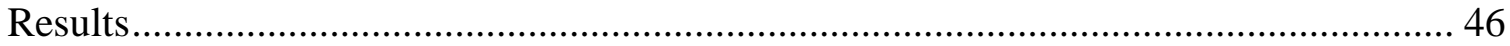

Non-Uniform Distribution Across Watershed ....................................................... 46

Adult and Juvenile Distribution Correlation............................................................. 48

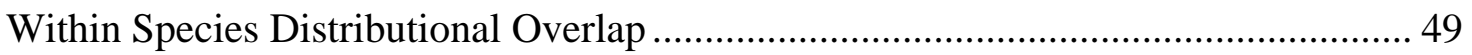

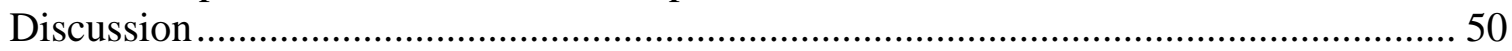

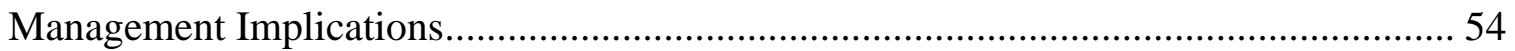

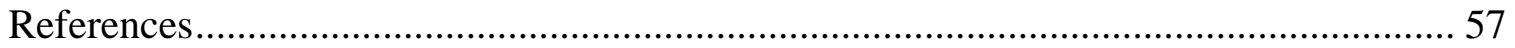

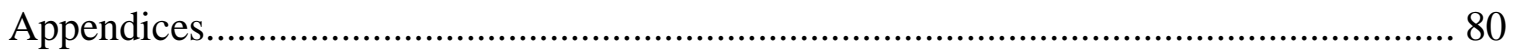




\section{List of Tables}

\section{Chapter 1}

Table 1. List of fishes captured during three pass depletion sampling. Species names, juvenile/adult size cutoffs, common names, and abbreviations are shown.

Table 2. The total number of sites and individual fish captured during three pass depletion sampling. List includes species and sizes captured, but excluded from further study, and depletion pass failure.

Table 3. A priori models constructed in the program MARK to test for significant spatial variation in capture efficiency.

Table 4. Correlation of transformed physico-chemical values used to generate predictive models of capture efficiency.

Table 5. Summary of the Program MARK capture efficiency model evaluations including model name, $\mathrm{AIC}_{\mathrm{c}}$ value, delta $\mathrm{AICc}$, the $\mathrm{AICc}$ weight, the number of parameters, and the deviance associated with the model for each population and size class.

Table 6. Species and size classes assigned a constant among sites model by the program MARK. Constant capture efficiency and MARK generated standard error shown.

Table 7. Multiple regression models to predict site, size, and taxon specific capture efficiencies for groups with spatial variation in capture success.

Table 8. Species and size classes that the program MARK identified as variable capture efficiency among sites, but for which no significant predictive models could be generated. Mean capture efficiency and standard error are shown.

Table 9. Comparison of capture efficiencies between published studies and our own study.

\section{Chapter 2}

Table 1. Summary characteristics of the 47 sites that were sampled in the Cheat River and Tygart Valley River watersheds of WV.

Table 2. List of fish included in our analyses, including scientific name, common name, abbreviation, and juvenile/adult size cutoff. 
Table 3. Summary of core and periphery distributions by species and size class, sorted by upstream boundary of core range. Edges of core and periphery defined in $\mathrm{km}^{2}$ basin area. The results of the Kolmogorov-Smirnov goodness of fit test between each species and size distribution and the expected, and the coefficient of correlation between the log abundance values for each species are provided.

\section{List of Figures}

\section{Chapter 1}

Figure 1. Locations of sampled sites within the Cheat River and Tygart Valley River watersheds of West Virginia.

Figure 2. An example of the length frequency histograms used to determine juvenile and adult age cutoffs.

Figure 3. Relationships between physico-chemical variables and observed capture probabilities at sites sampled.

\section{Chapter 2}

Figure 1. Locations of the sites sampled for this study in the Cheat River and Tygart Valley River watersheds of West Virginia

Figure 2. An example of the length frequency histograms used to determine juvenile and adult age cutoffs.

Figure 3. Example model showing how cumulative percent abundance corresponds to boundaries of lower periphery, core, and upper periphery associations with basin area sizes of stream sampled.

Figure 4. Example figure showing cumulative distribution of a species across a basin area, and how we calculated range overlap of the adult and juvenile population.

Figure 5. Cumulative proportional abundances by species, across increasing basin areas. Species are identified as small-, intermediate-, large-, or ubiquitous-core species. Graphs include adult, juvenile, and expected distributions.

Figure 6. Juvenile log abundance plotted against adult log abundance at site for sites with fish present. Plots include 1:1 line and line of best fit.

Figure 7. Core and periphery distributions across basin area size in the watershed. 


\title{
Chapter 1
}

Species- and Size-Specific Electrofishing Capture Efficiencies for Fishes Common in Central Appalachian Watersheds

\begin{abstract}
As larger-scale stream studies are becoming more common, a need has developed for accurate estimation of fish population abundance and density estimates with singlepass electrofishing. However, few studies have quantified intra- and interspecific variability in fish capture probabilities. Consequently, our objectives were to 1) determine which species and size classes within species exhibited significant spatial variation in electrofishing efficiency, and 2) construct models to predict species and size specific capture probability from physico-chemical parameters. We used three-pass removal sampling to capture fishes in the Cheat River and Tygart Valley River watersheds of West Virginia. The program MARK was used to estimate capture efficiency and to assess significant among-site variability of capture. We then used stepwise linear regression modeling to construct models to predict capture efficiency. Our analyses produced models for twelve species. The physico-chemical variable that most influenced capture efficiencies was conductivity. This study indicates that capture efficiency is constant for most species and size classes of temperate fishes. Our results also indicate that, if a species or size class is variable in capture efficiency, site specific capture probabilities can be estimated from a suite of easily obtained physico-chemical parameters. Consequently, it should be possible to use single-pass electrofishing to infer population level phenomena in watershed-scale studies.
\end{abstract}




\section{Introduction}

Single-pass electrofishing capture efficiency is variable by species, size, gear, and locale (Reynolds 1996), and yet single-pass sampling is essential to many aspects of fisheries science and management. Single-pass sampling can cover a greater area with less expenditure in time, effort, and resources than is required by multiple-pass electrofishing (Meador et al. 2003). The advantage of this increased scale of data collection makes single-pass sampling a valuable approach. There has been an increase in stream studies that link local and regional scales to examine impacts on fish population dynamics, and this has resulted in an increasing amount of watershed-scale studies (Schlosser 1991). The coverage and scale that single-pass sampling allow are important to Indices of Biotic Integrity (IBIs), which are used to evaluate biological conditions, most often regionally (Fausch et al. 1984), and in riverscape assemblage studies (Heimbuch et al. 1997). Another advantage of single-pass sampling is that it allows temporal trends to be examined, because it simplifies long-term data collection (Meador et al. 2003). The interest in expanding the scale of lotic study to a watershed scale has put a premium on sampling efficiency, which is reflected in increased interest in singlepass sampling (Meador et al. 2003).

There are, however, inherent limitations to the accuracy of single-pass electrofishing data. Single-pass sampling can accurately describe assemblages and provide presence/absence data (Meador et al. 2003; Bertrand et al. 2006). However, single-pass data are strongly influenced by capture efficiency (Kruse et al. 1998) when estimating total and proportional population abundances. The limitation of single-pass electrofishing is that the accuracy of the electrofishing capture efficiency is highly 
variable due to many physical and chemical factors. There have been documented interand intra-specific variations in sampling efficiency due to habitat complexity and fish orientation, morphology, and size (Reynolds 1996; Thompson and Rahel 1996). Environmental factors such as conductivity, water clarity, temperature, depth, cover, discharge, and sampling equipment can all influence capture efficiency. These variations may render unreliable the relative abundance estimates obtained with single-pass sampling (Reynolds et al. 2003).

Removal electrofishing has been used to increase the reliability and precision of population size estimates (Zippin 1956: Rosenberger and Dunham 2005). Multiple passes help to compensate for differences in capture efficiencies of different fishes (Thompson 2003), and also increase the chances of sampling rare and cryptic species (Meador et al. 2003). Multi-pass depletion sampling can approximate abundances of most species in an assemblage. However, multi-pass sampling is more often used for distinct populations rather than communities because of its time, labor, and resource intensive requirements (Meador et al. 2003).

Single-pass backpack electrofishing may provide useful abundance estimates if sufficient information is known about its ability to assess the fish assemblages being sampled. We produced models to properly calibrate single-pass data to account for the variability in capture among species, size classes, and the sampling environment. These models, based on local physico-chemical variables and fish species and size, adjust single-pass data to better estimate relative abundances for the area sampled. Other researchers have produced capture efficiency models, but nearly all of these studies are limited to salmonids or centrarchids (Hill and Willis 1994; Hayes and Baird 1994; 
Peterson and Dunham 2003; D. Peterson et al. 2004; J. Peterson et al. 2004; Rosenberger and Dunham 2005). Such studies are not applicable to a temperate stream study where fish assemblages are dominated by cottids and cyprinids. Heimbuch et al. (1997) created models for temperate stream fishes, but they pooled all capture histories across streams, which did not account for the variation that sometimes exists between streams. We created models that account for variation in capture efficiency between species and size classes as well as among streams for the majority of the common species in Appalachian temperate streams.

\section{Objectives}

Given the importance of capture efficiency in obtaining reliable estimates of population size from single-pass studies and the lack of information on most Appalachian stream fish taxa, we conducted a study that addressed the following objectives:

1. Determine which species, and which size-classes within species, exhibited significant spatial variation in electrofishing capture efficiency;

2. Construct empirical models capable of predicting size and species-specific capture efficiencies from readily obtainable physico-chemical parameters.

\section{Methods}

Study Area

We conducted this study in the Cheat River and Tygart Valley River watersheds during the summers of 2002-2005. The Cheat River watershed, which drains approximately $3,700 \mathrm{~km}^{2}$, is formed by the confluence of the Shavers and Black Forks at Parsons, WV, and is part of the upper Monongahela basin. The Cheat River watershed is affected by acid mine drainage; however, the majority of our study was conducted in the 
upper regions of the watershed where coal mining is rare and numerous high quality streams persist (Freund 2004). The Tygart Valley River watershed drains $3,522 \mathrm{~km}^{2}$, and is also part of the Monongahela River basin. The Tygart Valley River watershed is also impacted by acid mine drainage and acid precipitation (Freund 2004), but we confined the majority of our study to the higher quality upper region of the watershed to avoid these anthropogenic effects.

\section{Site Selection}

We selected 40 study sites within the Cheat River and Tygart Valley River watersheds containing stream fish assemblages typical to this area (Figure 1). Sites were representative of the area; they were selected across a wide range of drainage areas (0.1$124 \mathrm{~km}^{2}$ ), bedrock geologies (sandstone, shale, and limestone), and gradients (0.2-17.2 \%). Streams averaged 0.8-15 m wide, with conductivity that ranged from 22-192 $\mu \mathrm{s} / \mathrm{cm}$. We did not sample any sites impaired by acid mine drainage, acid precipitation, or other signs of anthropogenic disturbance. Following the guidelines of Freund and Petty (2007), reach segments sampled were generally 40 times mean stream width, with a minimum length of $80 \mathrm{~m}$ and a maximum length of $300 \mathrm{~m}$.

\section{Study design}

We used current knowledge about site-specific variables that affect electrofishing efficiency to predict which physico-chemical variables would contribute to electrofishing efficiency variability in our study (Hill and Willis 1994; Reynolds 1996; Meador et al. 2003). Our selections were based on feasibility of collection, such that they might be applied to future studies without requiring significantly more expenditure in time or equipment. We then applied correlation analysis to identify and eliminate redundant 
variables in the dataset. For each of our study sites, we determined conductivity $(\mu \mathrm{s} / \mathrm{cm})$, mean stream width (m), and gradient (\%). Specific conductivity was measured on-site with a 600 XL Multi-Parameter Water Quality Monitor (YSI Incorporated, Yellow Springs, Ohio). Mean stream width was averaged from three wetted-width measurements across each reach. We determined gradient with a handheld clinometer on-site.

\section{Fish Sampling}

Streams were sampled using three-pass depletion electrofishing methods during the summer months of 2002-2005. We sampled in late July and August to allow for effective sampling of juvenile fishes. We used block nets $(5 \mathrm{~mm}$ mesh) at both the top and bottom of each segment to ensure a closed population during sampling. Two to four person teams, dependant on stream size, were equipped with backpack shockers (Smith Root, DC, $60 \mathrm{hz}, 400-600 \mathrm{~V}$ ), dip nets, and a portable seine. Sampling was conducted systematically in an upstream direction.

All fishes captured during electrofishing were anesthetized in clove oil (concentration $=40 \mathrm{mg} / \mathrm{L}$ ), identified to species, measured (standard length, nearest $\mathrm{mm}$ ), weighed (nearest $0.01 \mathrm{~g}$ ), and then held in live wells until the completion of sampling. The fishes were returned to the stream after sampling was completed. As our study addressed species and size-specific efficiencies, size classes were determined for each species in each year of study (Table 1). We measured fish to the nearest millimeter (standard length), and pooled data across sites to construct length-frequency histograms (Figure 2). We compared our length frequencies to literature (Jenkins and Burkhead 1994), and fishes were assigned to one of two size classes, either adult or juvenile (Table 
1). We captured a total of 19 species of fish, 12 of which were caught in sufficient number to model capture efficiency (Table 2).

\section{Statistical Analyses}

Our first objective was to determine whether each taxon and size class exhibited constant or variable capture efficiency across sites. We analyzed species- and sizespecific capture histories with maximum-likelihood estimators using two capture efficiency models in the program MARK (White and Burnham 1999). The first candidate model predicted a constant capture efficiency across sites, and the other predicted a variable capture efficiency across sites (Table 3). We set the recapture parameter to 0 to estimate capture efficiencies and manually set the number of parameters for each model. We ran capture histories separately for each species and size class. Species with fewer than 30 total fish sampled across sites (Riley and Fausch 1992), or with samples from fewer than three sites, were not included in the analyses due to the limited scope and utility of data. Thus, our analyses were constrained to 12 species: rock bass (Ambloplites rupestris), central stoneroller (Campostoma anomalum), white sucker (Catostomus commersoni), rosyside dace (Clinostomus funduloides), mottled sculpin (Cottus bairdi), fantail darter (Etheostoma flabellare), northern hogsucker (Hypentelium nigricans), smallmouth bass (Micropterus dolomieu), blacknose dace (Rhinichthys obtusus), longnose dace (Rhinichthys cataractae), brook trout (Salvelinus fontinalis), and creek chub (Semotilus atromaculatus) (Table 2).

We entered our a priori hypotheses (constant or variable among sites) of capture efficiencies using two candidate models. We then selected the best fitting model for each group using the Akaike's Information Criterion ( $\mathrm{AIC}_{\mathrm{c}}$ ) weighting assigned by the 
program MARK adjusted for small sample size (Burnham and Anderson 2002). We assigned one model rather than model averaging because there were only two candidate models.

Our second objective was to construct empirical models to predict species-, size-, and site-specific capture efficiency. The species identified as constant among sites have a single capture efficiency value assigned by the program MARK. We then constructed models for species and size classes identified as having variable capture among sites. The capture efficiencies $(\hat{\mathrm{p}})$ were matched with the physico-chemical variables basin area, gradient, conductivity, and mean stream width. Conductivity and mean stream width were log transformed and gradient was arcsine transformed to approximate normality. We used linear forward stepwise regression (Pollock et al. 1984; J. Peterson et al. 2004) in SAS (version 9.1, Cary, North Carolina) to determine which physicochemical parameters were included in the models. We performed principal component analysis and correlation analysis on the variables to eliminate redundant predictor variables (Table 4). The highest correlation was $r=0.58$, between mean stream width and gradient; however, while these two variables were correlated, we did not omit either because there are many streams in the basin where one does not necessarily indicate the other and other related values such as substrate size are more time and resource consumptive to collect. Using a statistical significance value of $\alpha=0.15$ for variable inclusion, models were constructed for the species and size classes where applicable. We used a significance value of $\alpha=0.05$ to determine acceptance of the overall model. 


\section{Results}

General

In this removal study, a total of 25,319 fishes were captured among 40 sites within the Cheat River and Tygart Valley River watersheds during the summers 20022005. We captured 19 species in all, and analyzed the capture efficiencies of 12 species. Green sunfish (Lepomis cyanellus), bluegill (Lepomis macrochirus), river chub (Nocomis micropogon), rainbow trout (Oncorhynchus mykiss), mountain redbelly dace (Phoxinus oreas), bluntnose minnow (Pimephales notatus), and brown trout (Salmo trutta) were excluded from all analyses because of insufficient data. For the species that were included in analyses, we created adult and juvenile size classes for ten species, including rock bass, central stoneroller, rosyside dace, mottled sculpin, fantail darter, northern hogsucker, longnose dace, blacknose dace, brook trout, and creek chub (Table 2). Smallmouth bass and white sucker were analyzed at juvenile size only because of the limited number of adults captured.

\section{Program MARK and Model Selection}

The Program MARK was used to estimate site-, size-, and taxon-specific capture efficiencies from three pass depletion data, and to assess whether capture efficiency varied spatially (Table 5). We fit the two candidate models to estimate capture efficiency to each species and size class. Using Aikaike's model selection criteria, we determined that the majority of age groups in our study, 16 of 22 size classes, did not exhibit spatial variation in capture efficiency (Table 6). For rockbass adult, central stoneroller adult and juvenile, white sucker juvenile, rosyside dace adult, mottled sculpin juvenile, fantail darter adult and juvenile, northern hogsucker adult and juvenile, smallmouth bass 
juvenile, longnose dace adult, brook trout adult and juvenile, and creek chub adult and juvenile, a constant capture efficiency model more closely fit the observed data. The Program MARK quantified a best estimate of capture efficiency to represent these groups at each site (Table 6). Estimates of capture efficiency for these species ranged from a low of $\hat{p}=0.42$ for fantail darter juvenile, to a high of $\hat{p}=0.83$ for white sucker juvenile (Table 6).

The minority of groups in our study, (6 out of 22) of the size classes, were determined to exhibit spatial variation in capture efficiency. In the absence of a constant capture rate across sites, we employed multiple stepwise regression analysis to determine which of the pre-selected physico-chemical variables influenced capture efficiency. We were able to construct significant models for half ( 3 of 6 ) of the variable species and size classes (Table 7). The species and size classes that we were able to fit significant models to included the rock bass juvenile, longnose dace juvenile, and blacknose dace adult. Mean estimates of capture efficiencies for these groups had a close range from 0.70 for longnose dace juvenile to a 0.73 for adult blacknose dace.

The significant models of capture efficiency were able to explain a range of variability (Table 7). The model $\mathrm{R}^{2}$ ranged from $0.78-0.98$. The physico-chemical variables combinations were successful in explaining the capture efficiency of different size classes. Each of the physico-chemical variables we selected was significant in at least one model (Table 7). Conductivity appeared to be the most influential variable in this study. Increasing conductivity resulted in an increase in capture efficiency (Figure 3). 
We were not able to construct significant models to predict capture efficiency for 3 of the 6 size classes that the Program MARK identified as variable among sites (Table 8). These fishes included rosyside dace juvenile, mottled sculpin adult, and blacknose dace juvenile.

\section{Discussion}

Species- and Size-Specific Capture Efficiency

Results from this study provide new information about the capture efficiencies of species and size classes of temperate Appalachian stream fishes. Using the program MARK with three-pass depletion data, we generated species- and size-specific capture efficiencies. These capture efficiencies were comparable to previous studies. Generally, other studies have noted that cyprinids and centrarchids are fishes that exhibit lower capture probabilities overall (Heimbuch et al. 1997; Meador et al. 2003). There was no distinction in capture efficiency between centrarchids and cyprinids and the other families of fishes in our study. Our highest capture efficiencies were for white sucker juvenile and northern hogsucker adult, and our lowest capture efficiencies were for mottled sculpin (juvenile $\hat{p}=0.51$ ), rock bass (adult $\hat{p}=0.51$ ) and fantail darter (juvenile $\hat{p}=0.42$ ); the cyprinids and centrarchids fell in the middle range of capture efficiencies in our study (smallmouth bass juvenile $\hat{p}=0.73$, central stoneroller juvenile $\hat{\mathrm{p}}=0.64)$. There are few other multi-species efficiency studies that include darters, sculpin, and other benthic species, instead they concentrate primarily on game fishes, so this could be why centrarchids and cyprinds have the lowest capture efficiencies in other studies but are middling range in our study. When we compare game fish in our study, brook trout and smallmouth bass have capture efficiencies that are in relatively the same 
range; brook trout adult $=0.77$, brook trout juvenile $=0.69$ and smallmouth bass $=0.73$. However, the rock bass adult capture efficiency are substantially lower with adult $=0.51$, the juvenile mean efficiency is 0.72 , though with a wider range than brook trout or smallmouth bass. Our salmonid capture efficiencies are close to findings in other studies (Table 9). The mean capture efficiencies that we found for brook trout were $\hat{p}=0.69$ 0.77, near the ranges found by Riley and Fausch (1992), Thompson and Rahel (1996), and D. Peterson et al. (2004).

We incorporated size classes into our study to be able to better estimate the capture of the population as a whole, because of the reported effect of size on electrofishing efficiency. The wide discrepancies in capture efficiency that we observed between the adult and juvenile groups of some species justify this step. A populationlevel capture estimate would not accurately represent the local abundance of age classes for species like rock bass (adult $\hat{p}=0.51$, juvenile $\hat{p}=0.72$ ), northern hogsucker (adult $\hat{\mathrm{p}}=0.80$, juvenile $\hat{\mathrm{p}}=0.56$ ), and creek chub (adult $\hat{\mathrm{p}}=0.74$, juvenile $\hat{\mathrm{p}}=0.60$ ). With the exception of centrarchid and salmonid literature, we could not find published comparisons for our juvenile capture efficiencies. Riley and Fausch (1992) found a significant difference between juvenile and adult salmonids in their study. Our ranges of capture efficiencies for brook trout populations were comparable to theirs (Table 9). Riley and Fausch (1992) found that adult trout had a higher capture efficiency than did juveniles in most of their sites sampled. We also observed a higher rate of capture with the adult trout in our study (adult efficiency $=0.77$, juvenile efficiency $=$ 0.69). Among all of the species in general, we found a general trend toward either adults within species having higher capture efficiency than the juveniles, in keeping with reports 
that the overall length of spine is a determinant of capture efficiency, with larger fishes within species being more susceptible to capture (Reynolds 1996). Juveniles had higher mean capture efficiency than adults for rock bass, longnose dace, and blacknose dace. The capture rates of adults exceed juveniles for central stoneroller, rosyside dace, mottled sculpin, fantail darter, northern hogsucker, brook trout, and creek chub. Because we did not compute an adult capture efficiency rate for white sucker and smallmouth bass, we could not compare the adult and juvenile capture rates for those species. Although we observed higher capture efficiencies for juveniles within species groups, among all of the species, there was no clear divide between juvenile and adult capture. The mean estimated adult capture efficiencies in our study ranged from $0.51-0.80$, and the mean of juvenile capture rates ranged from $0.42-0.83$.

\section{Constant Capture Among Sites}

There were 16 size classes that the program MARK identified as having constant among-site capture efficiency. The species and size classes with constant models do not have consistently higher or lower capture efficiencies than the variable groups. In our study, juvenile mottled sculpin had relatively consistent low capture efficiency from stream to stream $(\hat{\mathrm{p}}=0.51, \pm 0.018)$. This lower capture efficiency follows suggestions in the literature that sculpin are not as affected by lethal and sublethal effects of electroshocking as are many other species (Barrett and Grossman 1998). Among those studies that do include non-game fishes, we could not find a capture efficiency study that successfully generated capture efficiency for mottled sculpin. Fantail darter juveniles had

a constant low capture efficiency as well $(\hat{\mathrm{p}}=0.42, \pm 0.089)$. Both fantail darter and mottled sculpin are small benthic species that are cryptically colored and do not have 
swim bladders. Because of their size, the way that they orient themselves along the stream bed, and negative buoyancy, these species can be lost in the substrate during electroshocking runs, preventing higher capture rates.

Brook trout and creek chub were on the other end of the spectrum in terms of capture efficiency. They were also constant among sites and exhibited generally high capture with relatively little variability. Brook trout adult $\hat{p}=0.77, \pm 0.013$ and creek chub adult $\hat{\mathrm{p}}=0.74, \pm 0.039$. Both brook trout and creek chub are larger water column species. They are more brightly colored, and have swim bladders, both of which help when sampling and capturing stunned fish.

\section{Capture Efficiency Variable Among Sites}

Six of the species in our study had among-site variation in capture efficiency. The mean estimated capture efficiency by population ranged from $0.55-0.82$, but each species and size class had an individual range of capture efficiency associated with it. The variable groups exhibited different patterns of capture efficiency. The range of capture could be wide and highly variable (0.40-1.00) as for the blacknose dace adult, or more narrow like the mottled sculpin adult $(0.49-0.62)$. The wide spread of estimated capture efficiency and variability associated with some species and size class' capture efficiencies further emphasizes the need for models that are tailored to each species and size class.

Producing models to predict capture

One of the obstacles to using capture efficiency and single-pass capture data to estimate a population is the significant spatial variation in electrofishing capture efficiency. We were able to construct models to predict capture efficiency for 19 of the 
22 of the size classes that we sample. While the majority of the size classes exhibited constant among site capture, there were six size classes that the program MARK had identified as having spatial variance in capture efficiencies. Of these six, we were able to construct significant models for three size classes, based on three easily collected physico-chemical variables. These variables were fairly successful in accounting for the heterogeneity of capture efficiency. Mean stream width was a significant variable in two of the models that we constructed, reflecting the area and amount of water electrofished. This is consistent with other studies. J. Peterson et al. (2004) found that area, crosssectional in their case, was correlated with capture. Conductivity also contributed to capture efficiency variability, figuring into two of the models. Conductivity was positively correlated with capture efficiency. Conductivity has been excluded in some other DC capture efficiency studies (Hill and Willis 1994; Edwards et al. 1997), but those streams had generally higher conductivity than those in our study. Although Hill and Willis' (1994) model of DC electroshocking did not detect any significant influence from conductivity, they did remark that with more observations it would likely be a factor. Conductivity could have had a significant effect in our study because several of the streams had exceptionally low conductivity $(22-24 \mu \mathrm{s} / \mathrm{cm})$, and the overall efficiency of electrofishing has been shown to be highly limited at such low conductivity levels (Fisher and Brown 1993). There is also variation in some species' $\hat{p}$ between published studies and our own that could possibly be explained by physico-chemical parameters and other sampling specifics. For example, a comparison of our capture efficiency estimates to other studies for rosyside dace, smallmouth bass, and white sucker. Capture efficiencies from Wiley and Tsai (1983) differed more substantially species-to-species from our 
calculated efficiencies than did other studies (Table 9). Although the streams they sampled were of comparable size, the capture efficiencies that Wiley and Tsai (1983) produced may have been a product of the AC electroshocker or the Piedmont system they studied.

Unfortunately, we could not identify significant models to predict capture efficiencies for 3 of the species and size classes that the program MARK identified as having spatially variable capture efficiency. There are several reasons why we may not have been able to generate significant models for these groups. It could be that the capture efficiencies of these fishes are better modeled by predictor variables that we did not include in our study. Other studies have used variables such as distance to cover, and number of removal passes (Peterson and Cederholm 1984), which may be better suited to estimate capture efficiency of certain species and size classes. Sampling crews can be a factor. Our sampling crew was not as efficient at capturing small and cryptically colored species like mottled sculpin and fantail darter as they were at capturing large and colorful species like brook trout. Because of all of the factors that do influence capture efficiency, modeling capture efficiency may always be problematic for some species. Some species' capture efficiencies may remain inestimable with the method we used because of rarity, low-density, or morphological aspects; however, it is not always necessary or practical to reform sampling protocol to cater to rare species (Reynolds et al. 2003; Meador et al. 2003).

No single method is most applicable across all streams, habitats, fishes and sizes (Heggenes et al. 1990); nonetheless, we believe our models of capture efficiency have utility. To the best of our knowledge, this is the first study attempting to model capture 
efficiency variability relative to stream characteristics for non-game fishes. As population studies on stream fishes continue, such knowledge will be highly applicable to future research. As watershed-scale studies expand, single-pass sampling becomes a necessity. The ability to use single-pass studies to address population dynamics at this larger scale is pivotal in saving time, equipment, and expense, so long as effective numbers can be produced. A reliable and stable conversion factor for relative density and abundance is key to expanding sampling effort (Schwarz and Seber 1999).

This study is necessarily limited in scope and use. These models and capture efficiencies were compiled in two distinct watersheds, and would probably not be accurate in other watersheds because of water and landscape characteristics and differences in local fish assemblages. The models are also rather specific to the general time frame of this study. Water quality, even within the Cheat River and Tygart Valley River watersheds can change, and because conductivity was a major component in many of the models, changing water conditions can affect capture efficiency. Electrofishing equipment changes over time as well, and different gear will require a recalibration of models, as will different sampling crews and techniques. These are the first models to be produced for most of these species and size classes, and additional studies are needed to expand utility and validity of the dataset. 


\section{References}

Barrett J.C., and G.D. Grossman. 1988. Effects of direct current electrofishing on the mottled sculpin. North American Journal of Fisheries Management 8:112-116.

Bertrand K.N., K.B. Gido, and C.S. Guy. 2006. An evaluation of single-pass versus multiple-pass backpack electrofishing to estimate trends in species abundance and richness in prairie streams. Transactions of the Kansas Academy of Science.

Burnham, K.P., and D.R. Anderson. 2002. Model Selection and Multi-Model Inference: A Practical Information-Theoretic Approach, $2^{\text {nd }}$ edition New York: SpringerVerlag

Edwards, C.M., R.W. Drenner, K.L. Gallo, and K.E. Rieger. 1997. Estimation of population density of largemouth bass in ponds by using mark-recapture and electrofishing catch per effort. North American Journal of Fisheries Management 17:719-725.

ESRI (Environmental Systems Research Institute). 2005. ARCGIS, desktop version 9.1. ESRI, Redlands, California.

Fausch, K.D., J.R. Karr, and P.R. Yant. 1984. Regional application of an index of biotic integrity based on stream fish communities. Transactions of the American Fisheries Society 113: 39-55.

Fisher, W.L., and M.E. Brown. 1993. A prepositioned aerial electrofishing apparatus for sampling stream habitats. North American Journal of Fisheries Management 13:807-816.

Freund, J.G. 2004. Local and regional impairment of fish assemblages in a mined Appalachian watershed. Dissertation submitted to the Davis College of Agriculture, Forestry, and Consumer Sciences at West Virginia University.

Freund, J.G., and J.T. Petty. 2007. Response of fish and macroinvertebrate bioindices to specific stressor levels in a mined Appalachian watershed. Environmental Management 00:00-00 (IN PRESS).

Hayes J.W., and D.B. Baird. 1994. Estimating relative abundance of juvenile brown trout in rivers by underwater census and electrofishing. New Zealand Journal of Marine and Freshwater Research 28:243-253.

Heggenes J, A. Brabrand, and S.J. Saltveit. 1990. Comparison of three methods for studies of stream habitat use by young brown trout and atlantic salmon. Transactions of the American Fisheries Society 119:101-111. 
Heimbuch D.G., H.T. Wilson, S.B. Wisberg, and J.H. Volstad, P.F. Kazyak. 1997. Estimating abundance in stream surveys by using double-pass removal sampling. Transactions of the American Fisheries Society 126:795-803.

Hill, T.D. and D.W. Willis. 1994. Influence of water conductivity on pulsed AC and pulsed DC electrofishing catch rates for largemouth bass. North American Journal of Fisheries Management 14:202-207.

Jenkins, R.E. and N.M. Burkhead. 1994. Freshwater fishes of Virginia. American Fisheries Society, Bethesda, MD.

Kruse, C.G., and W.A. Hubert, and F.J. Rahel. 1998. Single-pass electrofishing predicts trout abundance in mountain streams with sparse habitat. North American Journal of Fisheries Management 18: 940-946.

Meador, M.R., J.P. McIntyre, and K.H. Pollock. 2003. Assessing the efficacy of singlepass backpack electrofishing to characterize fish community structure. Transactions of the American Fisheries Society 132:39-46.

Peterson, D.P., K.D. Fausch, and G.C. White. 2004. Population ecology of an invasion: effects of brook trout on native cutthroat trout. Ecological Applications 14:754-772.

Peterson, J.T., and J. Dunham. 2003. Combining inferences from models of capture efficiency, detectability, and suitable habitat to classify landscapes for conservation of threatened bull trout. Conservation Biology 17(4):1070-1077.

Peterson, J.T., R.F. Thurow, and J.W. Guzevich. 2004. An evaluation of multipass electrofishing for estimating the abundance of stream-dwelling salmonids. Transactions of the American Fisheries Society 133:462-475.

Peterson, N.P., and C.J. Cederholm. 1984. A comparison of the removal and markrecapture methods of population estimation for juvenile coho salmon in a small stream. North American Journal of Fisheries Management. 4:99-102

Pollock, K.H., J.E. Hines, and J.D. Nichols. 1984. The use of auxiliary variables in capture-recapture and removal experiments. Biometrics 40.2:329-340.

Reynolds, J.B. 1996. Electrofishing. In Murphy, B.R. \& D.W. Willis (eds), Fisheries Techniques. $2^{\text {nd }}$ edn. American Fisheries Society, Maryland :221-253.

Reynolds L., A.T. Herlihy, P.R. Kaughfmann, S.V. Gregory, and R.M. Hughes. 2003. Electrofishing effort requirements for assessing species richness and biotic integrity in western Oregon streams. North American Journal of Fisheries Management 23:450-461. 
Riley, S.C., and K.D. Fausch. 1992. Underestimation of trout population size by maximum-likelihood removal estimates in small streams. North American Journal of Fisheries Management 12:768-776.

Rosenberger, A.E., and J.B. Dunham. 2005. Validation of abundance estimates from mark-recapture and removal techniques for rainbow trout captured by electrofishing in small streams. North American Journal of Fisheries Management 25.

Schlosser, I.J. 1991. Stream fish ecology: A landscape perspective. BioScience 41:704-712.

Schwarz, C.J., and G.A.F. Seber. 1999. Estimating animal abundance: Review III. Statistical Science 14: 427-456.

Thompson, P.D., and F.J. Rahel. 1996. Evaluation of depletion-removal electrofishing of brook trout in small Rocky Mountain streams. North American Journal of Fisheries Management 16:332-339.

Thompson, W.L. 2003. Hankin and Reeves' approach to estimating fish abundance in small stream: limitations and alternatives. Transactions of the American Fisheries Society 132: 69-75.

White, G.C., D.R. Anderson, K.P. Burnham, and D.L. Otis. 1982. Capture-recapture and removal methods for sampling closed populations. Report LA-8787-NERP. Los Alamos National Laboratory, Los Alamos, New Mexico, USA.

White, G.C., and K.P. Burnham. 1999. Program MARK: survival estimation from populations of marked animals. Bird Study 46 Supplement :120-138.

Wiley, M.L., and C. Tsai. 1983. The relative efficiencies of electrofishing vs. seines in Piedmont streams of Maryland. North American Journal of Fisheries Management 3:243-253.

Zar, J.H. 1999. Biostatistical Analysis: Fourth Edition. Prentice Hall, Upper Saddle River, New Jersey.

Zippin, C. 1956. An evaluation of the removal method of estimating animal populations. Biometrics 12(2):163-189. 
Table 1.-Fishes captured during three pass depletion sampling. Species names, juvenile/adult size cutoffs (standard length), common names, and abbreviations are shown. N/A marks sizes of fishes that we did not catch in sufficient number to analyze.

\begin{tabular}{llll}
\hline Species & $\begin{array}{l}\text { Size class cutoff } \\
(\mathrm{mm})\end{array}$ & Common Name & Abbreviation \\
\hline Ambloplites rupestris & 110 & Rock bass & AMRU \\
Campostoma anomalum & 60 & Central stoneroller & CAAN \\
Catostomus commersoni & 180 & White sucker & CACO \\
Clinostomus funduloides & 50 & Rosyside dace & CLFU \\
Cottus bairdi & 47 & Mottled sculpin & COBA \\
Etheostoma flabellare & 33 & Fantail darter & ETFL \\
Hypentelium nigricans & 109 & Northern hogsucker & HYNI \\
Lepomis cyanellus & N/A & Green sunfish & LECY \\
Lepomis macrochirus & N/A & Bluegill & LEMA \\
Micropterus dolomieu & 215 & Smallmouth bass & MIDO \\
Nocomis micropogon & N/A & River chub & NOMI \\
Oncorhynchus mykiss & N/A & Rainbow trout & ONMY \\
Phoxinus oreas & N/A & Mountain redbelly dace & PHOR \\
Pimephales notatus & N/A & Bluntnose minnow & PINO \\
Rhinichthys cataractae & 56 & Longnose dace & RHCA \\
Rhinichthys obtusus & 44 & Blacknose dace & RHOB \\
Salmo trutta & N/A & Brown trout & SATR \\
Salvelinus fontinalis & 79 & Eastern brook trout & SAFO \\
Semotilus atromaculatus & 83 & Creek chub & SEAT \\
\hline
\end{tabular}


Table 2.- The total number of sites and individual fish captured during three-pass depletion sampling. List includes species and sizes captured, but excluded from further study, and depletion pass failure.

\begin{tabular}{|c|c|c|c|}
\hline Species & Age Class & N Sites & $\mathrm{N}$ fish \\
\hline \multirow[t]{2}{*}{ AMRU } & Adult & 4 & 168 \\
\hline & Juvenile & 6 & 303 \\
\hline \multirow[t]{2}{*}{ CAAN } & Adult & 6 & 392 \\
\hline & Juvenile & 3 & 256 \\
\hline \multirow[t]{2}{*}{$\mathrm{CACO}$} & Adult & 5 & 8 \\
\hline & Juvenile & 8 & 34 \\
\hline \multirow[t]{2}{*}{ CLFU } & Adult & 7 & 190 \\
\hline & Juvenile & 5 & 201 \\
\hline \multirow[t]{2}{*}{ COBA } & Adult & 13 & 1944 \\
\hline & Juvenile & 8 & 1298 \\
\hline \multirow[t]{2}{*}{ ETFL } & Adult & 8 & 124 \\
\hline & Juvenile & 3 & 74 \\
\hline \multirow[t]{2}{*}{ HYNI } & Adult & 6 & 55 \\
\hline & Juvenile & 5 & 218 \\
\hline \multirow[t]{2}{*}{ LECY } & Adult & 0 & -- \\
\hline & Juvenile & 3 & -- \\
\hline \multirow[t]{2}{*}{ LEMA } & Adult & 1 & -- \\
\hline & Juvenile & 0 & -- \\
\hline \multirow[t]{2}{*}{ MIDO } & Adult & 3 & 10 \\
\hline & Juvenile & 4 & 53 \\
\hline \multirow[t]{2}{*}{ NOMI } & Adult & 4 & -- \\
\hline & Juvenile & 4 & -- \\
\hline \multirow[t]{2}{*}{ ONMY } & Adult & 1 & -- \\
\hline & Juvenile & 1 & -- \\
\hline \multirow[t]{2}{*}{ PHOR } & Adult & 1 & -- \\
\hline & Juvenile & 1 & -- \\
\hline \multirow[t]{2}{*}{ PINO } & Adult & 2 & -- \\
\hline & Juvenile & 2 & -- \\
\hline \multirow[t]{2}{*}{ RHCA } & Adult & 10 & 175 \\
\hline & Juvenile & 5 & 100 \\
\hline \multirow[t]{2}{*}{ RHOB } & Adult & 11 & 990 \\
\hline & Juvenile & 8 & 251 \\
\hline \multirow[t]{2}{*}{ SATR } & Adult & 4 & -- \\
\hline & Juvenile & 2 & -- \\
\hline \multirow[t]{2}{*}{ SAFO } & Adult & 30 & 701 \\
\hline & Juvenile & 28 & 640 \\
\hline \multirow[t]{2}{*}{ SEAT } & Adult & 9 & 109 \\
\hline & Juvenile & 8 & 312 \\
\hline
\end{tabular}


Table 3.-A priori models constructed in the program MARK to test for significant spatial variation in capture efficiency.

Model Hypothesized structure of electrofishing Description of model capture probabilities

\begin{tabular}{lll}
\hline Constant & $\hat{\mathrm{p}}()$. & Capture is constant among sites \\
Variable & $\hat{\mathrm{p}}($ site $)$ & Capture varies among site \\
\hline
\end{tabular}


Table 4.-Correlation of transformed physico-chemical values used to generate predictive models of capture efficiency.

\begin{tabular}{llll}
\hline & Gradient & MSW & Conductivity \\
Gradient & 1.00 & & \\
MSW & --0.58 & 1.00 & \\
& $(<0.0001)$ & & \\
Conductivity & -0.22 & 0.19 & 1.00 \\
& $(<0.0001)$ & $(0.20)$ & \\
\hline
\end{tabular}


Table 5.- Summary of Program MARK capture efficiency model evaluations including model name, AIC $_{\mathrm{c}}$ value, the difference between the AIC values for the two proposed models, the $\mathrm{AIC}_{\mathrm{c}}$ weight $\left(\mathrm{w}_{\mathrm{i}}\right)$, the number of parameters $(\mathrm{K})$, and the deviance associated with the model for each population $(\mathrm{P})$ and size class, adult $(\mathrm{A})$ and juvenile $\left.(\mathrm{J}) . \mathrm{C}^{*}\right)$ denotes the model selected following AIC methodology.

\begin{tabular}{|c|c|c|c|c|c|c|}
\hline Species (Age Class) & Model & AICc & Delta $\mathrm{AIC}_{\mathrm{c}}$ & $\mathrm{w}_{\mathrm{i}}$ & $\mathrm{K}$ & Deviance \\
\hline \multirow[t]{2}{*}{ AMRU (A) } & Variable & -903.561 & 2.84 & 0.194 & 8 & 9.2 \\
\hline & Constant* & -906.405 & 0 & 0.806 & 4 & 14.6 \\
\hline \multirow[t]{2}{*}{ AMRU (J) } & Variable* & -1873.99 & 0 & 0.996 & 12 & 11.5 \\
\hline & Constant & -1863.10 & 10.89 & 0.004 & 6 & 34.6 \\
\hline \multirow[t]{2}{*}{ CAAN (A) } & Variable & -2258.99 & 0.63 & 0.422 & 12 & 25.5 \\
\hline & Constant* & -2259.62 & 0 & 0.578 & 6 & 37.1 \\
\hline \multirow[t]{2}{*}{ CAAN (J) } & Variable & -1479.78 & 5.19 & 0.075 & 6 & 17.1 \\
\hline & Constant* & -1484.97 & 0 & 1.000 & 3 & 18.0 \\
\hline \multirow[t]{2}{*}{ CACO (J) } & Variable & -5.29 & 14.02 & 0.000 & 16 & 1.8 \\
\hline & Constant* & -19.31 & 0 & 0.999 & 8 & 8.7 \\
\hline \multirow[t]{2}{*}{ CLFU (A) } & Variable & -752.84 & 8.01 & 0.012 & 14 & 13.1 \\
\hline & Constant* & -761.65 & 0 & 0.988 & 7 & 18.8 \\
\hline \multirow[t]{2}{*}{ CLFU (J) } & Variable* & -863.22 & 0 & 0.743 & 10 & 17.0 \\
\hline & Constant & -861.10 & 2.12 & 0.257 & 5 & 29.4 \\
\hline \multirow[t]{2}{*}{ COBA (A) } & Variable* & -13145.88 & 0 & 0.905 & 26 & 67.1 \\
\hline & Constant & -13141.37 & 4.51 & 0.095 & 13 & 97.8 \\
\hline \multirow[t]{2}{*}{ COBA (J) } & Variable & -9207.93 & 6.88 & 0.031 & 16 & 47.5 \\
\hline & Constant* & -9214.81 & 0 & 0.969 & 8 & 56.7 \\
\hline \multirow[t]{2}{*}{ ETFL (A) } & Variable & -346.15 & 4.86 & 0.081 & 16 & 14.5 \\
\hline & Constant* & -351.01 & 0 & 0.909 & 8 & 26.8 \\
\hline \multirow[t]{2}{*}{ ETFL (J) } & Variable & -172.55 & 4.62 & 0.090 & 6 & 18.7 \\
\hline & Constant* & -177.17 & 0 & 0.907 & 3 & 20.3 \\
\hline \multirow[t]{2}{*}{ HYNI (A) } & Variable & -103.33 & 10.90 & 0.004 & 12 & 3.9 \\
\hline & Constant* & -114.23 & 0 & 0.996 & 6 & 6.5 \\
\hline
\end{tabular}




\begin{tabular}{|c|c|c|c|c|c|c|}
\hline Species (Age Class) & Model & $\mathrm{AICc}$ & Delta $\mathrm{AIC}_{\mathrm{c}}$ & $\mathrm{W}_{\mathrm{i}}$ & $\mathrm{K}$ & Deviance \\
\hline \multirow[t]{2}{*}{ HYNI (J) } & Variable & -1018.90 & 3.79 & 0.131 & 10 & 15.3 \\
\hline & Constant* & -1022.69 & 0 & 0.869 & 5 & 21.8 \\
\hline \multirow[t]{2}{*}{ MIDO (J) } & Variable & -122.48 & 7.08 & 0.028 & 8 & 4.8 \\
\hline & Constant* & -129.56 & 0 & 0.971 & 4 & 6.4 \\
\hline \multirow[t]{2}{*}{ RHCA (A) } & Variable & -463.69 & 12.88 & 0.001 & 20 & 24.3 \\
\hline & Constant* & -476.78 & 0 & 0.999 & 10 & 32.5 \\
\hline \multirow[t]{2}{*}{ RHCA (J) } & Variable* & -297.51 & 0 & 0.982 & 10 & 11.8 \\
\hline & Constant & -289.56 & 7.95 & 0.018 & 5 & 30.3 \\
\hline \multirow[t]{2}{*}{ RHOB (A) } & Variable* & -6708.10 & 0 & 1.000 & 22 & 57.9 \\
\hline & Constant & -6651.19 & 56.91 & 0.000 & 11 & 137.1 \\
\hline \multirow[t]{2}{*}{ RHOB (J) } & Variable* & -1281.57 & 0 & 0.999 & 16 & 10.0 \\
\hline & Constant & -1260.50 & 21.07 & 0.000 & 8 & 47.6 \\
\hline \multirow[t]{2}{*}{ SAFO (A) } & Variable & -2488.87 & 18.67 & 0.000 & 60 & 47.6 \\
\hline & Constant* & -2507.54 & 0 & 0.999 & 30 & 91.6 \\
\hline \multirow[t]{2}{*}{ SAFO (J) } & Variable & -2193.27 & 24.69 & 0.000 & 56 & 54.5 \\
\hline & Constant* & -2217.96 & 0 & 1.000 & 28 & 88.4 \\
\hline \multirow[t]{2}{*}{ SEAT (A) } & Variable & -174.27 & 15.32 & 0.000 & 18 & 6.6 \\
\hline & Constant* & -189.59 & 0 & 0.999 & 9 & 11.4 \\
\hline \multirow[t]{2}{*}{ SEAT (J) } & Variable & -1806.50 & 5.30 & 0.066 & 16 & 20.8 \\
\hline & Constant* & -1811.80 & 0 & 0.934 & 8 & 31.9 \\
\hline
\end{tabular}


Table 6.- Species and size classes assigned a constant among sites model by the program MARK. Constant capture efficiency and MARK generated standard error shown.

\begin{tabular}{lcc}
\hline Species & Size Class & $\hat{p}(\mathrm{SE})$ \\
\hline AMRU & Adult & $0.51(0.051)$ \\
CAAN & Adult & $0.66(0.027)$ \\
CAAN & Juvenile & $0.64(0.035)$ \\
CACO & Juvenile & $0.83(0.059)$ \\
CLFU & Adult & $0.75(0.029)$ \\
COBA & Juvenile & $0.51(0.018)$ \\
ETFL & Adult & $0.55(0.054)$ \\
ETFL & Juvenile & $0.42(0.089)$ \\
HYNI & Adult & $0.80(0.047)$ \\
HYNI & Juvenile & $0.56(0.042)$ \\
MIDO & Juvenile & $0.73(0.052)$ \\
RHCA & Adult & $0.66(0.033)$ \\
SAFO & Adult & $0.77(0.013)$ \\
SAFO & Juvenile & $0.69(0.015)$ \\
SEAT & Adult & $0.74(0.039)$ \\
SEAT & Juvenile & $0.60(0.032)$ \\
\hline
\end{tabular}


Table 7.-Multiple regression models to predict site, size, and taxon specific capture efficiencies for groups with spatial variation in capture success. Variables in models are log transformed basin area (ba), conductivity (cond), mean stream width (msw) and arcsine square root transformed gradient (grad).

\begin{tabular}{lllllll}
\hline Species & Size Class & Model & Model R & Model p-value & Mean $\hat{\mathrm{p}}(\mathrm{min}-\mathrm{max})$ & $\mathrm{SE}$ \\
\hline AMRU & Juvenile & $=-0.76+(-9.23 \mathrm{grad})+(1.10 \mathrm{cond})+(0.46 \mathrm{msw})$ & 0.98 & 0.02 & $0.72(0.21-1.00)$ \\
RHCA & Juvenile & $=-0.20+(6.90 \mathrm{grad})$ & 0.78 & 0.04 & $0.70(0.37-1.00)$ \\
RHOB & Adult & $=-1.17+(0.73 \mathrm{cond})+(0.77 \mathrm{msw})$ & 0.87 & 0.0009 & 0.10 \\
\hline
\end{tabular}


Table 8.- Species and size classes that the program MARK identified as variable capture efficiency among sites, but for which no significant predictive models could be generated. Mean capture efficiency and standard error are shown.

\begin{tabular}{llll}
\hline Species & Size Class & Model & Mean $\hat{\mathrm{p}}(\mathrm{SE})$ \\
& & & \\
\hline CLFU & Juvenile & Variable & $0.63(0.07)$ \\
COBA & Adult & Variable & $0.55(0.02)$ \\
RHOB & Juvenile & Variable & $0.82(0.06)$ \\
\hline
\end{tabular}


Table 9.-Comparison of capture efficiencies between published studies and our own study. For results from our study, the first number listed is the adult capture efficiency, and the second number is the juvenile, unless otherwise specified.

\begin{tabular}{llll}
\hline Source & Species & Capture efficiency & Our mean $\hat{\mathrm{p}}$ \\
\hline Heimbuch et al. 1997 & ETFL & 0.648 & $0.55 / 0.42$ \\
& SEAT & 0.708 & $0.74 / 0.60$ \\
& SAFO & 0.71 & $0.77 / 0.69$ \\
Wiley and Tsai 1983 & CAAN & 0.53 & $0.66 / 0.64$ \\
& CACO & 0.64 & $0.83(\mathrm{~J})$ \\
& CLFU & 0.74 & $0.75 / 0.63$ \\
& MIDO & 0.60 & $0.73(\mathrm{~J})$ \\
& RHOB & 0.76 & $0.73 / 0.82$ \\
& SEAT & 0.70 & $0.74 / 0.60$ \\
Thompson and Rahel 1996 & SAFO & $0.59-1.00$ (adult) & 0.77 \\
Riley and Fausch 1992 & & $0.73-1.00$ (juvenile) & 0.69 \\
& SAFO & Range $0.55-0.77$ & $(0.36-1.00) \mathrm{A}$ \\
D. Peterson et al. 2004 & & & $0.47-1.00) \mathrm{J}$ \\
\hline
\end{tabular}



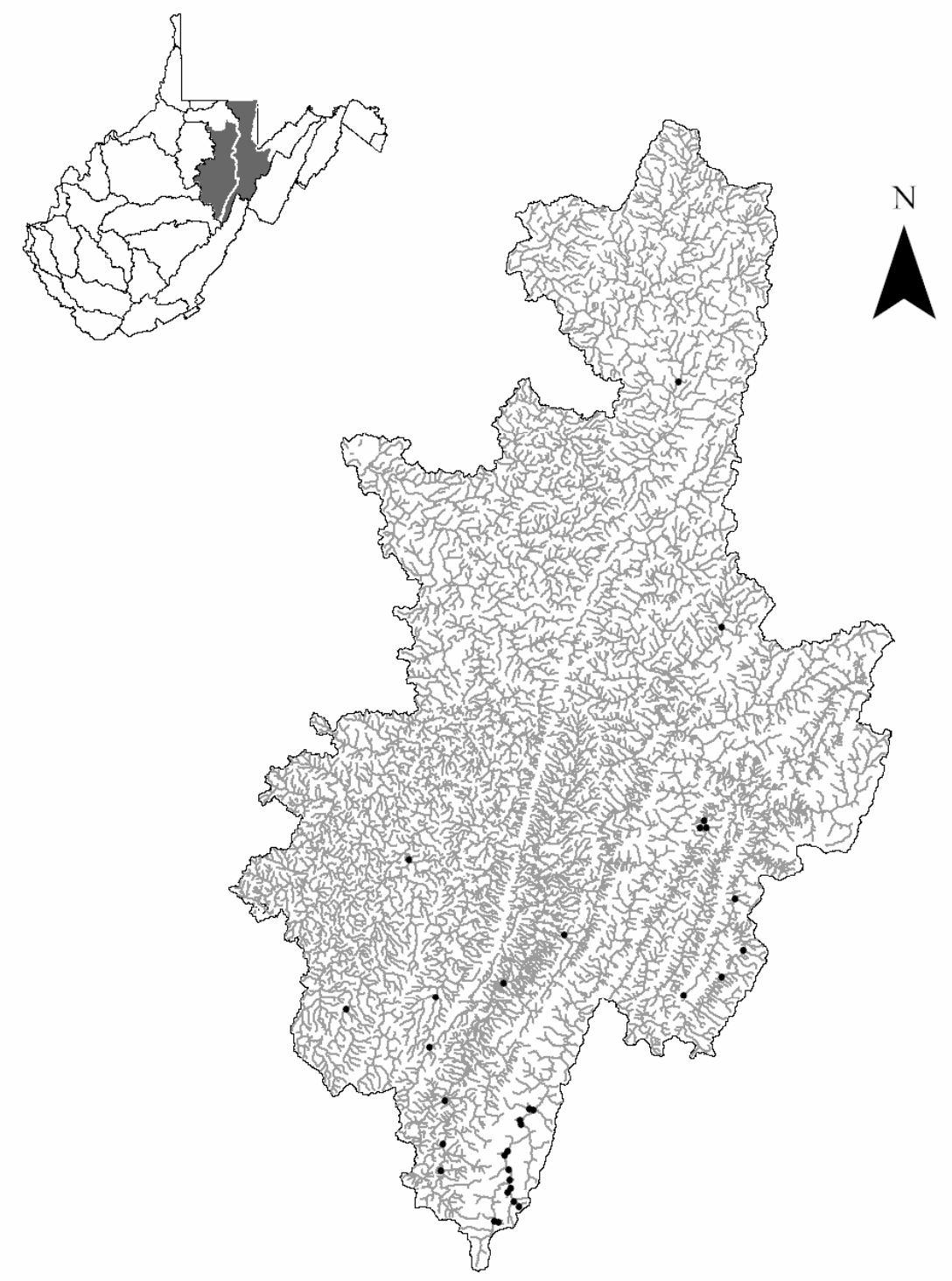

$0 \quad 1020 \quad 40$ Kilometers

- Sites sampled

Figure 1.- - Locations of sampled sites within the Cheat River and Tygart Valley River watersheds of West Virginia. 


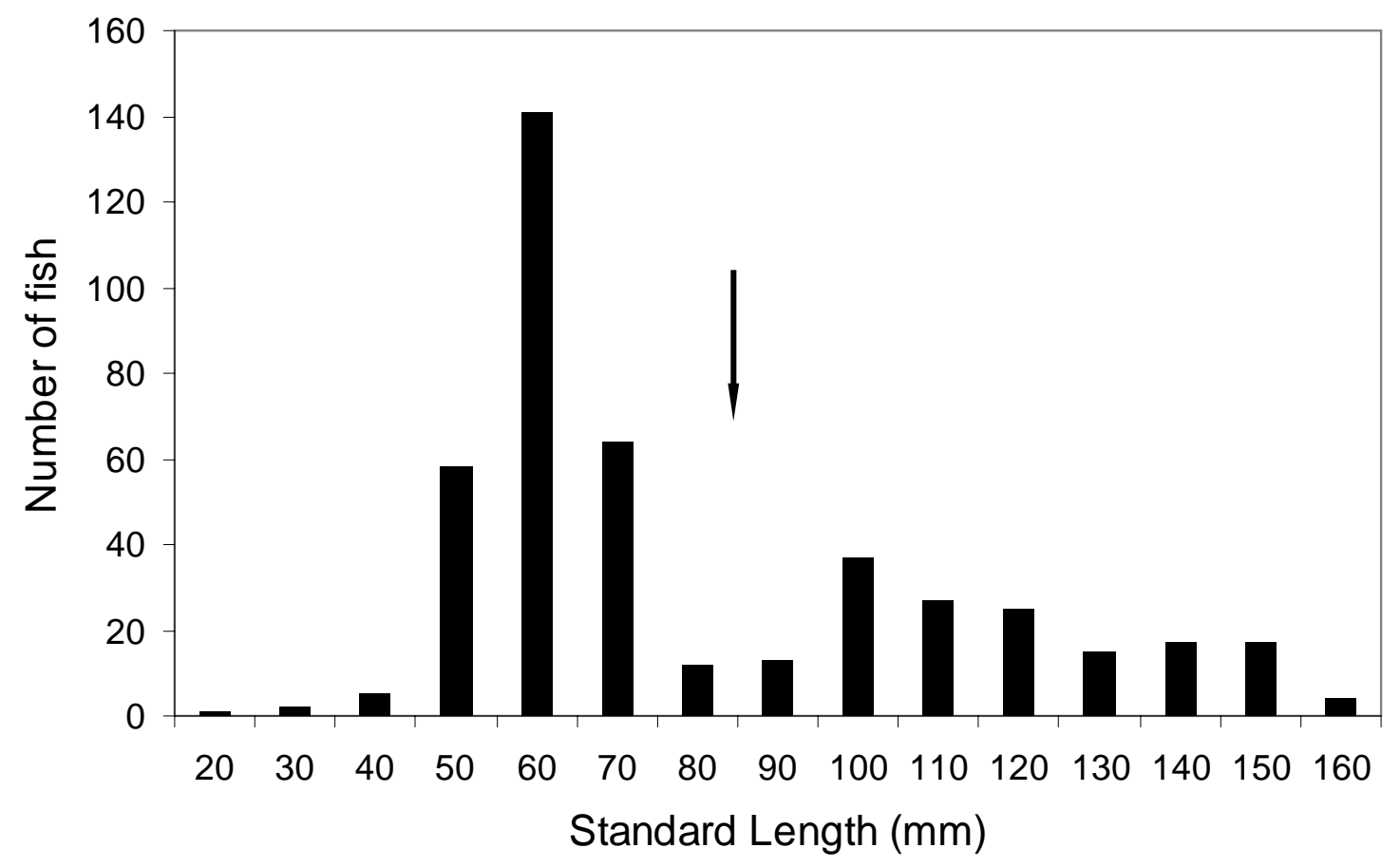

Figure 2.-An example of the length frequency histograms used to determine juvenile and adult age cutoffs. The example shown is for brook trout captured in summer 2005. 

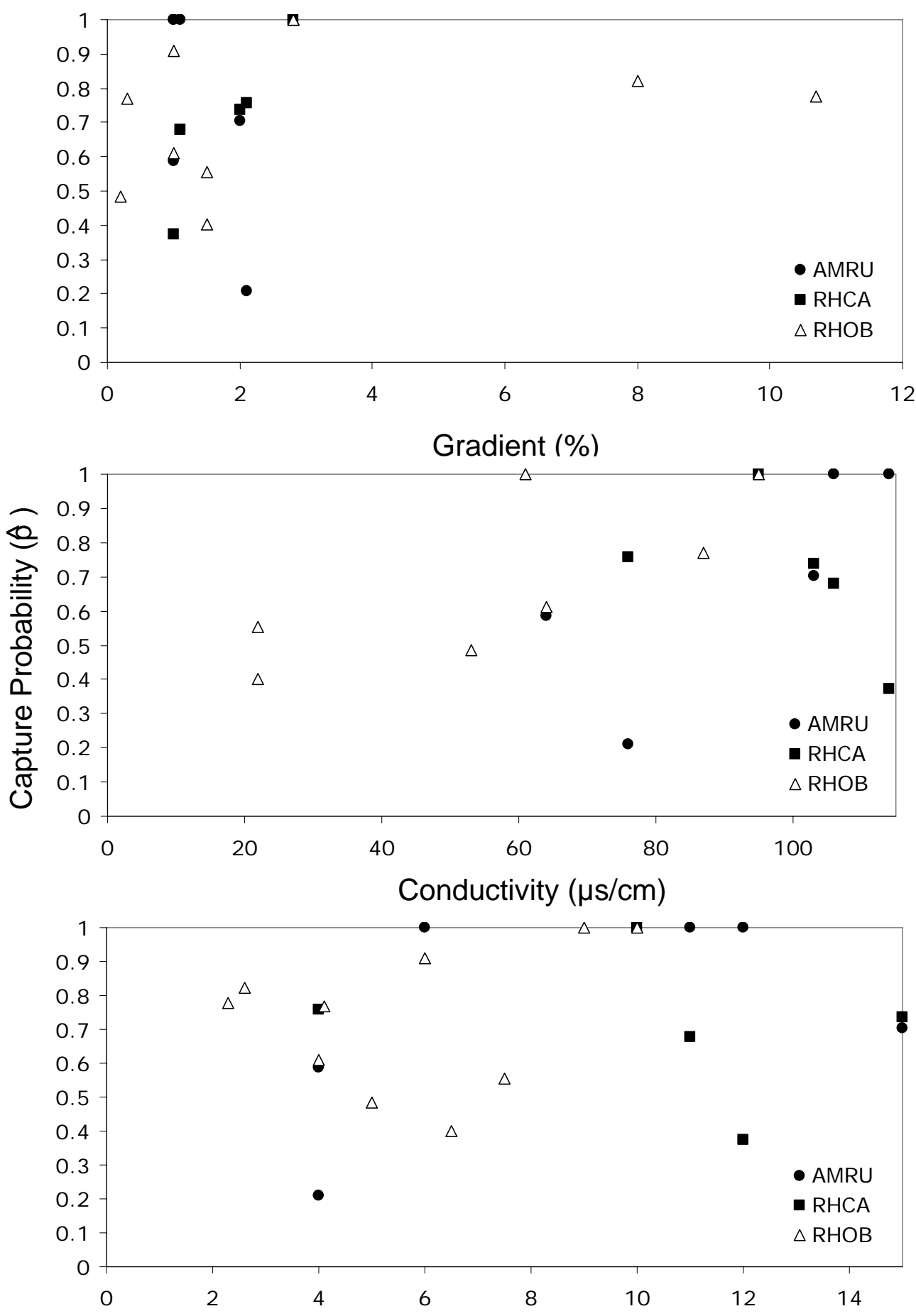

Mean Stream Width (m)

Figure 3.- Relationships between physico-chemical variables and observed capture probabilities at sites sampled for species/size classes that we were able to construct significant models to predict capture efficiency. Increasing conductivity is most positively related towi capture probability. 


\title{
Chapter 2
}

Juvenile and Adult Fish Distributions Along a Central Appalachian Stream Size Continuum: A Watershed Scale View of Reproductive and Post-Reproductive Influences on Fish Assemblages

\begin{abstract}
The value of using watershed scale studies to understand stream fish population and assemblage dynamics is increasingly well recognized. Stream fish reproduction, growth, survivorship, and dispersal are influenced by numerous processes operating across multiple scales. However, very little is known about watershed scale distributions of most fish species. Consequently, we sampled fish communities in two Appalachian watersheds across a range of stream sizes $\left(1^{\text {st }}\right.$ to $5^{\text {th }}$ Strahler Order $)$ to quantify the watershed scale distribution patterns of juveniles and adults of 14 species common to this region. A total of 47 sites were sampled ranging from 0.1 to $125 \mathrm{~km}^{2}$ drainage area, and within each site we estimated the abundance of juvenile and adult age classes. We found that 27 of the 28 species and age groups were non-uniformly distributed across the range of stream sizes sampled. This analysis enabled us to classify each species as being either ubiquitous (mottled sculpin, green sunfish adults) small stream centered (brook trout, blacknose dace, green sunfish juveniles, creek chub), intermediate size stream centered (white sucker, rosyside dace, fantail darter, longnose dace), or large stream centered (central stoneroller, northern hogsucker, rock bass, smallmouth bass, river chub). Our analyses also determined that there was considerable variation in the degree of overlap in the distribution of juveniles and adults of the same species. The spatial distribution of juveniles and adults of several species were highly correlated, suggesting that the broad distributional pattern of these species is dependent on processes that determine reproductive success. In contrast, the juveniles of several other species were distributed
\end{abstract}


as a small subset of the adult distributions, suggesting that post-reproductive processes (e.g., dispersal and mortality) may be more important in structuring the watershed scale organization of these species. These results indicate that reproduction and postreproductive processes interact to determine population and community level organization of stream fishes at a watershed scale. Consequently, additional descriptive and experimental studies are needed at this scale to ensure successful conservation of Appalachian stream fishes. 


\section{Introduction}

Aquatic systems operate at multiple scales, from spaces of a few centimeters to global processes. The stream network is a series of interrelated relationships. In-stream habitat is determined by a number of factors that can be as general as weather patterns, underlying geomorphology and elevation, or as specific as gradients of substrate and cover available within a stream segment. Watersheds function on these multiple levels across space and time (Angermeier and Winston 1989). Stream fish populations operate within these systems, but we do not know which scale of focus, local or regional, determines their distributions and influences life history. Lotic systems contain nested hierarchies that are essentially heterogeneous patches within patches (Torgersen et al. 2006). For researchers or managers to ignore scale is a problem (Dunham and Vinyard 1997); the multi-scale spatial heterogeneity of stream networks affects the patterns and processes of populations at each step (Lowe et al. 2006).

Historically there has been a focus on identifying how fish populations are governed by micro- and mesohabitat scale processes. Studies of local factors have several advantages over regional factors. Local variables are easier to measure, identify, and correlate with fish abundances and distributions than are regional factors (Jackson and Harvey 1989). Work on the individual stream reach or unit has produced ideas about how organisms operate locally with regard to distribution and demographics (Hanski 1999). Studies have related local fish structure to stream habitat, such as Meffe and Sheldon (1988), who related site-to-site variation in fish assemblages to local habitat, velocity and size. Small-scale predator-prey interactions and competition have been 
explored. Werner and Hall (1977) observed that within-pond sunfish competition led bluegill to a feeding shift.

Local patch movement has been explored as well (Hill and Grossman 1993; Petty and Grossman 1996). The idea that stream fishes are altogether limited in mobility (Gerking 1953), has sparked many small-scale movement examinations, under the assumption that fishes are confined to operating at a smaller scale (Freeman 1995; Petty and Grossman 1996). However, revelations in stream fish movement (Gowan and Fausch 1996), and examinations of scale-dependent processes (Fausch et al. 2002) have led to increased awareness of the importance of larger watershed-scale processes. Some stream fishes show evidence of greater mobility that is prompted by larger-scale processes, and researchers are questioning the ability of local structures and functions to inform the processes occurring at broader scales (Magalhaes et al.2002).

In 1989, Wiens referred to scale as the new "ecological buzzword," and in the past few decades there has been a shift in scale awareness as larger watershed-scale processes are explored in relation to fish dynamics and distributions (Schlosser and Kallemeyn 2000). Scale determines the amount of spatial heterogeneity and patchiness observed in an area. The spatial arrangement of patches for spawning, rearing, feeding, and refuge habitat for different organisms as they complete their life history must be examined (Dunning et al. 1992). Space and time affect taxa at different scales in the form of dynamic patch structure, patch quality, connectivity of patches, and barriers to movement (Schlosser and Kallemyn 2000). Not all factors bear the same influence at all scales. Examination of populations at the watershed scale provides a continuous picture of how stream fishes operate across a system as opposed to snapshots of organization 
within individual stream reaches (Fausch et al. 2002). Watershed-scale models produce coarser abundance estimates, but generally relatable information is more valuable than detailed data collected irrelevant to the processes of interest (Fausch et al. 2002).

Several recent studies have examined how watershed processes influence fish assemblages. Schlosser (1995) and Snodgrass (1997) observed that beaver ponds change the diversity and dynamics of populations across a landscape. Snodgrass documented that beaver ponds impounded streams and affected the interaction of habitat patches and organism diversity on a larger scale. Schlosser's study showed that beaver ponds controlled dispersal, thereby affecting fish assemblage both upstream and downstream from the ponds. Upstream and downstream directional interactions were also observed by Osborne and Wiley (1992), who examined the impact of stream position in a drainage network, rather than an upstream to downstream only direction. Different taxa relate to the environment in different ways, because they experience different life histories. For some species, dispersal can be more important than local biotic and abiotic factors (Schlosser 1991).

Salmonids have been the focus of most watershed-scale studies. Hughes' (1999) research on arctic grayling showed age-phased and growth-dependent movement in a single population distributed along an entire length of river. Within the grayling population, there was a sorting of the fast growing and older fish upriver, and the slow growing and younger fish downriver. Rich et al. (2003) found that large-scale models predicted bull trout distribution better than local factors alone. These watershed-scale studies provide new and valuable information regarding the impact of life history on stream fish distributions at a regional level. Rieman and Dunham (2000) considered the 
life history of salmonids, relating metapopulation models to watershed distributions because of the discreteness of spawning and rearing habitat. They recognized that the dynamics of spatial distribution and dispersal were neither simple nor consistent across species and watersheds. Petty et al. (2005) quantified the watershed-scale distribution patterns of brook trout in a $32 \mathrm{~km}^{2}$ watershed and identified that small headwater streams were important for reproduction, while large adults were downstream. They quantified the relative importance of reproductive processes (spawning and juvenile recruitment) and post-reproductive processes (mortality and dispersal) on brook trout distributions across the watershed. Such information provides strategies for restoration and conservation at the watershed scale. For example, brook trout conservation efforts may focus on restoring headwaters where reproduction occurs, or reconnecting the headwater tributaries with larger mainstems.

Watershed-scale information provides a different and more powerful view of habitat requirements and conservation information for many species than do local studies. Local attributes such as hydrologic units of pool or riffle species can predict in-stream abundance, but do not predict distributions extending beyond the sampled sites. The sums of local information will not equal the patterns observed across the watershed. To recognize population dynamics on an appropriate scale, and population responses to changes in the landscape, understanding of the greater interrelatedness of spatial patches is required (Dunning et al. 1992).

Currently there are no watershed-scale studies of distribution for most stream fishes. The geographic distributions and taxonomies of most stream fishes are known, but it remains to be seen how these function in the variety of landscapes in which they 
exist (Angermeier and Winston 1998). With the exception of some recent salmonid studies (Rieman and McIntyre 1995; Rieman and Dunham 2003; Petty et al. 2005), limitations in the watershed-scale knowledge of stream fishes impairs the ability of researchers and managers to predict outcomes or identify risks from landscape changes to most species (Jackson and Harvey 1989). A few studies have found evidence that a watershed view is pertinent for fishes other than salmonids. Magalhaes et al. (2002) found that Mediterranean stream fishes may not be distributed in proportion to local physical environment, but instead reflect landscape patches and dispersal. In the Midwest, stream fish assemblages were explained almost entirely by large-scale factors rather than within-stream characteristics (Marsh-Matthews and Matthews 2000). These studies are evidence that regardless of family or location, all species are guided by the major life history events of reproduction, dispersal and mortality. It is the time, scope, and scale of how these life history events interact with the physical environment that informs the population scale (Schlosser and Ebel 1989). Moving watershed scale studies beyond salmonids is important because spatial patterns and processes most likely influence a range of taxa, but the respective responses may vary by species and age (Rieman and McIntyre 1995).

\section{Objectives}

The overriding objective of this research was to gain a better understanding of the spatial structure of stream fish distributions at a watershed scale. Specifically, we addressed the following objectives: 
1. Quantify the watershed-scale distributional patterns of fish species common to the central Appalachian region as they relate to stream basin area (i.e. stream position along a size gradient);

2. Determine whether or not there is strong overlap in the distributions of juvenile and adult size classes;

3. Classify each species with regard to its overall distributional pattern and the degree to which juvenile and adult distributions overlap;

\section{Methods}

Study area

We conducted our study during the summers of 2004-2005 in the Cheat River and Tygart Valley River watersheds in the Monongahela River basin (Figure 1). The Cheat River watershed drains approximately $3,700 \mathrm{~km}^{2}$ and is formed by the confluence of the Shavers and Black Forks at Parsons, WV. The Tygart Valley River watershed contains $3,522 \mathrm{~km}^{2}$ of drainage. The land cover on these watersheds is predominantly forested with interspersed patches of low intensity pasture-based agriculture and residential centers. Although portions of both watersheds are impacted by acid mine drainage, our study area was concentrated in the upper segments of the watersheds where mining is rare and many high quality streams persist (Freund 2004). These upper portions of the watersheds provide some of the best approximations of intact fluvial systems available in the eastern US.

Site selection

We studied 47 sites (Table 1) across a range of drainage areas, elevations, and dominant bedrock geologies (sandstone, shale, and limestone). We avoided sampling any areas that were impaired by acid mine drainage or acid precipitation. Basin area ranged 
from $0.6-124.4 \mathrm{~km}^{2}$. Gradient ranged from 0.1 to 20.3 percent. Conductivity ranged from $28-536 \mu \mathrm{s} / \mathrm{cm}$.

\section{Field sampling}

We sampled all sites between July $15^{\text {th }}$ and September $15^{\text {th }}$ in the summers 20042005, when juveniles are large enough to be captured with standard electrofishing methods and equipment (Freund, unpublished data). We sampled streams in a random order to avoid any potential bias from year-to-year variability.

We single-pass backpack electroshocked (Smith Root, DC, $60 \mathrm{hz}, 400-600 \mathrm{~V}$ ) the stream reaches to maximize the scale of sampling (Meador et al. 2003). We selected reaches within the streams that best represented the overall characteristics of the stream. These reaches were located a minimum of $50 \mathrm{~m}$ from the mouth of the stream, a road crossing, or the confluence of a major tributary to avoid potential bias. Following the guidelines of Freund and Petty (2007), reach segments sampled were 40 times mean stream width, with a minimum length of $150 \mathrm{~m}$ and a maximum length of $300 \mathrm{~m}$. Two to four person teams, dependant on stream size, were equipped with backpack shockers (Smith Root, DC, $60 \mathrm{hz}, 400-600 \mathrm{~V})$, dip nets, and a portable seine $($ mesh size $=$ $5 \mathrm{~mm}$ ). Sampling was conducted systematically in an upstream direction.

All fish captured were anesthetized in clove oil (concentration $=40 \mathrm{mg} / \mathrm{L}$ ), measured to standard length $(\mathrm{mm})$, and weighed $(0.01 \mathrm{~g})$.

For each summer of sampling, we separated each species into two size classes, adult and juvenile, based on length frequency distributions of data pooled across the 47 study sites (Figure 2) and compared to published length distinctions (Jenkins \& Burkhead 1994). In sampling we captured rock bass (Ambloplites ruprestris), central stoneroller 
(Campostoma anomalum), white sucker (Catostomus commersoni), rosyside dace (Clinostomus funduloides), mottled sculpin (Cottus bairdi), fantail darter (Etheostoma flabellare), northern hogsucker (Hypentelium nigricans), green sunfish (Lepomis cyanellus) smallmouth bass (Micropterus dolomieu), river chub (Nocomis micropogon), longnose dace (Rhinichthys cataractae), blacknose dace (Rhinichthys obtusus), brook trout (Salvelinus fontinalis), and creek chub (Semotilis atromaculatus) (Table 2). We occasionally encountered yellow bullhead (Amieurus natalis), log perch (Percina caprodes), largemouth bass (Micropterus salmoides), greenside darter (Etheostoma blennioides), rainbow trout (Oncorhynchus mykiss), mountain redbelly dace (Phoxinus oreas), brown trout (Salmo trutta), bluntnose minnow (Pimephales notatus), and several shiner species (Notropis spp.), but not at a large enough number of sampling sites to be included in this study.

Physico-chemical variables.

Numerous variables were measured at each site, including flow, habitat, and chemistry-related factors. Only four variables however are relevant for our analysis here to determine capture probabilities. These included conductivity, stream width, stream gradient, and drainage area. Conductivity was measured on-site $(\mu \mathrm{s} / \mathrm{cm})$ with $600 \mathrm{XL}$ Multi-Parameter Water Quality Monitor (YSI Incorporated, Yellow Springs, Ohio). We measured mean stream width $(\mathrm{m})$ at the time of fish sampling. Gradient was measured with a handheld clinometer $( \pm 1 \%)$. We mapped drainage area for the reachshed with a flow accumulation grid in ArcMap (ESRI 2005). 


\section{Statistical Analyses}

We obtained best estimates of capture probability at each site for species and size class. We based the estimates of capture efficiency on the results of Chapter 1 . In Chapter 1 we used three-pass removal sampling to determine, specific to species and age class, whether each group exhibited constant or variable capture efficiency across sites. We constructed models with stepwise linear regression to relate variability in capture efficiency to site-specific physico-chemical variables (Appendix 2.1). These models of capture were formulated in the same watersheds, using the same sampling techniques as used in this study, thus they are highly applicable to this study. The species and size classes determined to have constant rates of capture were rock bass adults, central stoneroller adults and juveniles, white sucker juveniles, mottled sculpin juveniles, rosyside dace adults, fantail darter adults and juveniles, northern hogsucker adults and juveniles, smallmouth bass juveniles, longnose dace adults, brook trout adults and juveniles and creek chub adults and juveniles. The species and size classes that we were able to construct significant models for included rock bass juveniles, longnose dace juveniles, and blacknose dace adults. We did not have significant models for estimating the capture of rosyside dace juveniles, mottled sculpin adults, and blacknose dace juveniles. The following species were not included in Chapter 1, therefore, we did not have models to estimate capture efficiency for both the adult and juvenile size classes of green sunfish, adult smallmouth bass, and river chub.

We used these models to estimate population size by species and age class for each site. In the absence of either a constant capture efficiency rate, or a model to estimate capture efficiency, we used the actual number caught as the estimate of 
abundance. This would be equivalent to using a constant capture probability. Although we know that capture probability was not constant for these groups, there is no reason to believe that capture efficiency was biased in any way, and the variance is reduced with the scale of the study (Bateman et al. 2005).

Identifying core/periphery areas

Our first objective was to quantify the watershed scale distributional patterns of fish species common to the central Appalachians in relation to stream basin area. We used Freund's (2004) definition of core and periphery fish distributions, which defines the "core" range as the cumulative total frequency between the $25^{\text {th }}$ and $75^{\text {th }}$ percentiles. The peripheral range contained the lower $5^{\text {th }}$ to $25^{\text {th }}$ and the upper $75^{\text {th }}$ to $95^{\text {th }}$ percentile of the total species and size class densities (Figure 3). To identify the core and peripheral range, we sorted the sites by drainage area. We examined the distributions based on the cumulative proportional abundance across sites of increasing basin area. We used abundance increasing across basin area because basin area is generally correlated with species distribution (Sheldon 1968; Angermeier and Schlosser 1989). Basin area also encompasses many physico-chemical factors that affect fish assemblages such as substrate size, flow velocity, stream depth, stream temperature, and canopy cover (Angermeier and Schlosser 1989). To determine if species and size classes were distributed non-randomly across the range of drainage areas sampled, we compared the distributions of juvenile and adult size classes within each species, as well as comparing the study ranges that the species were distributed over. We used a Kolmogorov-Smirnov (KS) goodness of fit test to test the null hypothesis that species and size classes accumulated individuals in direct proportion to linear stream meters accumulated in 
sampling across increasing basin area (Zar 1999). We applied this test to compare juvenile and adult distributions against the expected accumulation across basin area. Overlap in Juvenile and Adult Distributions

Our second objective was to determine whether or not there was strong overlap in the distributions of juvenile and adult size classes. We used a Pearson correlation of the $\log$ abundance values by site to compare the distributions of the size classes to each other. We removed the sites where both size classes were absent to avoid bias in the correlation analysis.

\section{Species Distributional Patterns}

Our third objective was to classify each species with regard to its overall distributional pattern and the degree to which juvenile and adult distributions within species overlap. To determine this, we compared the juvenile and adult distributions to determine the range of overlap within the watershed. We determined the percentage of adult and juvenile shared core range to compare to the uniquely juvenile or adult core range distributions (Figure 4). We also examined the direction each species dispersed when moving from the juvenile core range in the watershed, to the adult core range.

\section{Results}

Non-Uniform Distribution Across Watershed

Data were sufficient for detailed statistical analyses of 14 species (Table 2). Each of those species was included in the analyses based on presence in at least 10 sites. We compared species- and size-specific distributions to an expected accumulation with a KS goodness of fit test, and found that all but green sunfish adult distributions were 
significantly different from our expected cumulative distributions when compared to the critical value at $\alpha=0.05$ (Table 3 ), although there were a few species that were close to the critical value. Consequently, most species and size classes showed non-uniform distributions across the continuum of basin area. We used the calculated relative abundances to get species- and size-specific estimates of the core and periphery ranges. We found wide variation among species and size classes in the basin area ranges of the core distributions of different species (Table 3). Most of the core ranges did not fit the expected distribution, so we categorized the fishes by comparing the core accumulation to the expected accumulation, then categorizing them by the relative size of stream that the core occupied. This was done with a visual inspection of the core range accumulation (Figure 5). Species fit into one of four categories: small-stream core, mid-stream core, large-stream core, and ubiquitous core species. Small stream core species were identified as such because their accumulation in small streams exceeds that of the expected (Figure 5). Small stream core species include brook trout, blacknose dace, green sunfish juveniles, and creek chub. Mid-stream core species werre identified as those species that accumulated more quickly than expected in intermediate stream size basin areas (Figure 5). These fishes included white sucker, rosyside dace, fantail darter, and longnose dace. Large-stream core species accumulated more slowly than expected in the small and intermediate sized streams, but more quickly than expected in the large streams (Figure 5). Large stream core species included central stoneroller, northern hogsucker, rock bass, smallmouth bass, and river chub. Having not been significantly different from the expected distribution, green sunfish adults were classified as ubiquitous. Although mottled sculpin had a distribution significantly different from the expected (Table 3), this 
difference was confined to a few very small streams; consequently, we classified mottled sculpin as ubiquitous because the distributions were very close to uniform in most of the sampled area (Figure 5).

\section{Adult and Juvenile Distribution Correlation}

Smallmouth bass were the only species in our study where the adult and juvenile distributions were not significantly correlated $(r=0.22, p=0.39)($ Table 3$)$. We saw a wide range of correlation in the other species (Figure 6).

Among the significantly correlated distributions, mottled sculpin showed the highest degree of site-to-site correlation in juvenile and adult abundance $(\mathrm{r}=0.88, \mathrm{p}=$ $<0.001)$, whereas white sucker had the lowest correlation $(r=0.41, p=0.03)$. In the abundance correlations, there was a range of site-level distributions displayed, especially when compared to the overlap of juvenile and adult core ranges. White sucker had adult and juvenile core ranges that were very similar to one another, but the lowest degree of site-to-site abundance correlation. Mottled sculpin had the highest significant correlation of the site abundances, and the adult and juvenile core ranges were also closely aligned (Figure 7).

Comparing the abundance correlations within species, we observed three general patterns to site-specific juvenile and adult abundance. Species, such as rosyside dace, fantail darter, northern hogsucker, brook trout, and longnose dace had distributions that included more streams with a presence of adults and a complete absence of juveniles (Figure 6). White sucker, river chub, and small mouth bass were species where there were a number of streams with high juvenile abundances but no adults present. The remaining species, including rock bass, mottled sculpin, green sunfish, blacknose dace, 
creek chub, and central stoneroller tended to have both juveniles and adults present in the same sites.

\section{Within Species Distributional Overlap}

For most species in our study, the juvenile distribution was a subset of the adult distribution across the watershed. To examine the relationship of juvenile and adult distributions at this scale, we compared both the amount of overlap in the juvenile and adult within-species ranges to the amount of non-overlapping, or uniquely adult or uniquely juvenile range (Figure 8). We found that the species fell into four general quadrants of juvenile/adult distributional overlap and instituted classifications based on the proportion of overlap. A majority of the species in our study had high overlap (Figure 8). These species included white sucker, creek chub, river chub, rosyside dace, longnose dace, rock bass, and mottled sculpin. Species that did not have as much of an overlap, but for which juveniles were a subset of the adult population included green sunfish, smallmouth bass, northern hogsucker, and brook trout. Fantail darter was the only species classified as low overlap (i.e. the adult and juvenile populations were highly offset. Central stoneroller was an exceptional species in that it was the only species where the adult population was a subset of the juvenile population (Figure 8).

We also examined the direction of the species expansion from juvenile to adult distributions (Figure 8). Among the species that had significantly different adult and juvenile distributions, there were four patterns. Some species expanded from upstream to downstream. These species included brook trout, green sunfish, and northern hogsucker These fishes were all within the juvenile subset of adult quadrant (Figure 8). The majority of species expanded from downstream to upstream. These species were white 
sucker, mottled sculpin, creek chub, rock bass, fantail darter, blacknose dace, and longnose dace. Excluding the fantail darter, these species were in the high overlap quadrant. Species that expanded outward from a midstream juvenile base were rosyside dace, river chub, and smallmouth bass. Central stoneroller was the only species that contracted its range. There were also slight patterns within the fishes that did not have significant differences between adult and juvenile distributions, although the populations were much more closely matched (Figure 8).

\section{Discussion}

Stream size across the watershed revealed a great deal about the distributions and interactions of size classes and species within the watersheds. While there are many studies that advocate large-scale examinations of stream fish distributions (Schlosser 1991; Fausch et al. 2002; Bateman et al. 2005), with the exception of brook trout, Appalachian stream fishes are largely neglected in previous research at this scale. Petty et al. (2005) quantified brook trout juvenile, small and large adult distributions in a watershed. Torgersen and Close (2004) examined the larval and juvenile distributions of brook lamprey. Fausch et al. (2002) emphasized the importance of riverscape study to appreciate the full impact of the surrounding landscape on populations. This study is somewhat unique in identifying the distributional relationships of several species in an area on a species level. Pusey et al. (2000), in a watershed-scale assessment of fish assemblage, argued that knowledge on a species level would be more profitable to research and management because of differential responses of speciesBeyond the guilds and assemblages of species and ages, there are likely more patterns and processes to be recognized at this level (Torgersen et al. 2006). Generally though, these studies have 
noted the necessity of large-scale examination of species and distributions to more fully appreciate the contributions of historic, current, geographic, local, biotic and abiotic factors on lotic populations.

The importance of stream size and drainage area characteristics to fish communities is documented at all scales of fish research. Fish assemblages are regionally aligned by hydrologic regime (Meffe and Sheldon 1988; Poff and Allan 1995; Marchetti and Moyle 2001), which is influenced on the large scale by the history, structure, and geographic context of the watershed. We found wide variation in the core distributions of juveniles and adults among the various species. While we found representatives of most species across the entire sampled range, the core distributions of most species were specific to a certain range within the watersheds. We identified only two species as uniform in their distributions, mottled sculpin and green sunfish adults. Most of the species did not follow the expected accumulation, but instead occupied core regions that we identified as small, intermediate and large stream cores. This indicates that within their geographic range, these fishes are not just arranged preferentially with regard to instream habitat, but also across the scale of the region they occupy. We classified the species and size classes by stream size instead of attempting to link them to microhabitat features because the patterns of the larger scale influence the smaller scale in terms of evolution, origin, thermal regimes, geographic placement, distribution, colonization and regional distributions (Pusey et al. 2000). Many of the small scale factors are dampened or eliminated at the watershed scale (Hitt and Angermeier 1986), and often factors that are significant at the larger scale may be nonsignificant at smaller scales (Torgersen and Close 2004). 
Much research has been devoted to showing how species accumulate in a watershed. Schlosser and Angermeier (1989) showed that species richness increased as stream width and volume increased. The availability of adjacent streams also increases richness (Osborne and Wiley 1992). Torgersen et al. (2006) noted that species respond differently to longitudinal variations in the network, because corresponding habitat changes are nonlinear and very complex. In examining the accumulation of species across the watersheds, we observed stream size-related accumulation and loss of core distributions among fish in our study. We saw that as stream size increased from headwater to larger streams, we quickly accumulated a number of species' core areas of distributions, up to about $40 \mathrm{~km}^{2}$ streams. This stream size/fish species accumulation partly reflects what Schlosser and Angermeier observed (1989). The core areas for the majority of fishes in our study were centered in streams sized $10 \mathrm{~km}^{2}-40 \mathrm{~km}^{2}$. Streams that were $50 \mathrm{~km}^{2}$ and larger contained the cores of the large-stream species, but just the peripheries of the other species. All of the species in the study accumulated to core abundances in streams smaller than $90 \mathrm{~km}^{2}$. This is probably a reflection of both the sampling constrictions and the area of study.

The importance of scale to this study became evident when we compared the species' juvenile and adult site correlation and the range overlap. Occasionally there were discrepancies between the correlation values and the overlap for the ranges over which the adult and juvenile cores were distributed. White sucker is an example, with a correlation of 0.4 , but the actual ranges of juvenile and adult core distributions were highly overlapped. The low correlation is because we found juvenile white suckers in 20 streams, but found adults in only 10 streams. Most of the streams with juveniles had no 
adults (16 of 20), although these streams had low number of juveniles, typically less than 10 individual fish at most of these sites. The sites that had both adults and juveniles had the largest proportions of total abundances of fish of both size classes (over 50 individual juveniles). Examining the extent of the adult and juvenile core ranges relative to basin area, across the range of the watershed, adult and juvenile white suckers are occupying the same size streams. Mottled sculpin had a much higher abundance correlation, but the actual core range overlap was not as high as the white sucker. Features that determine abundance at the local level do not necessarily dictate positions and densities of fishes regionally (Hitt and Angermeier 1989). With these two fishes we might detect local abiotic and biotic habitat differences that are not being shown regionally. Microhabitat variables are not always successful in predicting fish presence or abundance (Petty and Grossman 1996; Torgersen et al.2006), especially without a larger context of a standing stock (Bozek and Rahel 1991). Fishes can shift microhabitat-correlated abundances quickly in the presence of inter- and intra- specific competition (Torgersen et al. 2006), whereas movement across the watershed in response to the same variables may not happen as quickly.

The juvenile and adult core distributions were highly overlapped for most species in our study. This suggests that the broad distributions of these species may be highly dependent on processes that determine reproductive success. The juveniles and adults of these species, such as mottled sculpin and creek chub, were found in the same areas of the watershed, and so species as a whole are not exposed to the complications of traversing through multiple habitats, flow regimes, physico-chemical factors, and potential barriers as are species whose juvenile and adult populations are more separate. 
This idea is supported by studies that document how some species, like mottled sculpin, have populations that are strongly density dependent and governed by small-scale processes (Grossman et al. 2005). In contrast, some species' adult and juvenile core ranges were not as highly correlated, like brook trout, where the juvenile distributions were a subset of the adult distributions. This disjuncture suggests that post-reproductive processes such as dispersal and mortality may be more important in structuring the watershed scale organization of these species. The segregation between juvenile and adult distributions introduces greater variability into the species' life history, which makes the distribution more highly influenced by post- reproductive processes including immigration/emigration and mortality (Angermeier and Schlosser 1989). Additional evidence of this was provided by Petty et al. (2005). They observed that these postreproductive processes are what determined the distribution of brook trout in a small watershed. The juvenile distribution was highly concentrated year-to-year in streams $<3$ $\mathrm{km}^{2}$ whereas the adult distribution was more widely spread across the watershed and varied according to physico-chemical habitat and not juvenile survivorship.

\section{Management Implications}

This watershed-scale view of the juvenile and adult distributions of Appalachian stream fishes is important for research, conservation, management, and restoration. Conservation efforts requires prior knowledge of fish distribution and habitat use by individual species and size classes, and aside from basic geographic ranges, the watershed distributions for non-game fishes are poorly documented (Porter et al. 2000). In order to maximize benefit for cost, restoration projects should be designed on the watershed scale (Ziemer 1997). Lotic systems are networks, and cannot be functionally 
divided; therefore protection of part of the system means protection of the entire system (Angermeier and Winston 1998). For example, treating acidity in headwater streams will maximize reproduction as stream alkalinity affects brook trout reproduction and these then brook trout recruit downstream with age, thus utilizing more of the watershed (Petty et al. 2005). We found that for many of the fishes in our study, adult and juvenile distributions had some degree of correlation, but range and site overlap may not correspond. This disjuncture implies some type of mobility. Also, the offset in core range between juveniles and adults may be indicative of some type of movement. And some of these fishes have already been associated with movement. Appalachian brook trout dispersal of large adults downstream was observed in Petty et al. (2005). Roberts and Angermeier (2006) found adult fantail darter movement in an upstream direction during the post spawning summer months. Mundahl and Ingersoll (1983) also observed this upstream movement by the adult fantail darter and estimated that its movement occurredon a larger scale than other darter species. We found that the offset of juvenile and adult distributions occurred in both an upstream and downstream direction. Osborne and Wiley's (1992) and Schlosser's (1995) study of beaver dams found bi-directional movement in fish populations across the region. These dispersal and movement routes must be protected (Lowe 2002; Fagan 2002) because localized barriers may affect the entire system. Barriers such as dams and culverts can separate juvenile and adult cores, which have different degrees of overlap for different species, and this isolation can decimate a population. Prior knowledge of intact systems and their patterns and processes is necessary to detect and monitor watershed scale impairment (Frissell and Ralph 1999). 
To the best of our knowledge, our study is the first to examine core distributions of juvenile and adult temperate stream fishes on the watershed scale for most of the fishes in this study. Our sampling included a large number of sites, and we adjusted abundance with capture efficiency modeled specifically for the species, sizes, and watersheds. There are some aspects of this study that future studies should address. This study was short term, encompassing data from two summers only, and we were not able to examine any year-to-year variability in core ranges, especially of juveniles. Previous studies have indicated that juvenile abundance may vary highly from year to year (Petty et al. 2005). This study was comprised of wadeable streams only, and so core ranges, especially for large- stream core species would most likely shift with the addition of the larger streams and rivers in the watersheds. Also, this study does not consider geographic position within the stream network and other distribution patterns, only the position along the watershed continuum. Nevertheless, this study does have application to basic fish ecology. This is additional information about the role of juvenile and adult distributions within population and community dynamics at the watershed scale. 


\section{References}

Angermeier, P.L., and I.J. Schlosser. 1989. Species-area relationship for stream fishes. Ecology 70(5):1450-1462

Angermeier, P.L., and M.R. Winston. 1998. Local vs. regional influences on local diversity in stream fish communities of Virginia. Ecology 79(3):911-927

Bateman, D.S., R.E. Gresswell, and C.E. Torgersen. 2005. Evaluating single-pass catch as a tool for identifying spatial pattern in fish distribution. Journal of Freshwater Ecology 20(2):335-346

Bozek, M.A., and F.J. Rahel. 1991. Assessing habitat requirements of young Colorado River cutthroat trout by use of macrohabitat and microhabitat analyses.

Transactions of the American Fisheries Society 120:571-581

Dunning, J.B., B.J. Danielson, and H.R. Pulliam. 1992. Ecological processes that affect populations in complex landscapes. Oikos 65:169-175

Dunning, J.B., and G.L. Vinyard. 1997. Incorporating stream level variability into analyses of site level fish habitat relationships: some cautionary examples. Transactions of the American Fisheries Society 126:323-329

ESRI (Environmental Systems Research Institute). 2005. ARCGIS, desktop version 9.1. ESRI, Redlands, California.

Fagan, W.F. 2002. Connectivity, fragmentation, and extinction risk in dendritic metapopulations. Ecology 83(12):3243-3249

Fausch, K.D., C.E. Torgersen, C.V. Baxter, and H.W. Li. 2002. Bridging the gap between research and conservation of stream fishes. Bioscience 52(6):483-498

Freeman, M.C. 1995. Movements by two small fish in a large stream. Copeia $2: 361-367$

Freund, J.G. 2004. Local and regional impairment of fish assemblages in a mined Appalachian watershed. Dissertation submitted to the Davis College of Agriculture, Forestry, and Consumer Sciences at West Virginia University.

Freund, J.G., and J.T. Petty. 2007. Response of fish and macroinvertebrate bioindices to specific stressor levels in a mined Appalachian watershed. Environmental Management 00:00-00 (IN PRESS). 
Frissell, C.A., and S.C. Ralph. 1999. Stream and watershed restoration. In Naiman, R.J., and R.E. Bilby. 1999. River Ecology and Management_Lessons from the Pacific Coastal Ecoregion. Springer

Gerking, S.D. 1953. Evidence for the concepts of home range and territory in stream fishes. Ecology 34(2):347-365

Gowan, C., and K.D. Fausch. 1996. Mobile brook trout in two high-elevation Colorado streams: re-evaluating the concept of restricted movement. Canadian Journal of Fisheries and Aquatic Sciences 53:1370-1381

Grossman, G.D., R.E. Ratajczak, J.T. Petty, M.D. Hunter, J.T. Peterson, and G. Grenouillet. Population dynamics of mottled sculpin (Pisces) in a variable environment: Information theoretic approaches. Ecological Monographs 76(2):217-234

Hanski, I. 1999. Habitat connectivity, habitat continuity, and metapopulations in dynamic landscapes. Oikos 87(2):209-219

Hill, J., and G.D. Grossman. 1993. An energetic model of microhabitat use for rainbow trout and rosyside dace. Ecology 74(3):685-698

Hitt, N.P., and P.L. Angermeier. 2006. Effects of adjacent streams on local fish assemblage structure in western Virginia: implications for biomonitoring. American Fisheries Society Symposium 48:75-86

Hughes, N.F. 1999. Population processes responsible for larger-fish-upstream distribution patterns of Arctic grayling (Thymallus arcticus) in interior Alaskan runoff rivers. Canadian Journal of Fisheries and Aquatic Sciences 56:2292-2299

Jackson, D.A., and H.H. Harvey. 1989. Biogeographic associations in fish assemblages: local vs. regional processes. Ecology 70(5):1472-1484

Jenkins, R.E. and N.M. Burkhead. 1994. Freshwater fishes of Virginia. American Fisheries Society, Bethesda, MD.

Lowe, W.H. 2002. Landscape-scale spatial population dynamics in human-impacted stream systems. Environmental Management 30(2):225-233

Magalhaes, M.F., D.C. Batalha, and M.J. Collares-Pereira. 2002. Gradients in stream fish assemblages across a Mediterranean landscape: contributions of environmental factors and spatial structures. Freshwater Biology 47:1015-1031 
Marchetti, M.P., and P.B. Moyle. 2001. Effects of flow regime on fish assemblages in a regulated California stream. Ecological Applications 11(2):530-539

Marsh-Matthews, E., and W.J. Matthews. 2000. Geographic, terrestrial and aquatic factors: which most influence the structure of stream fish assemblages in the Midwestern United States? Ecology of Freshwater Fish 9:9-21

Meador, M.R., J.P. McIntyre, and K.H. Pollock. 2003. Assessing the efficacy of singlepass backpack electrofishing to characterize fish community structure.

Transactions of the American Fisheries Society 132:39-46.

Meffe, G.K., and A.L. Sheldon. 1988. The influence of habitat structure on fish assemblage composition in Southeastern Blackwater streams. American Midland Naturalist 120(2):225-240

Mundahl, N.D. and C.G. Ingersoll. 1983. Early autumn movements and densities of Johnny (Etheostoma nigrum) and fantail (E. flabellare) darters in a southwestern Ohio stream. Ohio Journal of Science. 83(3):103-108.

Osborne, L.L., and M.J. Wiley. 1992. Influence of tributary spatial position on the structure of warmwater fish communities. Canadian Journal of Fisheries and Aquatic Sciences 49:671-681

Petty, J.T., and G.D. Grossman. 1996. Patch selection by mottled sculpin (Pisces: Cottidae) in a southern Appalachian stream. Freshwater Biology 35:261-276

Petty, J.T., P.J. Lamothe, and P.M. Mazik. 2005. Spatial and seasonal dynamics of brook trout populations inhabitat a central Appalachian watershed. Transactions of the American Fisheries Society 134:572-587

Poff, N.L., and J.D. Allan. 1995. Functional organization of stream fish assemblages in relation to hydrological variability. Ecology 76(2):606-627

Porter, M.S., J. Rosenfeld, and E.A. Parkinson. 2000. Predictive models of fish species distribution in the Blackwater drainage, British Columbia. North American Journal of Fisheries Management 20:349-359

Pusey, B.J., M.J. Kennard, and H. Arthington. 2000. Discharge variability and the development of predictive models relating stream fish assemblage structure to habitat in northeastern Australia. Ecology of Freshwater Fish 9:30-50

Rich, C.F., T.E. McMahon, B.E. Rieman, and W.L. Thompson. 2003. Local-habitat, watershed, and biotic features associated with bull trout occurrence in Montana streams. Transaction of the American Fisheries Society 132:1053-1064 
Rieman, B.E., and J.B. Dunham. 2000. Metapopulations and salmonids: a synthesis of life history patterns and empirical observations. Ecology of Freshwater Fish 9:51-64

Rieman, B.E., and J.D. McIntyre. 1995. Occurrence of bull trout in naturally fragmented habitat patches of varied size. Transactions of the American Fisheries Society. 124(3):285-296

Roberts, J.H., and P.L. Angermeier. 2007. Spatiotemporal variability of stream habitat and movement of three species of fish. Population Ecology.

Oecologia 151:417-430.

Schlosser, I.J. 1985. Flow regime, juvenile abundance, and the assemblage structure of stream fishes. Ecology 66(5):1484-1490

Schlosser, I.J. 1995. Dispersal, boundary processes, and trophic-level interactions in streams adjacent to beaver ponds. Ecology 76(3):908-925

Schlosser, I.J. 1991. Stream fish ecology: a landscape perspective. Bioscience 41(10):704-712

Schlosser, I.J., and K.K. Ebel. 1989. Effects of flow regime and cyprinid predation on a headwater stream. Ecological Monographs 59(1):41-57

Schlosser, I.J., and L.W. Kallemeyn. 2000. Spatial variation in fish assemblages across a beaver-influenced successional landscape. Ecology 81(5):1371-1382

Sheldon, A.L. 1968. Species diversity and longitudinal succession in stream fishes. Ecology 49(2):193-198

Snodgrass, J.W. 1997. Temporal and spatial dynamics of beaver-created patches as influenced by management practices in a south-eastern North American landscape. The Journal of Applied Ecology 34(4):1043-1056

Torgersen, C.E., C.V. Baxter, H.W. Li, and B.A. McIntosh. 2006. Landscape influences on longitudinal patterns of river fishes: spatially continuous analysis of fishhabitat relationships. American Fisheries Society Symposium 48:473-492

Torgersen, C.E., and D.A. Close. 2004. Influence of habitat heterogeneity on the distribution of larval Pacific lamprey (Lampetra tridentata) at two spatial scales. Freshwater Biology 49:614-630

Werner, E.E., and D.J. Hall. 1979. Foraging efficiency and habitat switching in competing sunfishes. Ecology 60(2):256-264

Wiens, J.A. 1989. Spatial scaling in ecology. Functional Ecology 3(4):385-397 
Zar, J.H. 1999. Biostatistical Analysis: Fourth Edition. Prentice Hall, Upper Saddle River, New Jersey.

Ziemer, R.R. 1997. Temporal and spatial scales. In Williams, J.E., C.A. Wood, and M.P. Dombeck ed. Watershed restoration: principles and practices. American Fisheries Society, Bethesda, MD 
Table 1.- Summary characteristics of the 47 sites that were sampled in the Cheat River and Tygart Valley River watersheds of WV.

\begin{tabular}{lll}
\hline Stream Characteristics & (Minimum-Maximum) & Mean \\
\hline Basin area $\left(\mathrm{km}^{2}\right)$ & $0.6-124.4$ & 27.9 \\
Mean Stream Width $(\mathrm{m})$ & $1.5-15$ & 4.6 \\
Conductivity $(\mu \mathrm{s} / \mathrm{cm})$ & $28-536$ & 155.4 \\
Gradient $(\%)$ & $0.1-20.3$ & 2.3 \\
\hline
\end{tabular}


Table 2.-Fish included in our analyses, including scientific name, common name, abbreviation, and juvenile/adult size cutoff (standard length). Species are listed in alphabetical order.

\begin{tabular}{lcll}
\hline Species & $\begin{array}{l}\text { Juvenile/Adult } \\
\text { cutoff }(\mathrm{mm})\end{array}$ & Common name & Abbreviation \\
\hline Ambloplites rupestris & 110 & Rock bass & AMRU \\
Campostoma anomalum & 60 & $\begin{array}{l}\text { Central } \\
\text { stoneroller }\end{array}$ & CAAN \\
Catostomus commersoni & & White sucker & CACO \\
Clinostomus funduloides & 180 & Rosyside dace & CLFU \\
Cottus bairdi & 50 & Mottled sculpin & COBA \\
Etheostoma flabellare & 47 & Fantail darter & ETFL \\
Hypentelium nigricans & 33 & Northern & HYNI \\
& 109 & hogsucker & \\
Lepomis cyanellus & & Green sunfish & LECY \\
Micropterus dolomieu & 70 & Smallmouth bass & MIDO \\
Nocomis micropogon & 215 & River chub & NOMI \\
Rhinichthys cataractae & 90 & Longnose dace & RHCA \\
Rhinichthys obtusus & 56 & Blacknose dace & RHOB \\
Salvelinus fontinalis & 44 & Brook trout & SAFO \\
Semotilus atromaculatus & 79 & Creek chub & SEAT \\
& 83 & & \\
\hline
\end{tabular}


Table 3.- Summary of core and periphery distributions by species and size class, sorted by upstream boundary of core range. Edges of core and periphery defined in $\mathrm{km}^{2}$ basin area. The results of the Kolmogorov-Smirnov goodness of fit test between each species and size distribution and the expected (the one nonsignificant value marked with ${ }^{*}$ ), and the coefficient of correlation between the log abundance values for each species are provided.

\begin{tabular}{|c|c|c|c|c|c|c|c|c|}
\hline Species & Age & $\mathrm{N}$ sites & $\begin{array}{l}\mathrm{N} \text { sites } \\
\text { present }\end{array}$ & $\begin{array}{l}\text { Core range } \\
(25 \%-75 \%)\end{array}$ & $\begin{array}{l}\text { Upstream } \\
\text { Periphery }(5 \%)\end{array}$ & $\begin{array}{l}\text { Downstream } \\
\text { Periphery }(95 \%)\end{array}$ & $\mathrm{KS}$ & $\begin{array}{l}\text { Coefficient of } \\
\text { Correlation } \\
\text { (p-value) }\end{array}$ \\
\hline \multirow[t]{2}{*}{ SAFO } & Juvenile & 47 & 12 & $1.7-10.3$ & 0.1 & 24.8 & 0.473 & $0.753(<0.001)$ \\
\hline & Adult & 47 & 17 & $4.7-22.7$ & 0.9 & 38.4 & 0.352 & \\
\hline \multirow[t]{2}{*}{ LECY } & Juvenile & 47 & 16 & $3.1-15.9$ & 2.9 & 120.6 & 0.370 & $0.650(0.001)$ \\
\hline & Adult & 47 & 18 & $3.7-78.9$ & 2.9 & 122.5 & $0.189^{*}$ & \\
\hline \multirow[t]{2}{*}{ SEAT } & Adult & 47 & 36 & $8.7-29.6$ & 3.8 & 42.5 & 0.229 & $0.727(<0.001)$ \\
\hline & Juvenile & 47 & 40 & $9.0-30.3$ & 3.8 & 81.6 & 0.233 & \\
\hline \multirow[t]{2}{*}{ RHOB } & Adult & 45 & 31 & $9.2-26.6$ & 1.3 & 35.9 & 0.306 & $0.675(<0.001)$ \\
\hline & Juvenile & 45 & 30 & $10.2-28.4$ & 3.5 & 49.2 & 0.279 & \\
\hline \multirow[t]{2}{*}{$\mathrm{CACO}$} & Juvenile & 47 & 23 & $9.1-40.2$ & 4.1 & 49.9 & 0.197 & $0.413(0.03)$ \\
\hline & Adult & 47 & 10 & $9.1-39.1$ & 7.1 & 50.8 & 0.202 & \\
\hline \multirow[t]{2}{*}{ COBA } & Adult & 47 & 33 & $10.5-35.5$ & 5.5 & 98.0 & 0.207 & $0.876(<0.001)$ \\
\hline & Juvenile & 47 & 32 & $16.8-49.9$ & 7.6 & 124.2 & 0.215 & \\
\hline \multirow[t]{2}{*}{ RHCA } & Adult & 45 & 17 & $17.2-47.2$ & 10.3 & 101.1 & 0.361 & $0.693(0.002)$ \\
\hline & Juvenile & 45 & 14 & $26.5-49.4$ & 17.2 & 77.8 & 0.472 & \\
\hline \multirow[t]{2}{*}{ CLFU } & Adult & 47 & 11 & $17.3-40.7$ & 10.3 & 43.7 & 0.366 & $0.623(0.04)$ \\
\hline & Juvenile & 47 & 7 & $19.8-36.0$ & 18.2 & 50.5 & 0.441 & \\
\hline \multirow[t]{2}{*}{ ETFL } & Adult & 47 & 21 & $20.3-42.1$ & 17.4 & 111.9 & 0.423 & $0.659(<0.001)$ \\
\hline & Juvenile & 47 & 14 & $37.6-54.2$ & 17.8 & 124.1 & 0.532 & \\
\hline \multirow[t]{2}{*}{ AMRU } & Adult & 45 & 15 & $34.4-104.3$ & 16.5 & 124.0 & 0.444 & $0.502(0.03)$ \\
\hline & Juvenile & 45 & 15 & $50.1-119.0$ & 30.9 & 124.2 & 0.553 & \\
\hline \multirow[t]{2}{*}{ MIDO } & Adult & 47 & 6 & $34.7-124.2$ & 17.0 & 124.4 & 0.480 & $0.217(0.39)$ \\
\hline & Juvenile & 47 & 18 & $48.6-74.4$ & 21.5 & 124.1 & 0.544 & \\
\hline \multirow[t]{2}{*}{ CAAN } & Adult & 47 & 12 & $34.8-51.9$ & 17.1 & 123.2 & 0.421 & $0.609(0.02)$ \\
\hline & Juvenile & 47 & 14 & $35.4-121.0$ & 17.2 & 123.6 & 0.479 & \\
\hline
\end{tabular}


Table 3 continued

\begin{tabular}{lllllllcc}
\hline Species & Age & N sites & $\begin{array}{l}\text { N sites } \\
\text { present }\end{array}$ & $\begin{array}{l}\text { Core range } \\
(25 \%-75 \%)\end{array}$ & $\begin{array}{l}\text { Lower } \\
\text { Periphery }(5 \%)\end{array}$ & $\begin{array}{l}\text { Upper Periphery } \\
(95 \%)\end{array}$ & $\begin{array}{c}\text { KS } \\
(p-v a l u e)\end{array}$ \\
\hline HYNI & Juvenile & 44 & 12 & $38.5-70.8$ & 17.7 & 122.6 & 0.495 & $0.549(0.015)$ \\
& Adult & 44 & 15 & $40.8-101.9$ & 17.3 & 124.2 & 0.533 & \\
\multirow{2}{*}{ NOMI } & Adult & 47 & 9 & $46.5-102.7$ & 36.8 & 124.2 & 0.654 & $0.822(<0.001)$ \\
& Juvenile & 47 & 14 & $53.1-92.0$ & 18.0 & 116.2 & 0.624 & \\
\hline
\end{tabular}



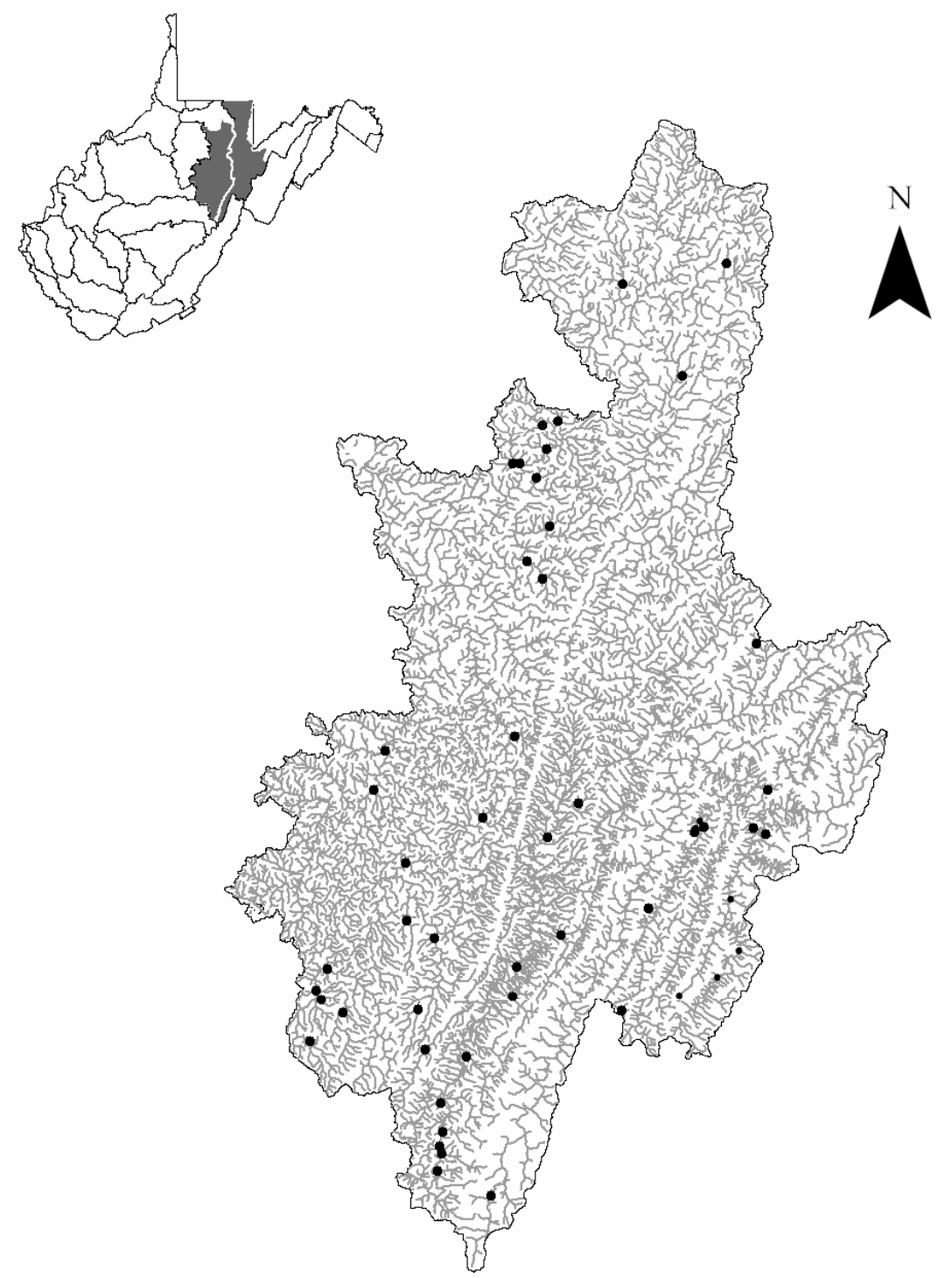

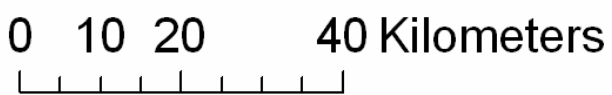

- Sites sampled

Figure 1.-Locations of the sites that were sampled for this study in the Cheat River and Tygart Valley River watersheds of West Virginia. 


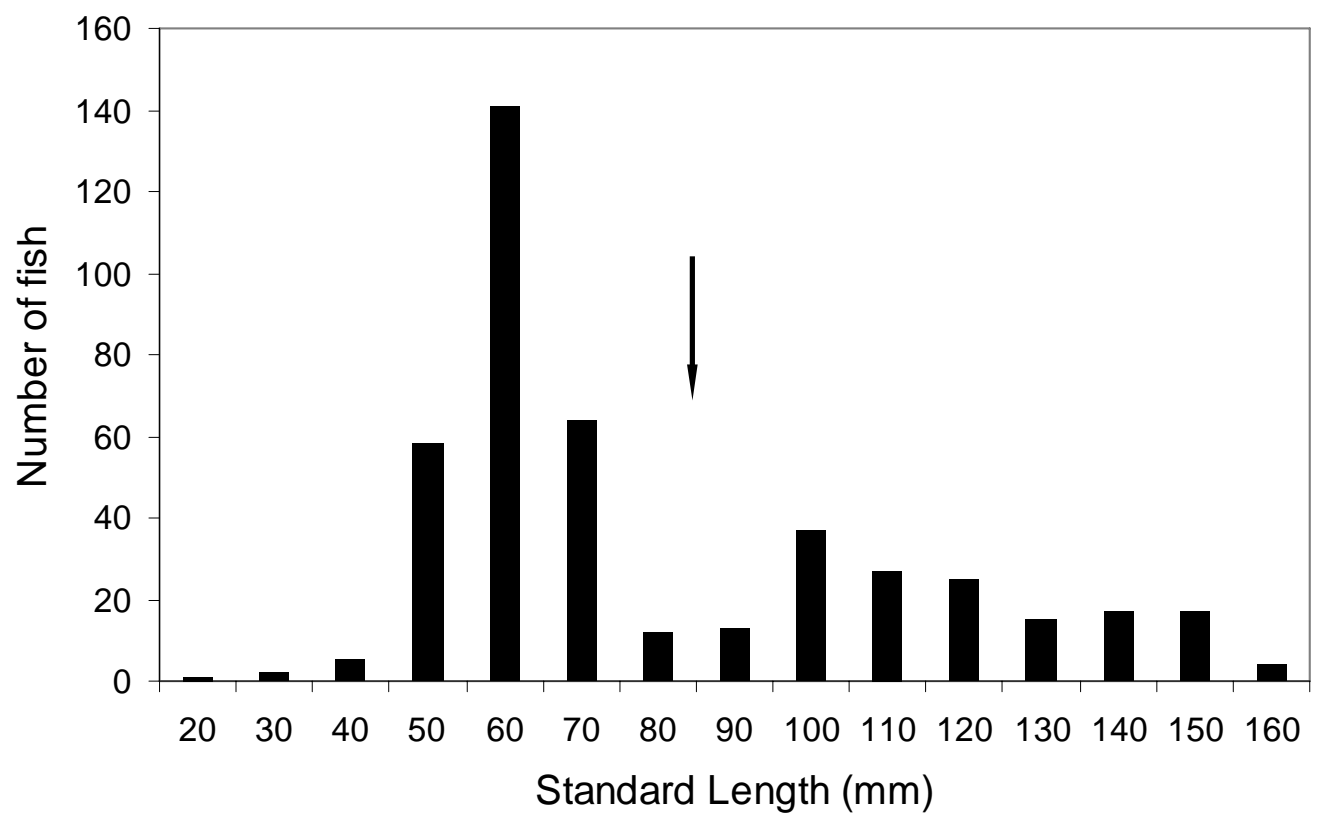

Figure 2.-An example of the length frequency histograms used to determine juvenile and adult age cutoffs. The example shown is for brook trout captured in summer 2005. 


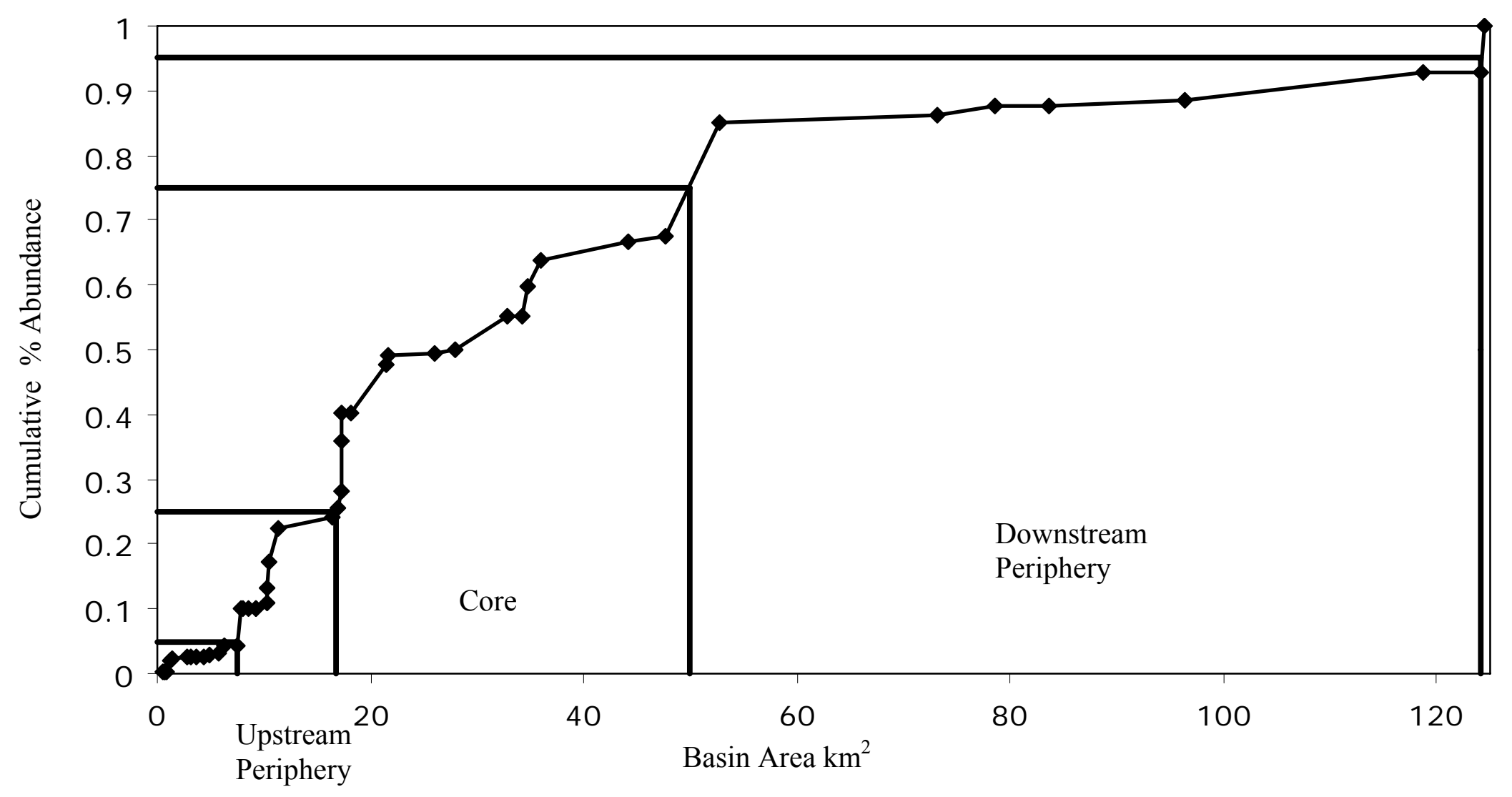

Figure 3.- Example model showing how cumulative percent abundance corresponds to boundaries of lower periphery (L.P.) (5$25 \%)$, core (25-75\%), and upper periphery (75-95\%) associations with basin area sizes of streams sampled. 


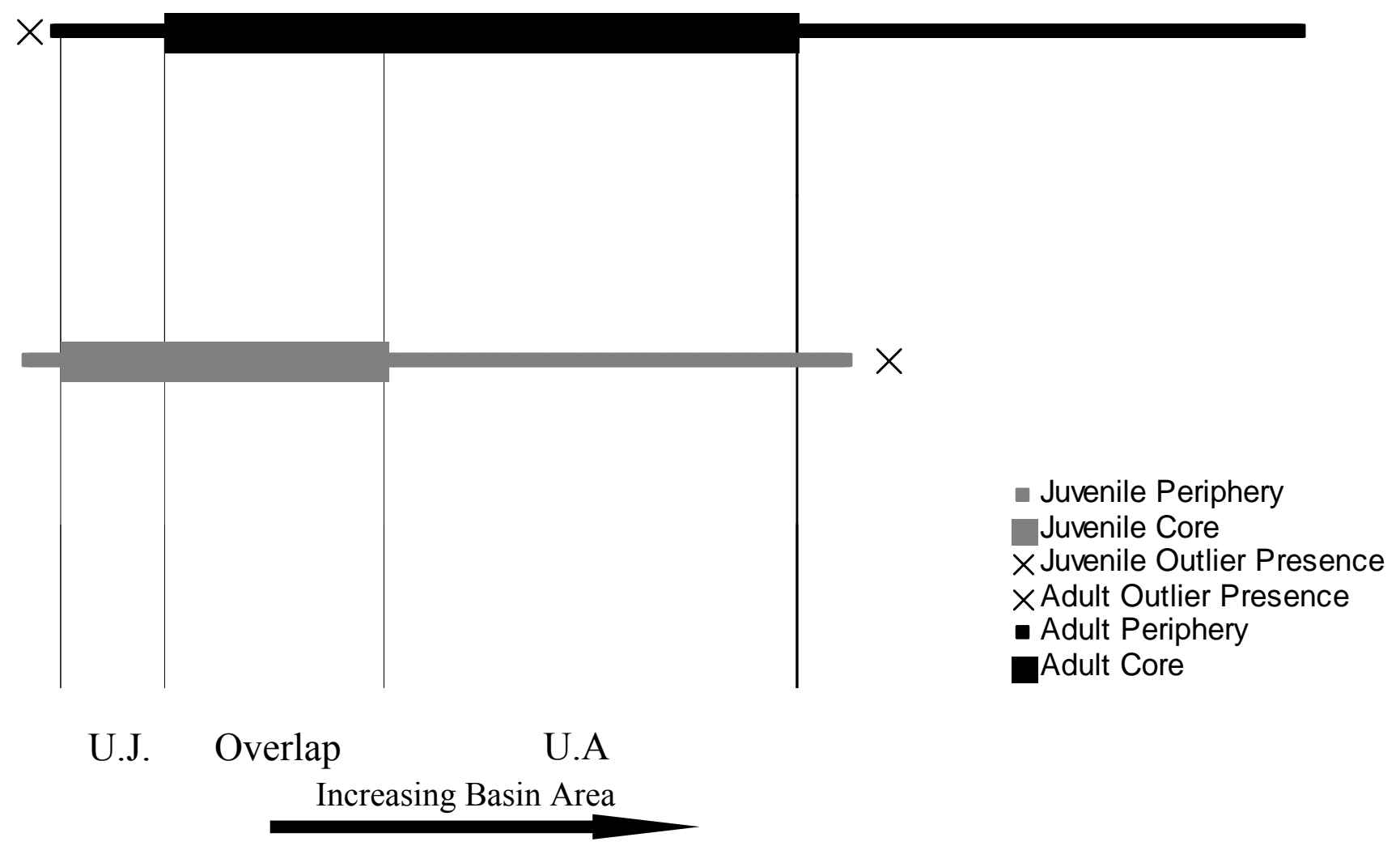

Figure 4.- Example figure showing cumulative distribution of a species across a basin area, and how we calculated range overlap of the adult and juvenile population. The uniquely juvenile (U.J.) space shows where the juvenile core area extends further upstream than does the adult core. The overlap area is the range of basin areas where the adult and juvenile cores overlay each other. The uniquely adult (U.A.) space shows where the adult core range extends further downstream than does the juvenile core range. 

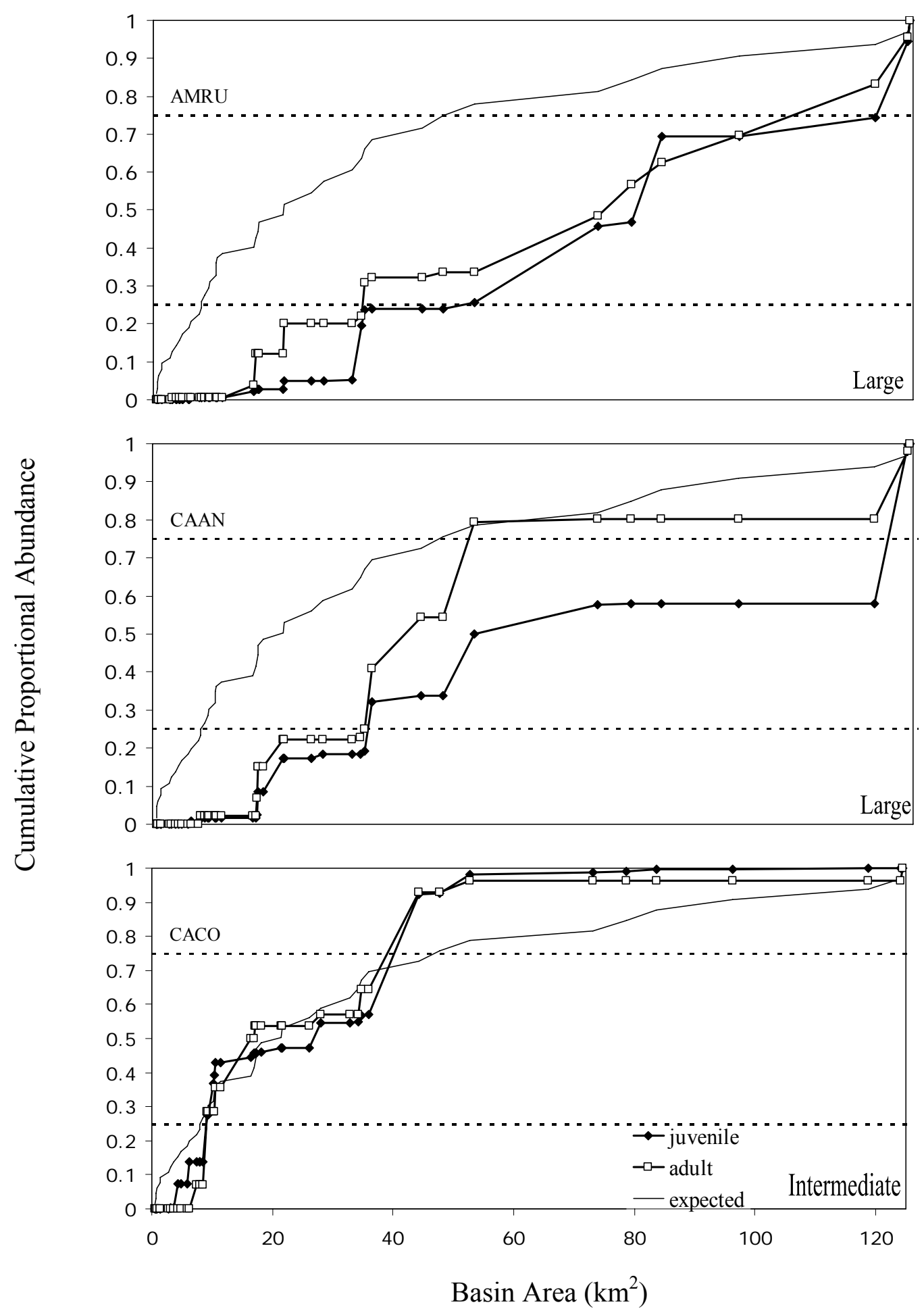

Figure 5.-Cumulative proportional abundances (\% at each site, of total fish sampled), by species, across increasing basin areas. Species are identified as small-, intermediate-, large-, or ubiquitous-core species. Graphs include adult, juvenile, and expected distributions. Core range is marked with broken line. 

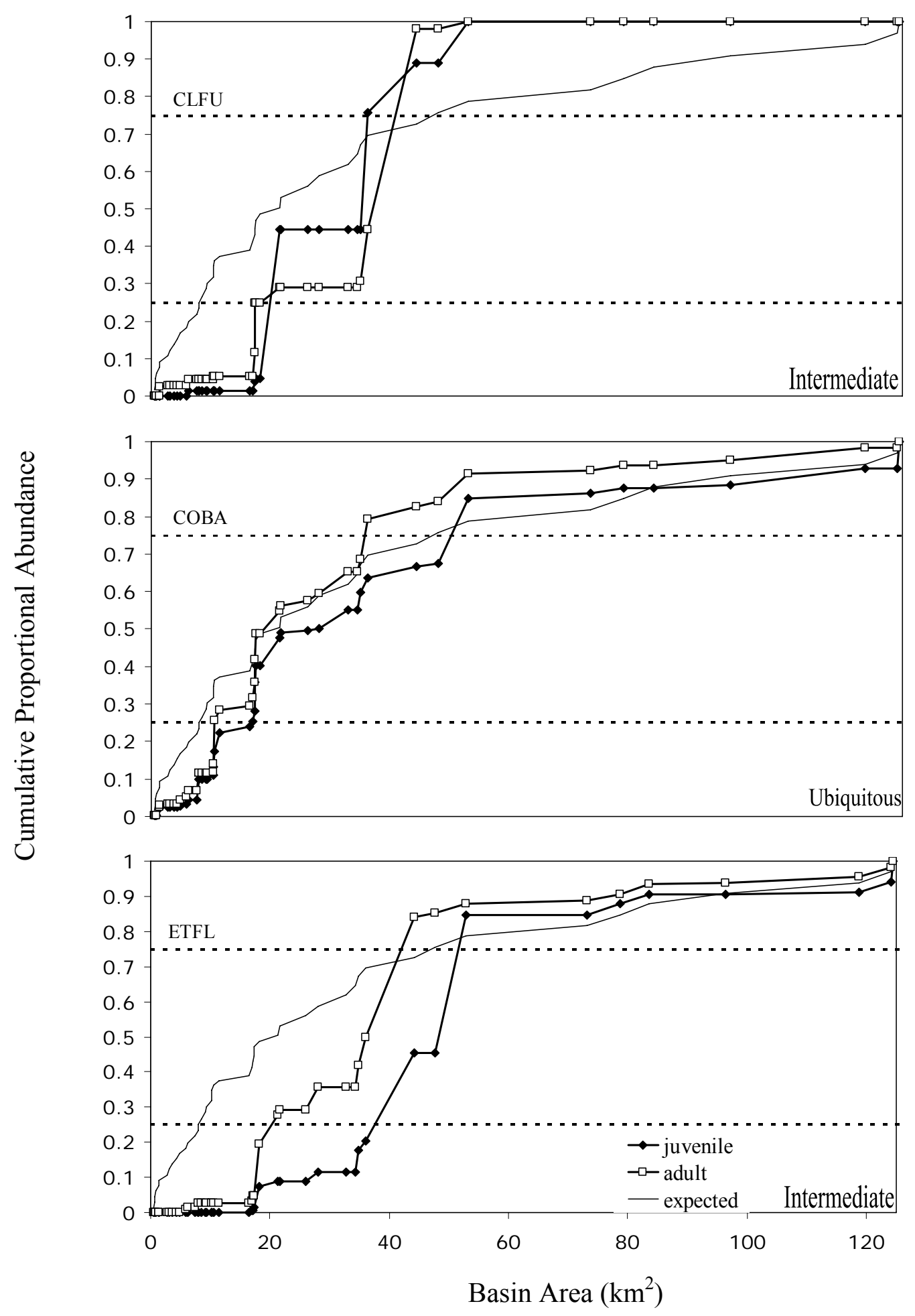

Figure 5.-Continued. Cumulative proportional abundances (\% at each site, of total fish sampled), by species, across increasing basin areas. Species are identified as small-, intermediate-, large-, or ubiquitous-core species. Graphs include adult, juvenile, and expected distributions. Core range is marked with broken line. 

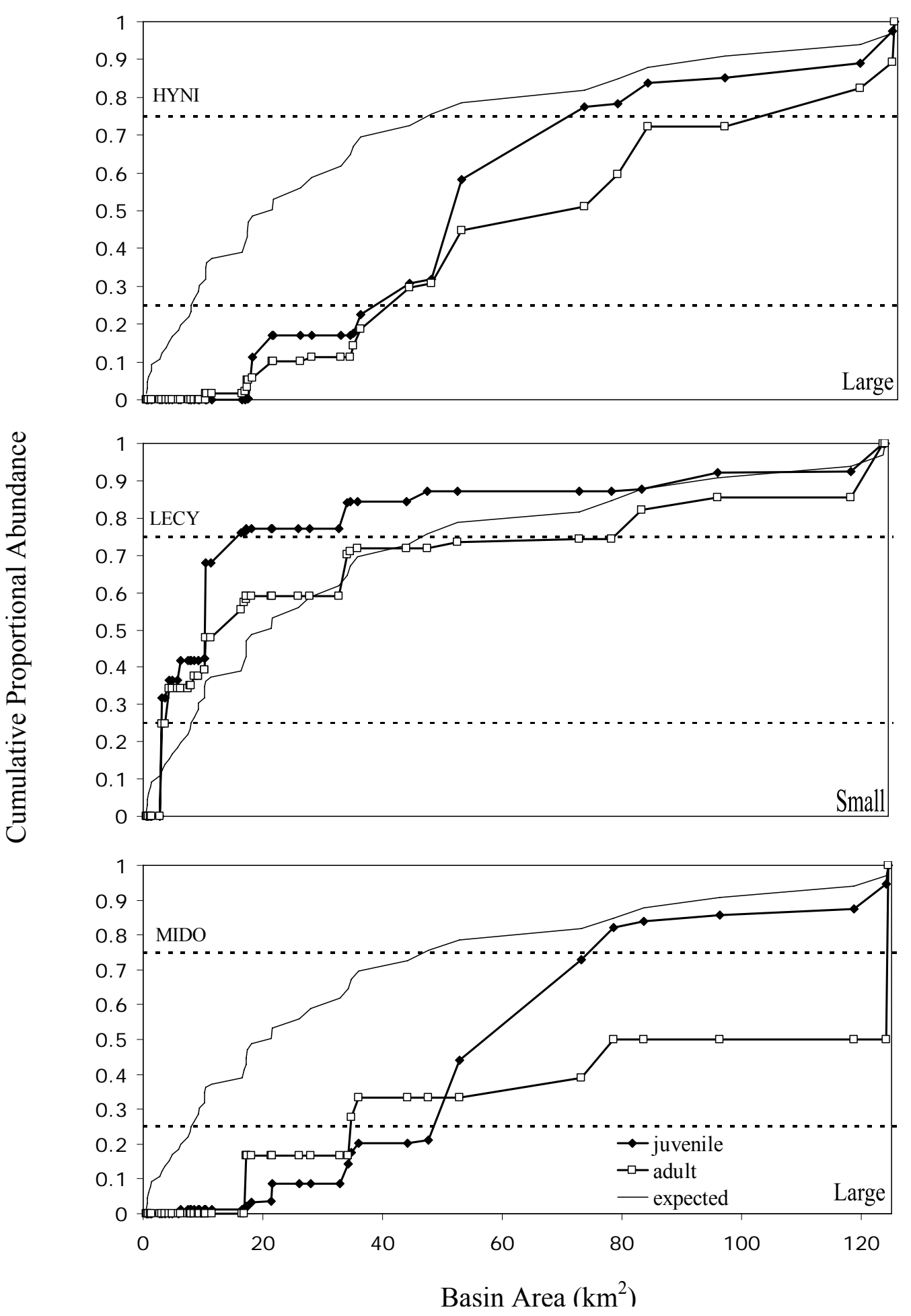

Figure 5.-Continued. Cumulative proportional abundances (\% at each site, of total fish sampled), by species, across increasing basin areas. Species are identified as small-, intermediate-, large-, or ubiquitous-core species. Graphs include adult, juvenile, and expected distributions. Core range is marked with broken line. 

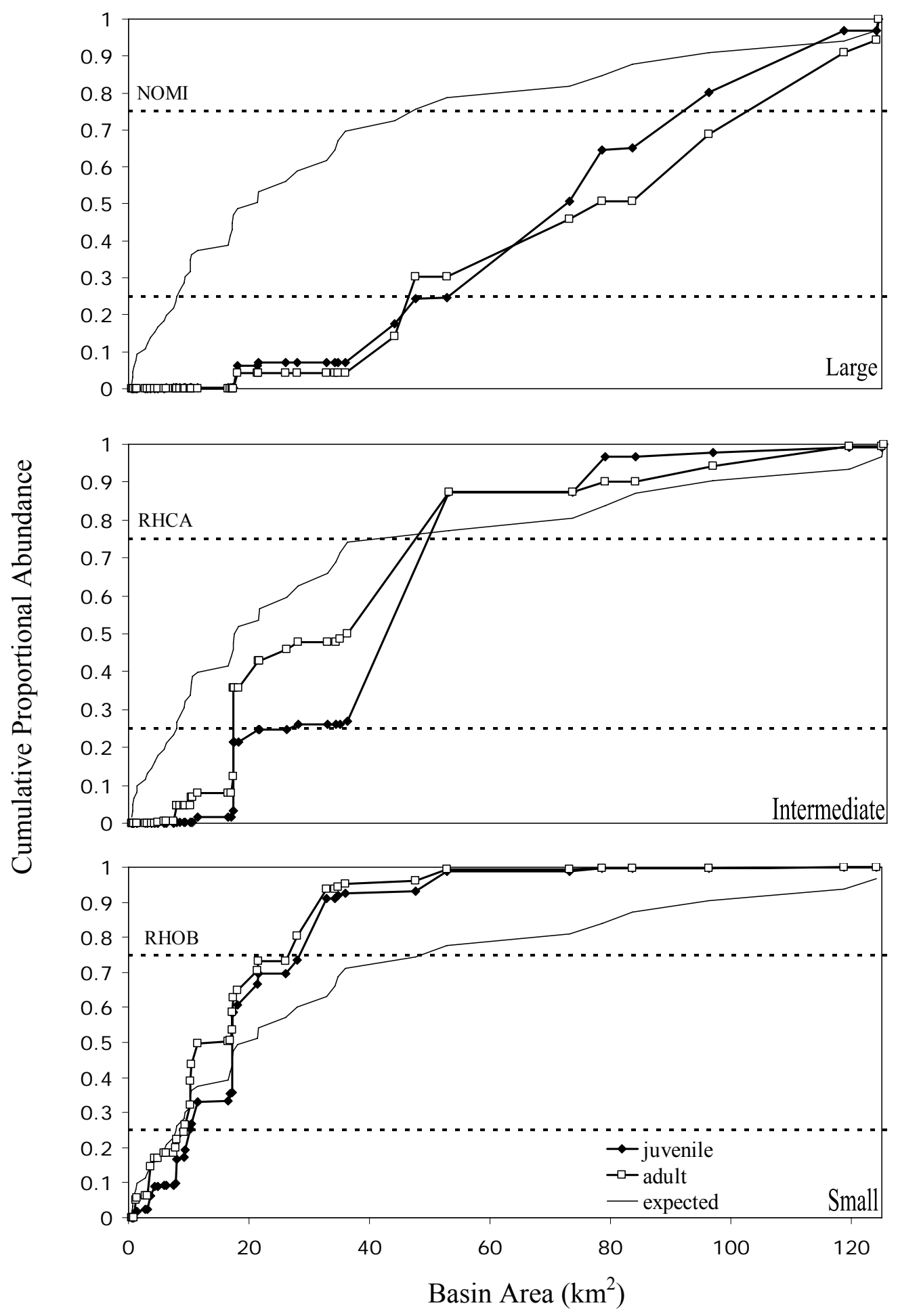

Figure 5.-Continued. Cumulative proportional abundances (\% at each site, of total fish sampled), by species, across increasing basin areas. Species are identified as small-, intermediate-, large-, or ubiquitous-core species. Graphs include adult, juvenile, and expected distributions. Core range is marked with broken line. 


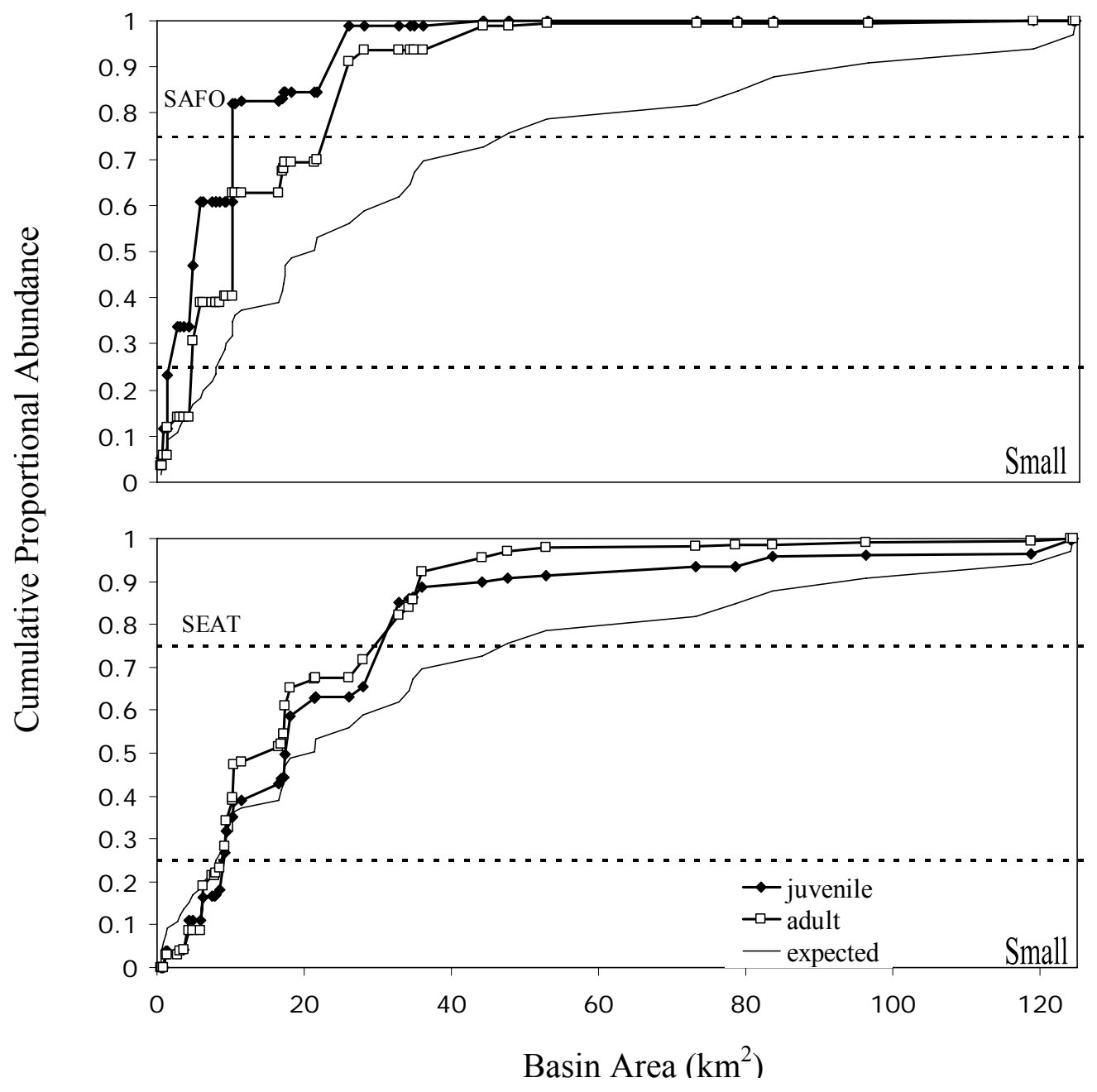

Figure 5.-Continued. Cumulative proportional abundances (\% at each site, of total fish sampled), by species, across increasing basin areas. Species are identified as small-, intermediate-, large-, or ubiquitous-core species. Graphs include adult, juvenile, and expected distributions. Core range is marked with broken line. 

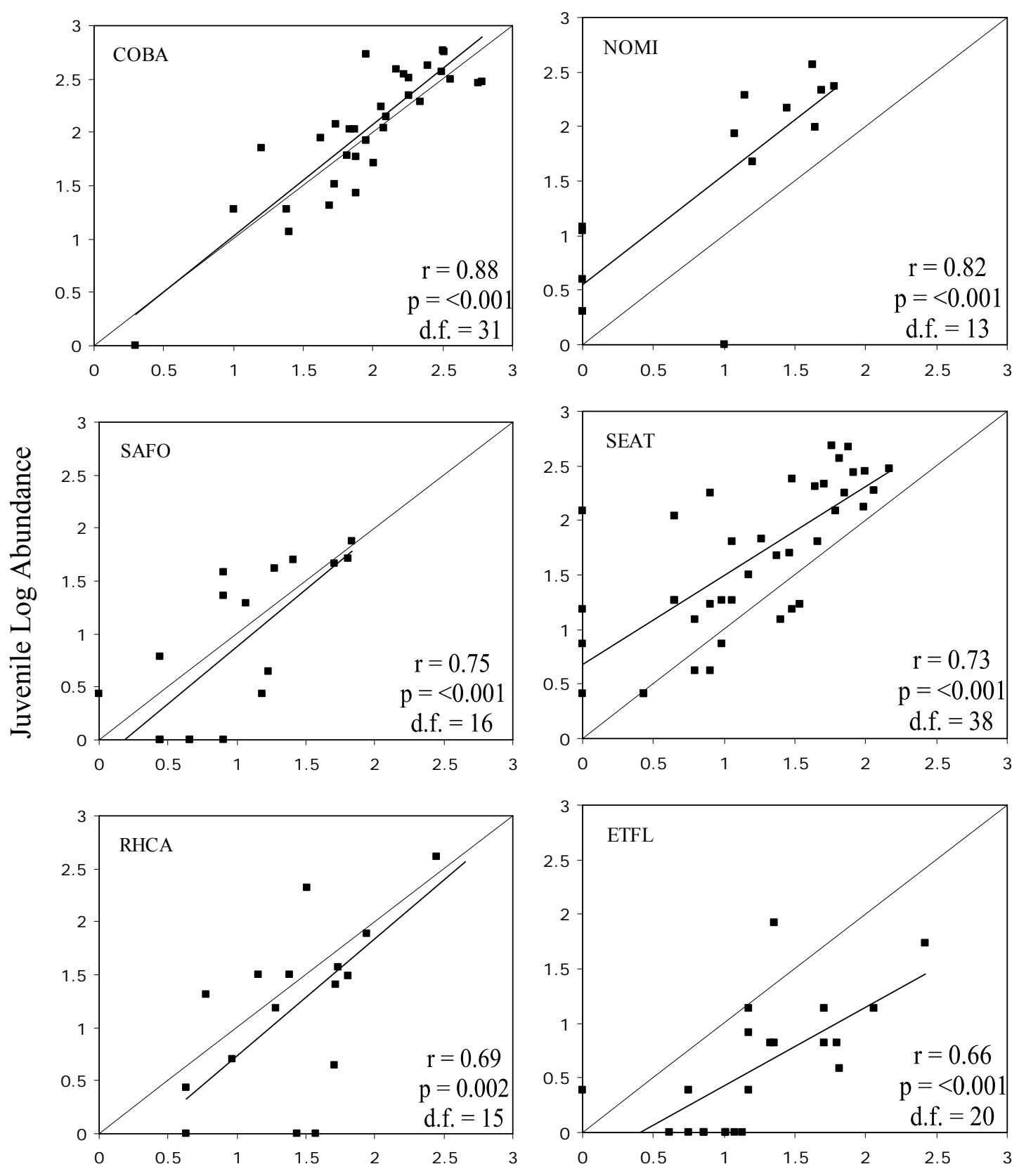

Adult Log Abundance

Figure 6.- Juvenile log abundance plotted against adult log abundance at site, for sites with fish present. Plots include 1:1 line and line of best fit. Species arranged by correlation values, greatest significant to least significant value, and not-significantly correlated. 

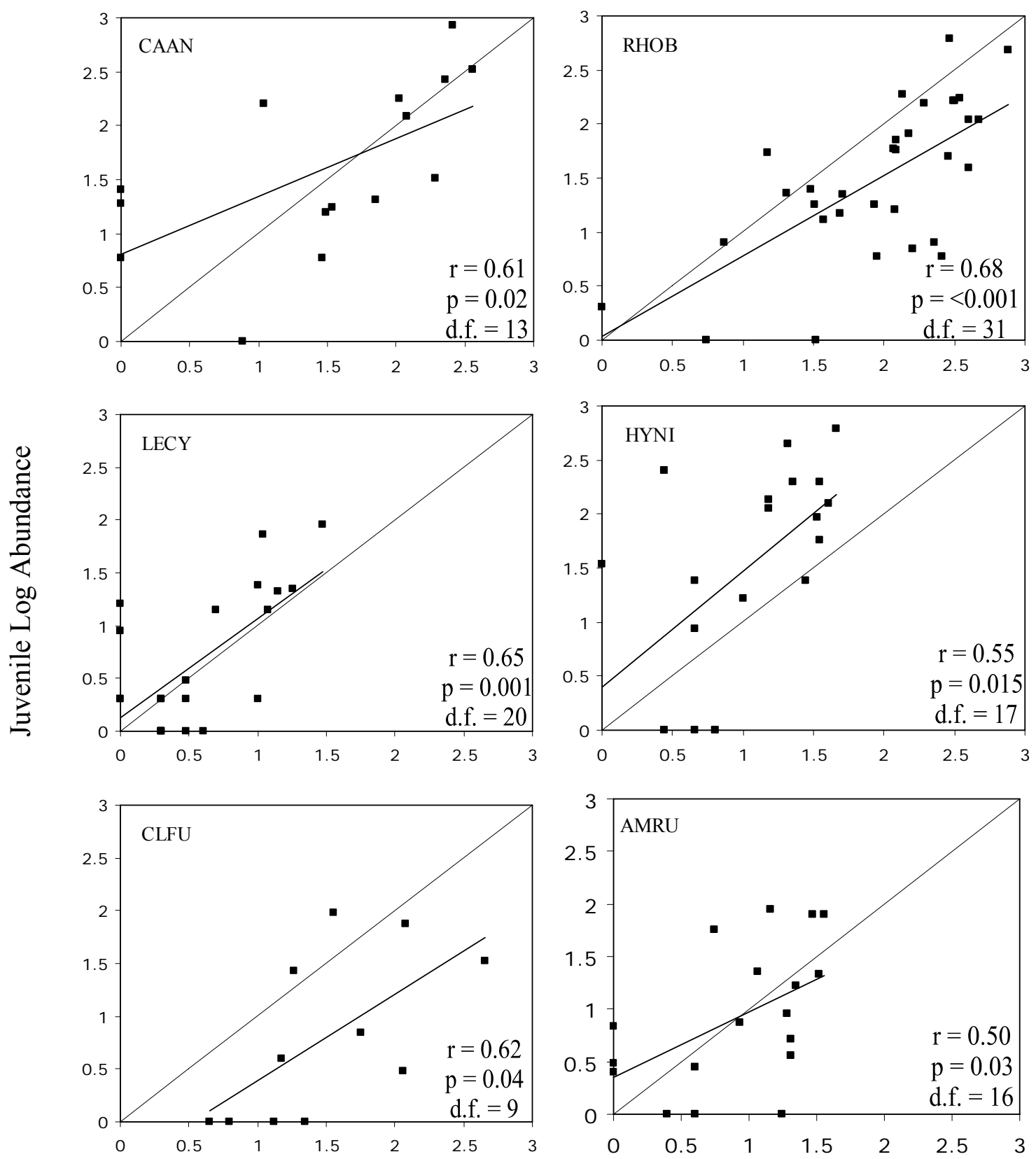

Adult Log Abundance

Figure 6.-Continued. Juvenile log abundance plotted against adult log abundance at site, for sites with fish present. Plots include 1:1 line and line of best fit. Species arranged by correlation values, greatest significant to least significant value, and notsignificantly correlated. 

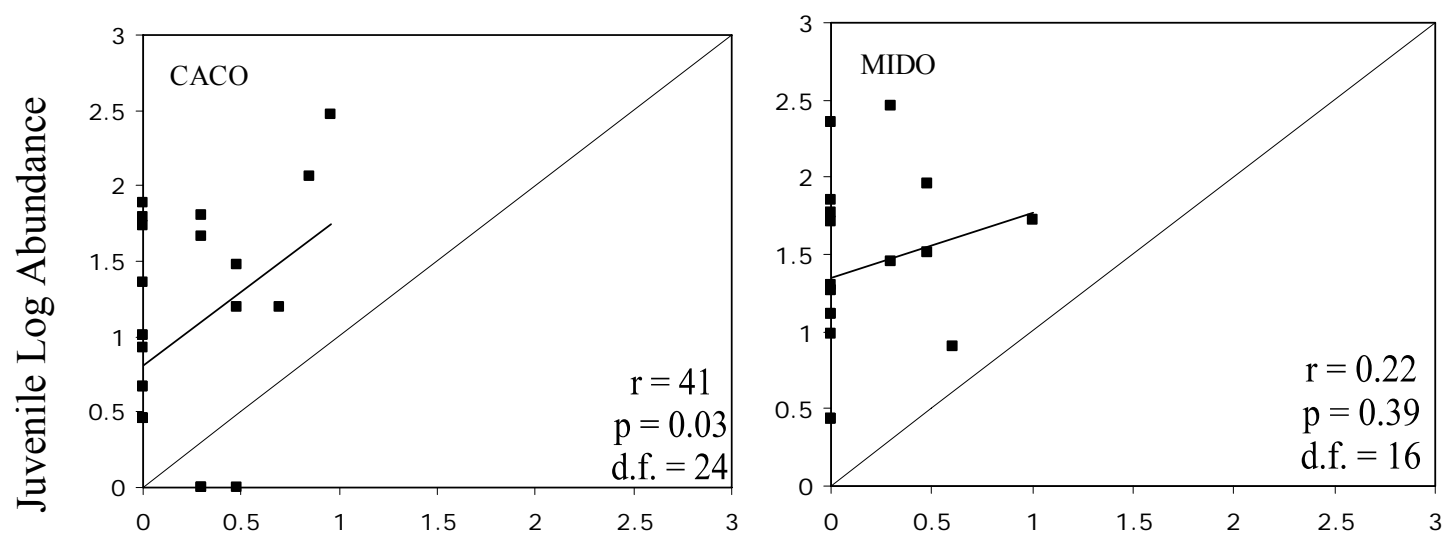

Adult Log Abundance

Figure 6.-Continued. Juvenile log abundance plotted against adult log abundance at site, for sites with fish present. Plots include 1:1 line and line of best fit. Species arranged by correlation values, greatest significant to least significant value, and notsignificantly correlated. 


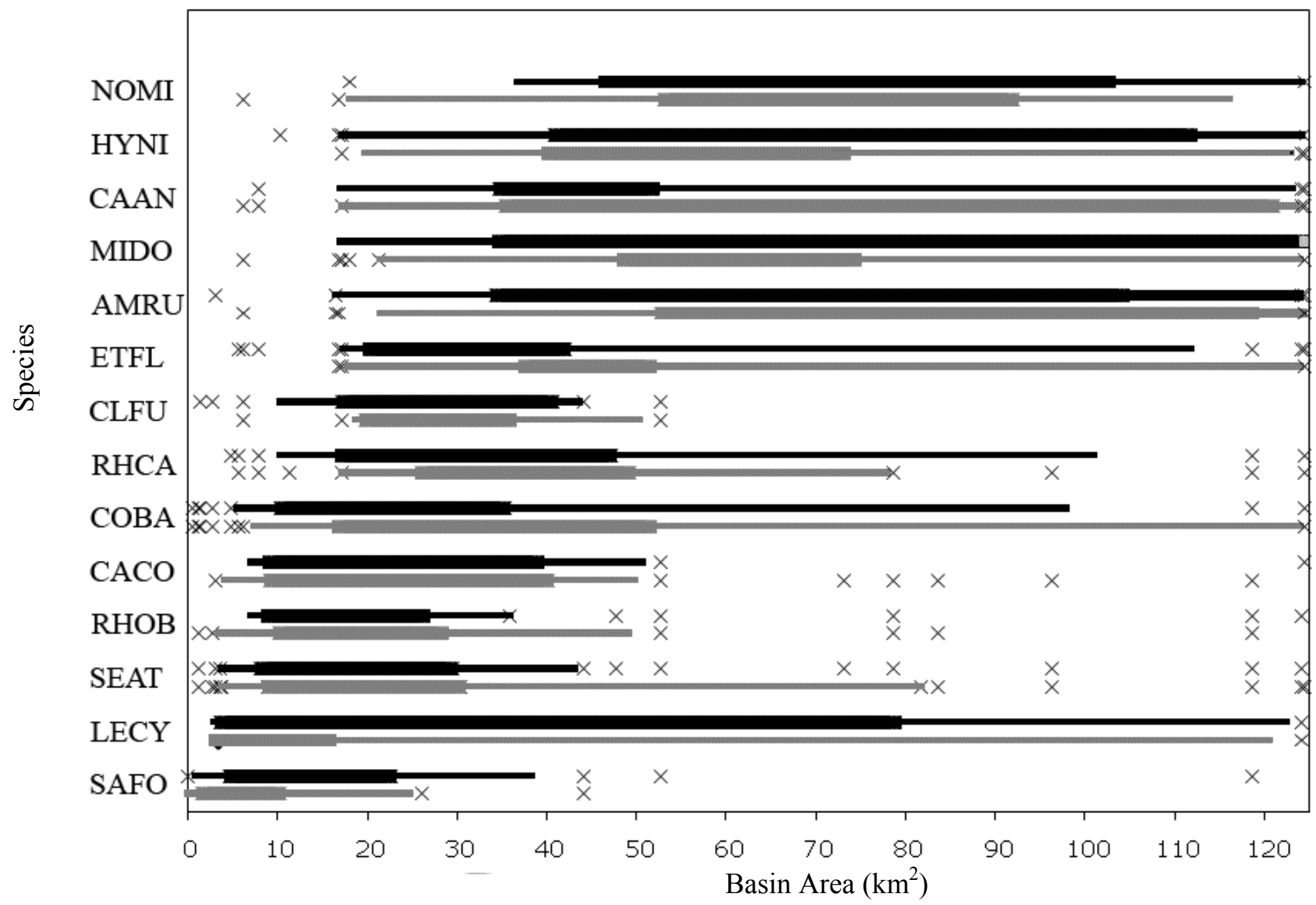

Figure 7.-Core and periphery distributions across basin area size in the watershed. Species are grouped with juvenile distribution in grey and the adult distribution in black. The core area $\left(25^{\text {th }}-75^{\text {th }}\right.$ cumulative proportional abundance) is the thickest part of the line, the periphery (5-25\% and $75-95 \%$ cumulative proportional abundance) is the thin extension, and the " $\mathrm{X}$ " denotes the presence of fish, but outliers in terms of cumulative abundance across the watershed (0-5\% and $95-100 \%)$. 


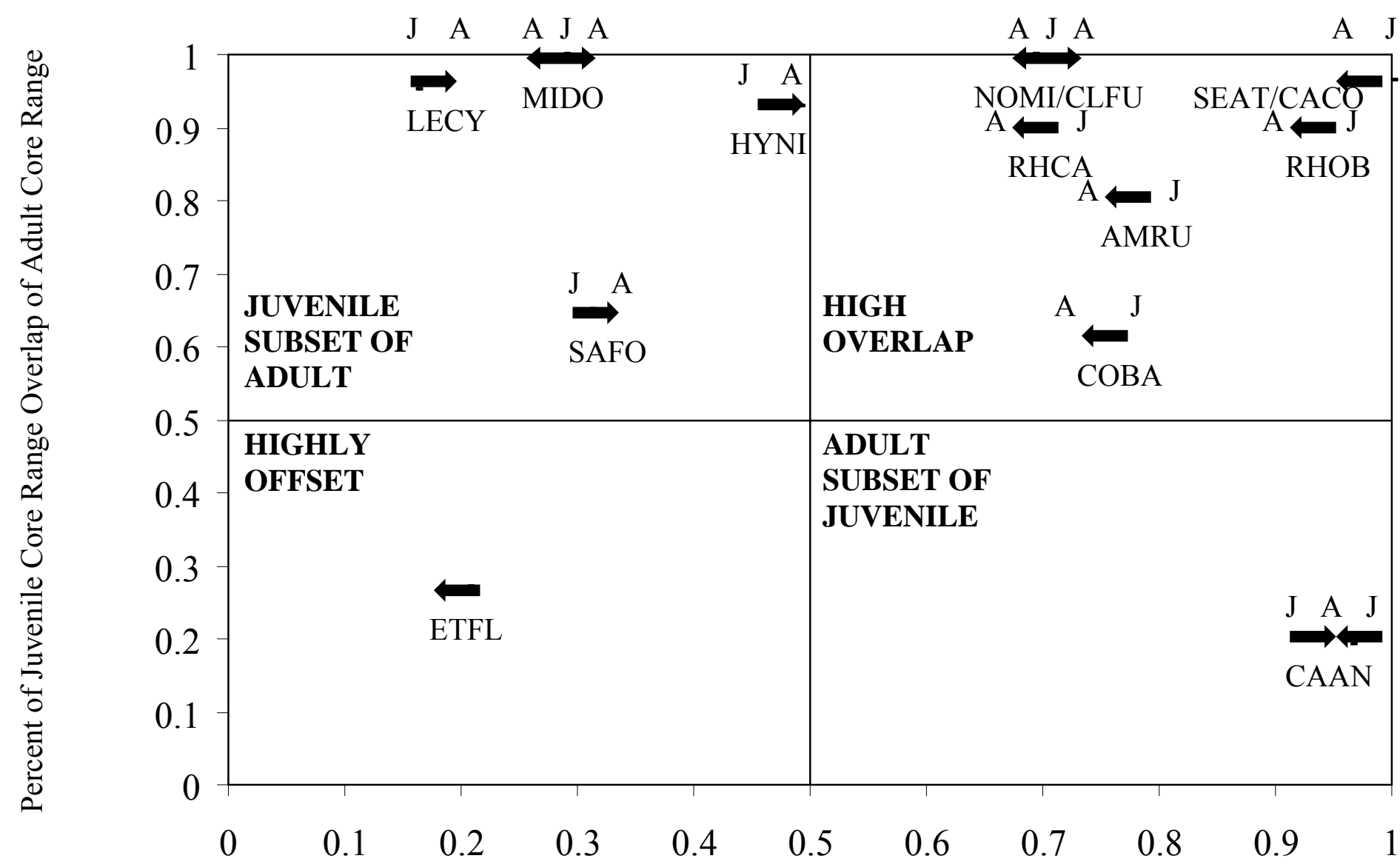

Figure 8.-Classification of species based on percent core overlap to percent uniquely juvenile or adult core range. The arrows represent the direction from the juvenile to adult core, with arrows pointing left indicating upstream direction, and arrows pointing right indicating downstream direction. (A) and ( $\mathrm{J}$ ) correspond with adult and juvenile positions across the drainage area, respectively. 


\section{Appendices}

Appendix 1.1.- Coordinates and characteristics of sites 3-pass sampled in chapter 1. Basin area and approximate coordinates derived from ArcMap. Mean stream width, conductivity, and gradient measured on-site.

\begin{tabular}{|c|c|c|c|c|c|c|}
\hline 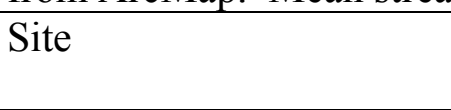 & UTM E & UTM N & Basin Area $\left(\mathrm{km}^{2}\right)$ & MSW (m) & $\begin{array}{l}\text { Conductivity } \\
(\mu \mathrm{s} / \mathrm{cm})\end{array}$ & Gradient (\%) \\
\hline 107 & 0627134 & 4319332 & 7.3 & 4.1 & 147 & 4 \\
\hline 123 & 0630243 & 4317828 & 3.7 & 2.3 & 192 & 6.5 \\
\hline 12 Mile & 0630242 & 4311829 & 4.2 & 5 & 23 & 4 \\
\hline 177 & 0620833 & 4313688 & 2.3 & 4.1 & 87 & 0.3 \\
\hline 190 & 0621187 & 4312767 & 4.7 & 3.8 & 60 & 8 \\
\hline 200 & 0620273 & 4312763 & 0.6 & 2.4 & 71 & 4.7 \\
\hline 323 & 0625148 & 4302618 & 2.5 & 3 & 65 & 8 \\
\hline 379 & 0626322 & 4295319 & 4.5 & 3.5 & 33 & 10.7 \\
\hline 405 & 062335 & 4291603 & 2.1 & 2.6 & 163 & 8 \\
\hline 432 & 0617987 & 4288946 & 2.1 & 2.1 & 79 & 2 \\
\hline Buck Run & 0592252 & 4266111 & 2.8 & 2.9 & 22 & 6.7 \\
\hline Elkwater & 0583901 & 4273843 & 34.8 & 6 & 126 & 1 \\
\hline Leadmine & 0623325 & 4340648 & 15.8 & 9 & 61 & 2.8 \\
\hline Left Fork Files & 0600830 & 4297439 & 17.2 & 4 & 76 & 2.1 \\
\hline Little Oats & 0590959 & 4256114 & 0.5 & 2.4 & 22 & 10.1 \\
\hline Little Odey & 0594579 & 4258736 & 73.9 & 2.6 & 49 & 2.6 \\
\hline Little Odey 10 & 0593703 & 4259582 & 73.9 & 3 & 49 & 4.0 \\
\hline Lower Middle Fork & 0583052 & 4297004 & 78.6 & 12 & 114 & 1.0 \\
\hline Lower UNT Second Fork & 0594643 & 4259118 & 0.1 & 1.8 & 22 & 5.9 \\
\hline Mill Run & 0581854 & 4281103 & 26.1 & 6 & 39 & 0.3 \\
\hline Muddy & 0617038 & 4375591 & 26.6 & 10 & 95 & 2.8 \\
\hline Oats Run & 0591083 & 4256874 & 1.4 & 3.3 & 22 & 7 \\
\hline Odey Run 8 & 0593703 & 4259582 & -- & -- & -- & -- \\
\hline Powerhouse Run & 0590448 & 4257350 & 2.3 & 3.8 & 22 & 2.9 \\
\hline Second Fork 3 & 0593098 & 4262363 & 11.5 & 5.5 & 22 & 2.7 \\
\hline Second Fork 1 & 0594670 & 4271189 & 15.0 & 7.5 & 22 & 1.5 \\
\hline
\end{tabular}


Appendix 1.1. continued

\begin{tabular}{|c|c|c|c|c|c|c|}
\hline Site & UTM N & UTM E & Basin Area $\left(\mathrm{km}^{2}\right)$ & MSW (m) & $\begin{array}{l}\text { Conductivity } \\
(\mu \mathrm{s} / \mathrm{cm})\end{array}$ & Gradient (\%) \\
\hline Second Fork 2 & 0595033 & 4270101 & 12.0 & 6.5 & 22 & 1.5 \\
\hline Second Fork 4 & 0593461 & 4261396 & 10.0 & 5.7 & 22 & 2.7 \\
\hline Second Fork 5 & 0592856 & 4261033 & 8.0 & 5.0 & 22 & 4.5 \\
\hline Second Fork 7 & 0592856 & 4266836 & 5.3 & 5.3 & 22 & 4.5 \\
\hline Second Fork 11 & 0593340 & 4264005 & 4.3 & 5.7 & 22 & 5.3 \\
\hline Shaft Run & 0594361 & 4267952 & 1.7 & 2.4 & 22 & 5.1 \\
\hline Shaft Run 6 & 0596617 & 4272485 & 1.5 & 3 & 22 & 9.1 \\
\hline Shavers Run & 0594124 & 4288736 & 21.4 & 4 & 64 & 1.0 \\
\hline Trout Run & 0570104 & 428537 & 5.8 & 3 & 115 & 1.8 \\
\hline Tygart 219 & 0583211 & 4264185 & 124.4 & 15 & 103 & 2.0 \\
\hline Tygart Valley Head & 0583901 & 4267497 & 52.8 & 11 & 106 & 1.1 \\
\hline UNT of $1^{\text {st }}$ Fork & 0596494 & 4265694 & 2.64 & 3.7 & -- & 5.0 \\
\hline UNT 1 below $1^{\text {st }}$ Fork & 0594826 & 4270550 & 1.53 & 2.2 & -- & 14.1 \\
\hline UNT 2 Below $2^{\text {nd }}$ Fork & 0593777 & 4259703 & 1.1 & 3.1 & 22 & 10.4 \\
\hline UNT 3 below Buck Run & 0593177 & 4266820 & 0.62 & 2.5 & -- & 13.5 \\
\hline UNT 3 below Ryan's Bend & 0591568 & 4262022 & 0.13 & 0.9 & -- & 7.2 \\
\hline UNT 4 of Black Run & 0589229 & 4255708 & 0.08 & 1.3 & -- & 11.1 \\
\hline UNT 5 Below $2^{\text {nd }}$ Fork & 0593589 & 4259496 & 0.2 & 1.6 & 22 & 18.2 \\
\hline UNT 6 Below $2^{\text {nd }}$ Fork & 0593051 & 4257268 & 0.4 & 3.3 & 22 & 9.1 \\
\hline Upper Middle Fork & 0578831 & 4308005 & 10.3 & 5 & 53 & 0.2 \\
\hline UNT of Beaver & 0591617 & 4263950 & -- & -- & -- & -- \\
\hline Upper UNT of $2^{\text {nd }}$ Fork & 0592887 & 4260546 & 0.5 & 1.5 & 22 & 8.5 \\
\hline Watertank & 0596124 & 4269417 & 2.2 & 4.2 & 22 & 7.4 \\
\hline
\end{tabular}


Appendix 1.2.-Capture histories of each fish species and size class sampled and analyzed in chapter 1 . P1, P2, and P3 are passes 1, 2, and 3, respectively of the stream segment.

\begin{tabular}{|c|c|c|c|c|c|}
\hline Site & Species & Size Class & P 1 & P 2 & P 3 \\
\hline 107 & SAFO & Adult & 2 & 0 & 0 \\
\hline \multirow{3}{*}{123} & RHOB & Adult & 333 & 47 & 29 \\
\hline & & Juvenile & 30 & 6 & 1 \\
\hline & SEAT & Juvenile & 1 & 0 & 0 \\
\hline \multirow[t]{8}{*}{177} & CACO & Juvenile & 3 & 0 & 0 \\
\hline & CLFU & Adult & 17 & 3 & 0 \\
\hline & HYNI & Adult & 5 & 1 & 0 \\
\hline & RHOB & Adult & 14 & 6 & 0 \\
\hline & SAFO & Adult & 71 & 13 & 2 \\
\hline & & Juvenile & 75 & 24 & 9 \\
\hline & SEAT & Adult & 10 & 3 & 2 \\
\hline & & Juvenile & 1 & 0 & 0 \\
\hline \multirow[t]{3}{*}{190} & RHCA & Adult & 8 & 5 & 1 \\
\hline & SAFO & Adult & 24 & 1 & 1 \\
\hline & & Juvenile & 54 & 12 & 12 \\
\hline 323 & SEAT & Adult & 2 & 0 & 0 \\
\hline \multirow[t]{2}{*}{405} & RHCA & Adult & 2 & 0 & 1 \\
\hline & RHOB & Adult & 19 & 3 & 1 \\
\hline \multirow[t]{5}{*}{12 Mile } & COBA & Juvenile & 69 & 13 & 21 \\
\hline & SAFO & Adult & 1 & 0 & 0 \\
\hline & & Juvenile & 15 & 10 & 1 \\
\hline & SEAT & Adult & 5 & 1 & 0 \\
\hline & & Juvenile & 1 & 0 & 0 \\
\hline \multirow[t]{2}{*}{ Buck Run } & SAFO & Adult & 27 & 11 & 0 \\
\hline & & Juvenile & 7 & 3 & 0 \\
\hline \multirow[t]{13}{*}{ Elkwater } & AMRU & Juvenile & 1 & 0 & 0 \\
\hline & CAAN & Adult & 1 & 0 & 0 \\
\hline & CLFU & Adult & 34 & 8 & 4 \\
\hline & & Juvenile & 45 & 23 & 7 \\
\hline & COBA & Adult & 106 & 48 & 24 \\
\hline & & Juvenile & 139 & 80 & 34 \\
\hline & HYNI & Juvenile & 4 & 4 & 0 \\
\hline & MIDO & Juvenile & 9 & 2 & 0 \\
\hline & RHCA & Juvenile & 5 & 1 & 1 \\
\hline & RHOB & Adult & 9 & 1 & 0 \\
\hline & & Juvenile & 3 & 1 & 0 \\
\hline & SEAT & Adult & 14 & 4 & 2 \\
\hline & & Juvenile & 70 & 16 & 10 \\
\hline \multirow[t]{3}{*}{ Leadmine } & CACO & Juvenile & 2 & 0 & 0 \\
\hline & COBA & Adult & 163 & 67 & 36 \\
\hline & & Juvenile & 33 & 20 & 6 \\
\hline
\end{tabular}


Appendix 1.2. continued

\begin{tabular}{|c|c|c|c|c|c|}
\hline Site & Species & Size Class & P 1 & P 2 & P 3 \\
\hline \multirow[t]{5}{*}{ Leadmine } & RHCA & Adult & 2 & 0 & 0 \\
\hline & RHOB & Adult & 1 & 0 & 0 \\
\hline & & Juvenile & 1 & 0 & 0 \\
\hline & SAFO & Adult & 4 & 1 & 2 \\
\hline & & Juvenile & 19 & 16 & 3 \\
\hline \multirow[t]{16}{*}{ Left Fork Files } & AMRU & Adult & 84 & 38 & 27 \\
\hline & & Juvenile & 106 & 88 & 67 \\
\hline & CAAN & Adult & 42 & 8 & 3 \\
\hline & & Juvenile & 12 & 2 & 3 \\
\hline & CLFU & Adult & 32 & 6 & 4 \\
\hline & & Juvenile & 6 & 3 & 0 \\
\hline & COBA & Adult & 218 & 83 & 30 \\
\hline & & Juvenile & 128 & 60 & 24 \\
\hline & ETFL & Adult & 8 & 5 & 1 \\
\hline & HYNI & Juvenile & 3 & 0 & 0 \\
\hline & MIDO & Juvenile & 4 & 2 & 1 \\
\hline & RHCA & Adult & 32 & 8 & 4 \\
\hline & & Juvenile & 20 & 7 & 1 \\
\hline & SAFO & Juvenile & 3 & 1 & 0 \\
\hline & SEAT & Adult & 17 & 3 & 1 \\
\hline & & Juvenile & 9 & 6 & 1 \\
\hline \multirow[t]{2}{*}{ Little Oats Run } & SAFO & Adult & 15 & 4 & 1 \\
\hline & & Juvenile & 6 & 2 & 3 \\
\hline \multirow[t]{2}{*}{ Little Odey Run } & SAFO & Adult & 27 & 10 & 1 \\
\hline & & Juvenile & 24 & 15 & 4 \\
\hline \multirow[t]{2}{*}{ Little Odey Run 10} & SAFO & Adult & 14 & 6 & 2 \\
\hline & & Juvenile & 25 & 17 & 7 \\
\hline \multirow[t]{11}{*}{ Lower Middle Fork } & AMRU & Adult & 7 & 2 & 0 \\
\hline & & Juvenile & 2 & 0 & 0 \\
\hline & COBA & Adult & 11 & 4 & 0 \\
\hline & & Juvenile & 8 & 8 & 7 \\
\hline & ETFL & Adult & 1 & 0 & 0 \\
\hline & & Juvenile & 3 & 3 & 1 \\
\hline & HYNI & Adult & 10 & 2 & 0 \\
\hline & MIDO & Juvenile & 23 & 7 & 3 \\
\hline & RHCA & Adult & 5 & 0 & 0 \\
\hline & & Juvenile & 9 & 0 & 0 \\
\hline & SEAT & Juvenile & 2 & 0 & 0 \\
\hline \multirow[t]{2}{*}{ Lower UNT $2^{\text {nd }}$ Fork } & SAFO & Adult & 26 & 4 & 1 \\
\hline & & Juvenile & 19 & 6 & 2 \\
\hline \multirow[t]{2}{*}{ Mill Run } & COBA & Adult & 22 & 8 & 4 \\
\hline & RHCA & Adult & 5 & 1 & 3 \\
\hline
\end{tabular}


Appendix 1.2. continued

\begin{tabular}{|c|c|c|c|c|c|}
\hline Site & Species & Size Class & P 1 & P 2 & P 3 \\
\hline \multirow[t]{2}{*}{ Mill Run } & SAFO & Adult & 5 & 2 & 0 \\
\hline & & Juvenile & 3 & 2 & 3 \\
\hline \multirow[t]{9}{*}{ Muddy } & CACO & Juvenile & 1 & 0 & 0 \\
\hline & COBA & Adult & 96 & 55 & 45 \\
\hline & & Juvenile & 49 & 24 & 29 \\
\hline & RHCA & Adult & 8 & 2 & 1 \\
\hline & & Juvenile & 10 & 7 & 0 \\
\hline & RHOB & Adult & 36 & 0 & 0 \\
\hline & & Juvenile & 18 & 0 & 0 \\
\hline & SAFO & Adult & 5 & 2 & 0 \\
\hline & & Juvenile & 1 & 0 & 0 \\
\hline \multirow[t]{2}{*}{ Oats Run } & SAFO & Adult & 31 & 3 & 0 \\
\hline & & Juvenile & 6 & 2 & 3 \\
\hline Powerhouse Run & SAFO & Juvenile & 8 & 3 & 2 \\
\hline \multirow[t]{14}{*}{$2^{\text {nd }}$ Fork 1} & CAAN & Adult & 23 & 10 & 6 \\
\hline & & Juvenile & 21 & 11 & 1 \\
\hline & CACO & Juvenile & 3 & 1 & 1 \\
\hline & CLFU & Adult & 32 & 12 & 12 \\
\hline & & Juvenile & 7 & 5 & 0 \\
\hline & COBA & Adult & 34 & 18 & 6 \\
\hline & & Juvenile & 6 & 4 & 2 \\
\hline & ETFL & Adult & 11 & 2 & 3 \\
\hline & HYNI & Adult & 5 & 3 & 0 \\
\hline & & Juvenile & 2 & 0 & 0 \\
\hline & RHOB & Adult & 93 & 52 & 16 \\
\hline & & Juvenile & 9 & 6 & 2 \\
\hline & SAFO & Adult & 7 & 2 & 1 \\
\hline & & Juvenile & 12 & 1 & 1 \\
\hline \multirow[t]{6}{*}{$2^{\text {nd }}$ Fork 2} & CAAN & Adult & 2 & 2 & 0 \\
\hline & CACO & Juvenile & 2 & 2 & 2 \\
\hline & COBA & Juvenile & 3 & 2 & 2 \\
\hline & SAFO & Adult & 13 & 5 & 1 \\
\hline & & Juvenile & 8 & 6 & 0 \\
\hline & SEAT & All & 1 & 0 & 0 \\
\hline \multirow[t]{8}{*}{$2^{\text {nd }}$ Fork 3} & CACO & Juvenile & 1 & 1 & 1 \\
\hline & CLFU & Adult & 4 & 3 & 2 \\
\hline & COBA & Juvenile & 1 & 1 & 1 \\
\hline & ETFL & Adult & 1 & 0 & 0 \\
\hline & RHCA & Adult & 4 & 3 & 1 \\
\hline & SAFO & Adult & 21 & 5 & 2 \\
\hline & & Juvenile & 4 & 3 & 1 \\
\hline & CACO & Juvenile & 7 & 3 & 1 \\
\hline
\end{tabular}


Appendix 1.2 continued

\begin{tabular}{|c|c|c|c|c|c|}
\hline Site & Species & Size Class & P 1 & P 2 & P 3 \\
\hline \multirow{4}{*}{$2^{\text {nd }}$ Fork 4} & CLFU & Adult & 1 & 0 & 0 \\
\hline & COBA & Juvenile & 4 & 0 & 0 \\
\hline & SAFO & Adult & 9 & 4 & 4 \\
\hline & & Juvenile & 7 & 3 & 1 \\
\hline \multirow[t]{3}{*}{$2^{\text {nd }}$ Fork 5} & CACO & Juvenile & 2 & 1 & 0 \\
\hline & HYNI & Adult & 2 & 0 & 0 \\
\hline & SEAT & Adult & 1 & 0 & 0 \\
\hline \multirow[t]{2}{*}{$2^{\text {nd }}$ Fork 7} & SAFO & Adult & 10 & 6 & 6 \\
\hline & & Juvenile & 5 & 2 & 0 \\
\hline \multirow[t]{2}{*}{$2^{\text {nd }}$ Fork 11} & SAFO & Adult & 12 & 8 & 2 \\
\hline & & Juvenile & 11 & 2 & 1 \\
\hline \multirow[t]{2}{*}{ Shaft Run } & SAFO & Adult & 24 & 6 & 4 \\
\hline & & Juvenile & 29 & 7 & 3 \\
\hline \multirow[t]{2}{*}{ Shaft Run 6} & COBA & Adult & 14 & 7 & 4 \\
\hline & SAFO & Juvenile & 5 & 2 & 1 \\
\hline \multirow[t]{18}{*}{ Shavers Run } & AMRU & Adult & 1 & 1 & 0 \\
\hline & & Juvenile & 8 & 6 & 3 \\
\hline & CAAN & Adult & 94 & 13 & 12 \\
\hline & & Juvenile & 126 & 33 & 22 \\
\hline & CACO & Juvenile & 6 & 1 & 3 \\
\hline & CLFU & Adult & 51 & 12 & 4 \\
\hline & & Juvenile & 46 & 26 & 21 \\
\hline & COBA & Adult & 239 & 98 & 46 \\
\hline & & Juvenile & 214 & 98 & 64 \\
\hline & ETFL & Adult & 32 & 21 & 12 \\
\hline & & Juvenile & 18 & 9 & 7 \\
\hline & HYNI & Juvenile & 44 & 19 & 9 \\
\hline & MIDO & Juvenile & 1 & 1 & 0 \\
\hline & RHCA & Adult & 31 & 11 & 6 \\
\hline & RHOB & Adult & 94 & 40 & 14 \\
\hline & & Juvenile & 90 & 53 & 23 \\
\hline & SEAT & Adult & 3 & 0 & 0 \\
\hline & SAFO & Juvenile & 3 & 0 & 0 \\
\hline Shavers Run & SEAT & Juvenile & 119 & 39 & 33 \\
\hline \multirow[t]{7}{*}{ Trout Run } & COBA & Adult & 39 & 24 & 13 \\
\hline & & Juvenile & 13 & 6 & 6 \\
\hline & ETFL & Adult & 4 & 1 & 0 \\
\hline & RHOB & Juvenile & 3 & 0 & 0 \\
\hline & SAFO & Adult & 21 & 1 & 1 \\
\hline & & Juvenile & 29 & 7 & 2 \\
\hline & SEAT & Adult & 1 & 0 & 0 \\
\hline \multirow[t]{3}{*}{ Tygart 219} & AMRU & Adult & 7 & 1 & 2 \\
\hline & & Juvenile & 13 & 4 & 2 \\
\hline & CAAN & Adult & 17 & 6 & 6 \\
\hline
\end{tabular}


Appendix 1.2 continued

\begin{tabular}{|c|c|c|c|c|c|}
\hline Site & Species & Size Class & P 1 & P 2 & P 3 \\
\hline \multirow{11}{*}{ Tygart 219} & CACO & All & 1 & 0 & 0 \\
\hline & \multirow[t]{2}{*}{ COBA } & Adult & 89 & 23 & 22 \\
\hline & & Juvenile & 359 & 91 & 136 \\
\hline & \multirow[t]{2}{*}{ ETFL } & Adult & 9 & 7 & 3 \\
\hline & & Juvenile & 9 & 6 & 2 \\
\hline & \multirow[t]{2}{*}{ HYNI } & Adult & 19 & 5 & 1 \\
\hline & & Juvenile & 22 & 7 & 6 \\
\hline & MIDO & Juvenile & 30 & 14 & 20 \\
\hline & \multirow[t]{2}{*}{ RHCA } & Adult & 4 & 2 & 1 \\
\hline & & Juvenile & 21 & 15 & 9 \\
\hline & SEAT & Juvenile & 9 & 5 & 1 \\
\hline \multirow[t]{16}{*}{ Tygart Valley Head } & AMRU & Juvenile & 3 & 0 & 0 \\
\hline & \multirow[t]{2}{*}{ CAAN } & Adult & 114 & 40 & 22 \\
\hline & & Juvenile & 26 & 10 & 6 \\
\hline & $\mathrm{CACO}$ & Juvenile & 5 & 0 & 0 \\
\hline & \multirow[t]{2}{*}{ CLFU } & Adult & 13 & 13 & 6 \\
\hline & & Juvenile & 9 & 2 & 1 \\
\hline & \multirow[t]{2}{*}{ COBA } & Adult & 100 & 44 & 22 \\
\hline & & Juvenile & 202 & 62 & 51 \\
\hline & ETFL & Juvenile & 12 & 9 & 2 \\
\hline & \multirow{2}{*}{ HYNI } & Adult & 7 & 0 & 2 \\
\hline & & Juvenile & 64 & 23 & 19 \\
\hline & MIDO & Juvenile & 20 & 6 & 11 \\
\hline & \multirow[t]{2}{*}{ RHCA } & Adult & 9 & 4 & 3 \\
\hline & & Juvenile & 1 & 0 & 0 \\
\hline & \multirow[t]{2}{*}{ SEAT } & Adult & 16 & 4 & 3 \\
\hline & & Juvenile & 5 & 3 & 4 \\
\hline \multirow{2}{*}{ UNT 2 below $2^{\text {nd }}$ Fork } & \multirow{2}{*}{ SAFO } & Adult & 48 & 10 & 1 \\
\hline & & Juvenile & 17 & 5 & 1 \\
\hline UNT 3 below Buck & SAFO & Adult & 13 & 11 & 1 \\
\hline \multirow[t]{2}{*}{ UNT 3 below Ryan's Bend } & \multirow{2}{*}{ SAFO } & Adult & 10 & 0 & 0 \\
\hline & & Juvenile & 1 & 1 & 1 \\
\hline UNT 4 of Black & SAFO & Adult & 3 & 2 & 0 \\
\hline \multirow[t]{2}{*}{ UNT 5 below $2^{\text {nd }}$ Fork } & \multirow[t]{2}{*}{ SAFO } & Adult & 4 & 1 & 0 \\
\hline & & Juvenile & 12 & 3 & 1 \\
\hline \multirow[t]{2}{*}{ UNT 6 below $2^{\text {nd }}$ Fork } & \multirow[t]{2}{*}{ SAFO } & Adult & 22 & 1 & 0 \\
\hline & & Juvenile & 4 & 1 & 2 \\
\hline \multirow[t]{2}{*}{ UNT of Beaver } & \multirow[t]{2}{*}{ SAFO } & Adult & 19 & 3 & 2 \\
\hline & & Juvenile & 48 & 12 & 2 \\
\hline Upper UNT of $2^{\text {nd }}$ Fork & SAFO & Adult & 15 & 2 & 0 \\
\hline \multirow{4}{*}{ Upper Middle Fork } & $\mathrm{CACO}$ & Juvenile & 7 & 1 & 0 \\
\hline & CLFU & Juvenile & 3 & 2 & 0 \\
\hline & \multirow[t]{2}{*}{ COBA } & Adult & 48 & 19 & 15 \\
\hline & & Juvenile & 36 & 21 & 10 \\
\hline
\end{tabular}




\begin{tabular}{llllll} 
Appendix 1.2 Continued & \multicolumn{1}{l}{} \\
\hline Site & Species & Size Class & P 1 & P 2 & P 3 \\
\hline Upper Middle Fork & RHCA & Adult & 14 & 5 & 1 \\
& HYNI & Adult & 2 & 0 & 0 \\
& RHOB & Adult & 60 & 24 & 19 \\
& & Juvenile & 4 & 1 & 0 \\
& SAFO & Adult & 22 & 4 & 0 \\
& & Juvenile & 22 & 9 & 3 \\
& SEAT & Adult & 2 & 1 & 1 \\
Watertank & \multirow{3}{*}{ SAFO } & Juvenile & 2 & 1 & 1 \\
& & Adult & 15 & 5 & 1 \\
& & Juvenile & 2 & 2 & 0 \\
\hline
\end{tabular}


Appendix 2.1.-Capture efficiency models by size class, variables in models are log transformed, conductivity (cond), mean stream width (msw) and arcsine transformed gradient (grad). Constant models and capture efficiencies are included, as are species and size classes which were found to be variable, but a significant model could not be produced, mean capture efficiencies of these are noted with an $(*)$.

\begin{tabular}{|c|c|c|c|c|c|}
\hline Species & Size Class & Model & Model $\mathrm{R}^{2}$ & Model p-value & Capture efficiency \\
\hline \multirow[t]{2}{*}{ AMRU } & Adult & CONSTANT & & & 0.51 \\
\hline & Juvenile & $=-0.76+(-9.23 \mathrm{grad})+(0.46 \mathrm{msw})+(1.10 \mathrm{cond})$ & 0.98 & 0.02 & \\
\hline \multirow[t]{2}{*}{ CAAN } & Adult & CONSTANT & & & 0.66 \\
\hline & Juvenile & CONSTANT & & & 0.64 \\
\hline $\mathrm{CACO}$ & Juvenile & CONSTANT & & & 0.83 \\
\hline \multirow[t]{2}{*}{ CLFU } & Adult & CONSTANT & & & 0.75 \\
\hline & Juvenile & $\mathrm{N} / \mathrm{A}$ & & & $0.63^{*}$ \\
\hline \multirow[t]{2}{*}{ COBA } & Adult & $\mathrm{N} / \mathrm{A}$ & & & $0.55^{*}$ \\
\hline & Juvenile & CONSTANT & & & 0.51 \\
\hline \multirow[t]{2}{*}{ ETFL } & Adult & CONSTANT & & & 0.55 \\
\hline & Juvenile & CONSTANT & & & 0.41 \\
\hline \multirow[t]{2}{*}{ HYNI } & Adult & CONSTANT & & & 0.80 \\
\hline & Juvenile & CONSTANT & & & 0.56 \\
\hline MIDO & Juvenile & CONSTANT & & & 0.73 \\
\hline \multirow[t]{2}{*}{ RHCA } & Adult & CONSTANT & & & 0.66 \\
\hline & Juvenile & $=-0.520+(6.90 \mathrm{grad})$ & 0.78 & 0.04 & \\
\hline \multirow[t]{2}{*}{ RHOB } & Adult & $=-1.17+(0.73$ cond $)+(0.77 \mathrm{msw})$ & 0.87 & 0.0009 & \\
\hline & Juvenile & N/A & & & $0.82 *$ \\
\hline \multirow[t]{2}{*}{ SAFO } & Adult & CONSTANT & & & 0.77 \\
\hline & Juvenile & CONSTANT & & & 0.69 \\
\hline \multirow[t]{2}{*}{ SEAT } & Adult & CONSTANT & & & 0.74 \\
\hline & Juvenile & CONSTANT & & & 0.60 \\
\hline
\end{tabular}


Appendix 2.2. Names, coordinates, and characteristics of sites sampled in chapter 2.

\begin{tabular}{|c|c|c|c|c|c|c|c|c|}
\hline Site Name & Watershed & UTM E & UTM N & $\begin{array}{l}\text { Basin area } \\
\left(\mathrm{km}^{2}\right)\end{array}$ & $\begin{array}{l}\text { Length } \\
(\mathrm{m})\end{array}$ & $\begin{array}{l}\text { Conductivity } \\
(\mu \mathrm{s} / \mathrm{cm})\end{array}$ & $\begin{array}{l}\text { MSW } \\
(\mathrm{m})\end{array}$ & $\begin{array}{l}\text { Gradient } \\
(\%)\end{array}$ \\
\hline 345 & Cheat & 0613365 & 4301094 & 0.75 & 150 & 111 & 2 & 6.7 \\
\hline 97 & Cheat & 0627492 & 4320119 & 0.66 & 150 & 188 & 3 & 20.3 \\
\hline Becky's Creek of Tygart & Tygart & 0587350 & 4280328 & 36.03 & 240 & 109 & 8 & 1.3 \\
\hline Brain's Creek & Tygart & 0598439 & 4369652 & 9.17 & 200 & 269 & 5 & 3 \\
\hline Conley Run & Tygart & 0584039 & 4269566 & 11.39 & 100 & 150 & 2 & 2.7 \\
\hline Elkwater Fork of Tygart & Tygart & 0583901 & 4273843 & 34.8 & 240 & 126 & 6 & 0.1 \\
\hline Glade Run (Blackwater) & Cheat & 0628459 & 4338640 & 4.30 & 150 & 87 & 2 & . \\
\hline Hog Run & Cheat & 0624449 & 4392501 & 10.27 & 150 & 160 & 1 & 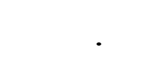 \\
\hline Hunter Fork & Tygart & 0594500 & 4325433 & 16.46 & 160 & 48 & 4 & 0.7 \\
\hline 123 & Cheat & 0630242 & 4317829 & 3.72 & 150 & 201 & 2.3 & 6.7 \\
\hline 196 & Cheat & 0628874 & 4312346 & 2.82 & 150 & 59 & 2.9 & 5.3 \\
\hline 200 & Cheat & 0620273 & 4312763 & 0.60 & 150 & 81 & 2 & 4.3 \\
\hline 201 & Cheat & 0629898 & 4311650 & 0.93 & 150 & 266 & 1.7 & 9.3 \\
\hline 448 & Cheat & 0609622 & 4286570 & 1.41 & 150 & 28 & 1.5 & 2.0 \\
\hline Panther Camp Run & Cheat & 0621275 & 4312673 & 4.83 & 150 & 59 & 3.5 & 3.0 \\
\hline Island Run & Tygart & 0589632 & 4314114 & 3.17 & 150 & 314 & 2 & 7.5 \\
\hline Jones Run & Tygart & 0594801 & 4292894 & 6.28 & 150 & 78 & 2 & 0.2 \\
\hline Laurel Run of Middle Fork & Tygart & 0578895 & 4307688 & 21.60 & 280 & 128 & 12 & 1.3 \\
\hline Leading Creek & Tygart & 0598882 & 4311314 & 124.09 & 300 & 194 & 10 & 0.2 \\
\hline Left Fork Buckhannon & Tygart & 0568310 & 4291947 & 96.34 & 300 & 48 & 12 & 1.5 \\
\hline Left Fork of Files Creek & Tygart & 0600830 & 4297439 & 17.2 & 160 & 76 & 4 & 2.1 \\
\hline Little Laurel Run & Cheat & 0609604 & 4389551 & 17.37 & 240 & 138 & 6 & 2.8 \\
\hline Log Lick & Tygart & 0603386 & 4316061 & 7.90 & 150 & 61 & 2 & 1.7 \\
\hline $\begin{array}{l}\text { Left Fork of Right Fork of } \\
\text { Buckhannon }\end{array}$ & Tygart & 0613488 & 4300968 & 47.70 & 300 & 211 & 10 & $\cdot$ \\
\hline
\end{tabular}




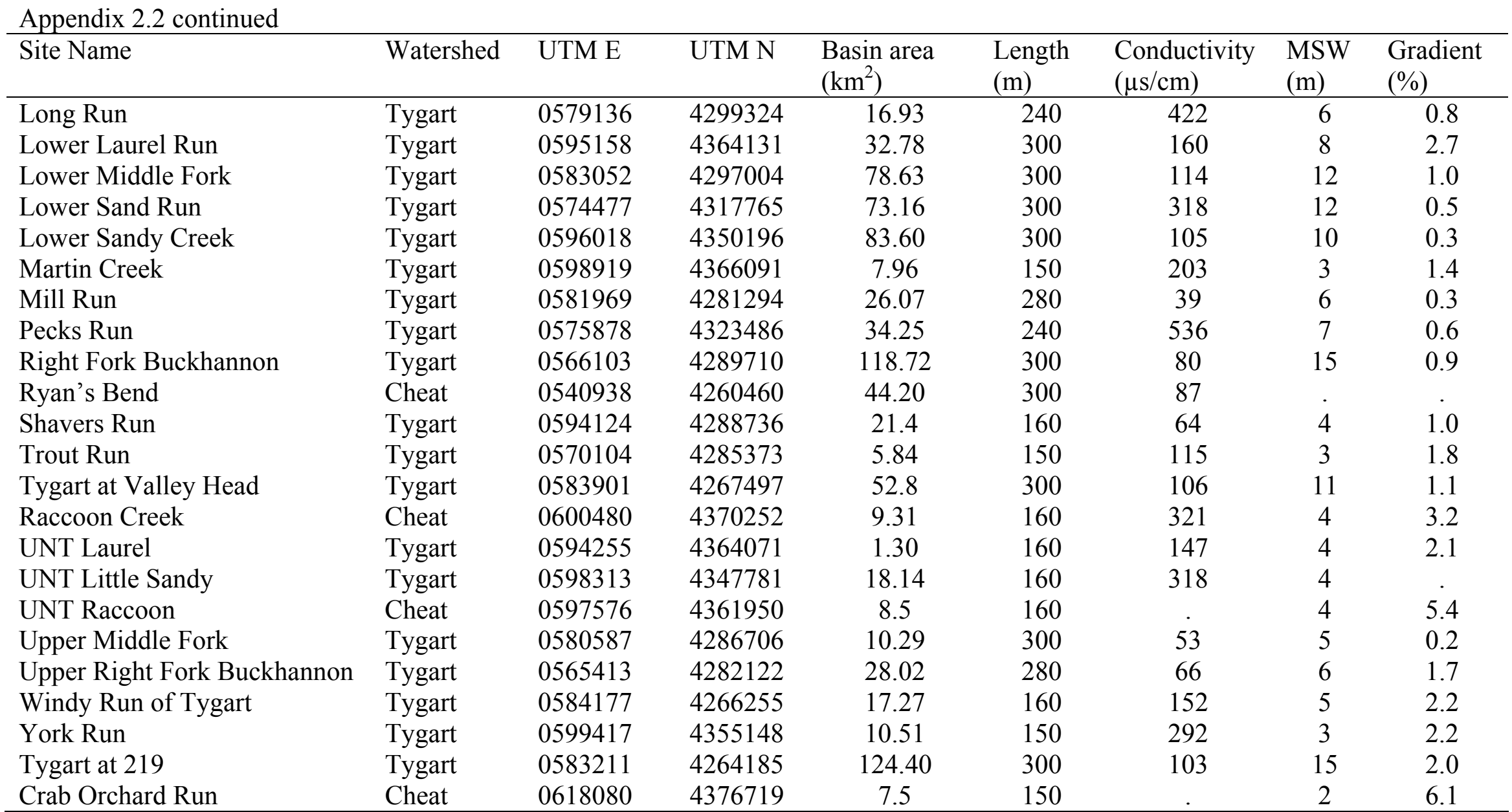


Appendix 2.3.- Sampled fish abundances for each species and size class at each site for chapter 2.

\begin{tabular}{|c|c|c|c|c|c|c|c|c|c|c|c|c|c|c|}
\hline Site & $\begin{array}{c}\text { AMRU } \\
\text { A }\end{array}$ & $\begin{array}{l}\text { AMRU } \\
\mathrm{J}\end{array}$ & $\begin{array}{c}\text { CAAN } \\
\text { A }\end{array}$ & $\begin{array}{l}\text { CAAN } \\
\text { J }\end{array}$ & $\begin{array}{c}\text { CACO } \\
\text { A }\end{array}$ & $\begin{array}{c}\text { CACO } \\
\text { J }\end{array}$ & $\begin{array}{c}\text { CLFU } \\
\text { A }\end{array}$ & $\begin{array}{c}\text { CLFU } \\
\mathrm{J}\end{array}$ & $\begin{array}{c}\text { COBA } \\
\text { A }\end{array}$ & $\begin{array}{c}\text { COBA } \\
\mathrm{J}\end{array}$ & $\begin{array}{c}\text { ETFL } \\
\text { A }\end{array}$ & $\begin{array}{c}\text { ETFL } \\
\text { J }\end{array}$ & $\begin{array}{c}\text { HYNI } \\
\text { A }\end{array}$ & $\begin{array}{c}\text { HYNI } \\
\text { J }\end{array}$ \\
\hline 345 & 0 & 0 & 0 & 0 & 0 & 0 & 0 & 0 & 0 & 0 & 0 & 0 & 0 & 0 \\
\hline 97 & 0 & 0 & 0 & 0 & 0 & 0 & 0 & 0 & 0 & 0 & 0 & 0 & 0 & 0 \\
\hline Becky's Creek & 2 & 1 & 138 & 160 & 0 & 1 & 68 & 74 & 572 & 192 & 40 & 4 & 8 & 44 \\
\hline Brain's Creek & 0 & 0 & 0 & 0 & 6 & 62 & 0 & 0 & 0 & 0 & 0 & 0 & 0 & 0 \\
\hline Conley Run & 0 & 0 & 0 & 0 & 0 & 0 & 0 & 0 & 147 & 255 & 0 & 0 & 0 & 0 \\
\hline Elkwater Fork & 14 & 6 & 20 & 10 & 2 & 8 & 7 & 0 & 165 & 233 & 32 & 9 & 5 & 6 \\
\hline Glade Run & 0 & 0 & 0 & 0 & 0 & 33 & 0 & 0 & 0 & 0 & 0 & 0 & 0 & 0 \\
\hline Hog Run & 0 & 0 & 0 & 0 & 0 & 42 & 0 & 0 & 15 & 46 & 0 & 0 & 0 & 0 \\
\hline Hunter Fork & 5 & 4 & 0 & 0 & 4 & 8 & 0 & 0 & 53 & 77 & 0 & 0 & 0 & 0 \\
\hline 123 & 0 & 0 & 0 & 0 & 0 & 0 & 0 & 0 & 0 & 0 & 0 & 0 & 0 & 0 \\
\hline 196 & 0 & 0 & 0 & 0 & 0 & 0 & 2 & 0 & 24 & 7 & 0 & 0 & 0 & 0 \\
\hline 200 & 0 & 0 & 0 & 0 & 0 & 0 & 0 & 0 & 9 & 12 & 0 & 0 & 0 & 0 \\
\hline 201 & 0 & 0 & 0 & 0 & 0 & 0 & 0 & 0 & 0 & 0 & 0 & 0 & 0 & 0 \\
\hline 448 & 0 & 0 & 0 & 0 & 0 & 0 & 12 & 0 & 23 & 12 & 0 & 0 & 0 & 0 \\
\hline Panther Camp & 0 & 0 & 0 & 0 & 0 & 0 & 0 & 0 & 48 & 13 & 0 & 0 & 0 & 0 \\
\hline Island Run & 0 & 0 & 0 & 0 & 0 & 1 & 0 & 0 & 0 & 0 & 0 & 0 & 0 & 0 \\
\hline Jones Run & 0 & 1 & 0 & 11 & 0 & 29 & 8 & 3 & 88 & 55 & 3 & 0 & 0 & 0 \\
\hline $\begin{array}{l}\text { Laurel Run of } \\
\text { Middle F. }\end{array}$ & 12 & 4 & 0 & 0 & 0 & 0 & 0 & 0 & 68 & 70 & 7 & 0 & 0 & 0 \\
\hline
\end{tabular}




\begin{tabular}{|c|c|c|c|c|c|c|c|c|c|c|c|c|c|c|}
\hline Appendix 2.3 & $\begin{array}{c}\text { AMRU } \\
\text { A }\end{array}$ & $\begin{array}{c}\text { AMRU } \\
\mathrm{J}\end{array}$ & $\begin{array}{c}\text { CAAN } \\
\text { A }\end{array}$ & $\begin{array}{c}\text { CAAN } \\
\text { J }\end{array}$ & $\begin{array}{c}\mathrm{CACO} \\
\mathrm{A}\end{array}$ & $\begin{array}{c}\mathrm{CACO} \\
\mathrm{J}\end{array}$ & $\begin{array}{c}\text { CLFU } \\
\text { A }\end{array}$ & $\begin{array}{c}\text { CLFU } \\
\mathrm{J}\end{array}$ & $\begin{array}{c}\text { COBA } \\
\text { A }\end{array}$ & $\begin{array}{c}\text { COBA } \\
\mathrm{J}\end{array}$ & $\begin{array}{c}\text { ETFL } \\
\text { A }\end{array}$ & $\begin{array}{c}\text { ETFL } \\
\mathrm{J}\end{array}$ & $\begin{array}{c}\text { HYNI } \\
\text { A }\end{array}$ & $\begin{array}{c}\text { HYNI } \\
\mathrm{J}\end{array}$ \\
\hline Leading Creek & 19 & 28 & 155 & 518 & 0 & 0 & 0 & 0 & 0 & 0 & 13 & 4 & 12 & 77 \\
\hline L.F. Buckhannon & 11 & 0 & 0 & 0 & 0 & 1 & 0 & 0 & 64 & 39 & 2 & 0 & 0 & 13 \\
\hline L.F. of Files Creek & 84 & 106 & 42 & 12 & 1 & 0 & 32 & 6 & 218 & 128 & 8 & 0 & 2 & 3 \\
\hline $\begin{array}{l}\text { L.F. of R.F. of } \\
\text { Buckhannon }\end{array}$ & 2 & 0 & 0 & 0 & 0 & 1 & 0 & 0 & 75 & 38 & 6 & 0 & 2 & 9 \\
\hline Little Laurel Run & 0 & 0 & 0 & 0 & 0 & 0 & 0 & 0 & 358 & 208 & 0 & 0 & 0 & 0 \\
\hline Log Lick & 0 & 0 & 18 & 9 & 0 & 0 & 0 & 0 & 247 & 281 & 6 & 0 & 0 & 0 \\
\hline Long Run & 13 & 1 & 0 & 0 & 0 & 5 & 0 & 0 & 120 & 71 & 3 & 1 & 1 & 0 \\
\hline Lower Laurel Run & 0 & 1 & 0 & 0 & 0 & 0 & 0 & 0 & 310 & 245 & 0 & 0 & 0 & 0 \\
\hline Lower Middle F. & 13 & 2 & 0 & 3 & 0 & 1 & 0 & 0 & 73 & 70 & 9 & 5 & 15 & 9 \\
\hline Lower Sand Run & 23 & 28 & 6 & 96 & 0 & 4 & 0 & 0 & 41 & 58 & 4 & 0 & 11 & 175 \\
\hline $\begin{array}{l}\text { Lower Sandy } \\
\text { Creek }\end{array}$ & 9 & 36 & 0 & 0 & 0 & 2 & 0 & 0 & 0 & 0 & 14 & 4 & 22 & 49 \\
\hline Martin Creek & 0 & 0 & 0 & 0 & 0 & 0 & 0 & 0 & 0 & 0 & 0 & 0 & 0 & 0 \\
\hline Mill Run & 0 & 0 & 0 & 0 & 0 & 0 & 0 & 0 & 75 & 17 & 0 & 0 & 0 & 0 \\
\hline Pecks Run & 3 & 19 & 4 & 0 & 0 & 1 & 0 & 0 & 0 & 0 & 0 & 0 & 0 & 0 \\
\hline R.F. Buckhannon & 21 & 10 & 0 & 0 & 0 & 1 & 0 & 0 & 179 & 215 & 9 & 1 & 18 & 36 \\
\hline Ryan's Bend & 0 & 0 & 117 & 19 & 8 & 161 & 261 & 32 & 179 & 147 & 170 & 37 & 19 & 76 \\
\hline
\end{tabular}




\begin{tabular}{|c|c|c|c|c|c|c|c|c|c|c|c|c|c|c|}
\hline Appendix 2.3 & $\begin{array}{c}\text { AMRU } \\
\text { A }\end{array}$ & $\begin{array}{c}\text { AMRU } \\
\mathrm{J}\end{array}$ & $\begin{array}{c}\text { CAAN } \\
\text { A }\end{array}$ & $\begin{array}{c}\text { CAAN } \\
\mathrm{J}\end{array}$ & $\begin{array}{c}\mathrm{CACO} \\
\mathrm{A}\end{array}$ & $\begin{array}{c}\mathrm{CACO} \\
\mathrm{J}\end{array}$ & $\begin{array}{c}\text { CLFU } \\
\mathrm{A}\end{array}$ & $\begin{array}{c}\text { CLFU } \\
\mathrm{J}\end{array}$ & $\begin{array}{c}\mathrm{COBA} \\
\mathrm{A}\end{array}$ & $\begin{array}{c}\mathrm{COBA} \\
\mathrm{J}\end{array}$ & $\begin{array}{c}\text { ETFL } \\
\text { A }\end{array}$ & $\begin{array}{c}\text { ETFL } \\
\mathbf{J}\end{array}$ & $\begin{array}{l}\text { HYNI } \\
\text { A }\end{array}$ & $\begin{array}{l}\text { HYNI } \\
\mathrm{J}\end{array}$ \\
\hline Shavers Run & 0 & 0 & 63 & 108 & 0 & 5 & 20 & 95 & 322 & 375 & 42 & 2 & 8 & 53 \\
\hline Trout Run & 0 & 0 & 0 & 0 & 0 & 0 & 0 & 0 & 52 & 21 & 4 & 0 & 0 & 0 \\
\hline $\begin{array}{l}\text { Tygart Valley } \\
\text { Head }\end{array}$ & 0 & 3 & 218 & 200 & 1 & 25 & 10 & 26 & 391 & 864 & 14 & 58 & 25 & 241 \\
\hline Raccoon Creek & 0 & 0 & 0 & 0 & 0 & 0 & 0 & 0 & 0 & 0 & 0 & 0 & 0 & 0 \\
\hline UNT Laurel & 0 & 0 & 0 & 0 & 0 & 0 & 0 & 0 & 123 & 92 & 0 & 0 & 0 & 0 \\
\hline UNT Little Sandy & 3 & 7 & 0 & 0 & 0 & 2 & 0 & 0 & 1 & 0 & 73 & 9 & 1 & 99 \\
\hline UNT Raccoon & 0 & 0 & 0 & 0 & 0 & 0 & 0 & 0 & 0 & 0 & 0 & 0 & 0 & 0 \\
\hline $\begin{array}{l}\text { Upper Middle } \\
\text { Fork }\end{array}$ & 0 & 0 & 0 & 0 & 0 & 12 & 3 & 0 & 114 & 115 & 0 & 0 & 3 & 0 \\
\hline $\begin{array}{l}\text { Upper R. F. } \\
\text { Buckhannon }\end{array}$ & 0 & 0 & 0 & 15 & 1 & 34 & 0 & 0 & 101 & 33 & 32 & 4 & 2 & 0 \\
\hline $\begin{array}{l}\text { Windy Run of } \\
\text { Tygart }\end{array}$ & 0 & 0 & 71 & 73 & 0 & 0 & 65 & 2 & 320 & 387 & 0 & 1 & 3 & 0 \\
\hline York Run & 0 & 0 & 0 & 0 & 2 & 16 & 0 & 0 & 609 & 198 & 0 & 0 & 0 & 0 \\
\hline Tygart 219 & 7 & 13 & 17 & 3 & 1 & 0 & 0 & 0 & 89 & 359 & 9 & 9 & 19 & 22 \\
\hline $\begin{array}{l}\text { Crab Orchard } \\
\text { Run }\end{array}$ & 0 & 0 & 0 & 0 & 2 & 0 & 0 & 0 & 0 & 0 & 0 & 0 & 0 & 0 \\
\hline
\end{tabular}


Appendix 2.3.--continued

\begin{tabular}{|c|c|c|c|c|c|c|c|c|c|c|c|c|c|c|}
\hline Site & $\begin{array}{c}\text { LECY } \\
\text { A }\end{array}$ & $\begin{array}{c}\text { LECY } \\
\mathrm{J}\end{array}$ & $\begin{array}{c}\text { MIDO } \\
\text { A }\end{array}$ & $\begin{array}{c}\text { MIDO } \\
\text { J }\end{array}$ & $\begin{array}{c}\text { NOMI } \\
\text { A }\end{array}$ & $\begin{array}{c}\text { NOMI } \\
\mathrm{J}\end{array}$ & $\begin{array}{c}\text { RHCA } \\
\text { A }\end{array}$ & $\begin{array}{c}\text { RHCA } \\
\text { J }\end{array}$ & $\begin{array}{c}\text { RHOB } \\
\text { A }\end{array}$ & $\begin{array}{c}\text { RHOB } \\
\mathrm{J}\end{array}$ & $\begin{array}{c}\text { SAFO } \\
\text { A }\end{array}$ & $\begin{array}{c}\text { SAFO } \\
\mathrm{J}\end{array}$ & $\begin{array}{c}\text { SEAT } \\
\text { A }\end{array}$ & $\begin{array}{c}\text { SEAT } \\
\mathrm{J}\end{array}$ \\
\hline 345 & 0 & 0 & 0 & 0 & 0 & 0 & 0 & 0 & 0 & 0 & 0 & 0 & 0 & 0 \\
\hline 97 & 0 & 0 & 0 & 0 & 0 & 0 & 0 & 0 & 0 & 0 & 0 & 0 & 0 & 0 \\
\hline Brain's Creek & 0 & 0 & 0 & 0 & 0 & 0 & 0 & 0 & 55 & 15 & 2 & 0 & 43 & 296 \\
\hline Conley Run & 0 & 0 & 0 & 0 & 0 & 0 & 8 & 16 & 208 & 172 & 0 & 1 & 4 & 10 \\
\hline Elkwater Fork & 1 & 1 & 2 & 18 & 0 & 0 & 5 & 4 & 15 & 24 & 0 & 0 & 14 & 7 \\
\hline Hunter Fork & 9 & 23 & 0 & 0 & 0 & 0 & 0 & 0 & 24 & 12 & 0 & 0 & 29 & 133 \\
\hline 123 & 0 & 0 & 0 & 0 & 0 & 0 & 0 & 0 & 264 & 107 & 0 & 0 & 3 & 2 \\
\hline 196 & 0 & 0 & 0 & 0 & 0 & 0 & 0 & 0 & 21 & 17 & 4 & 22 & 0 & 1 \\
\hline
\end{tabular}




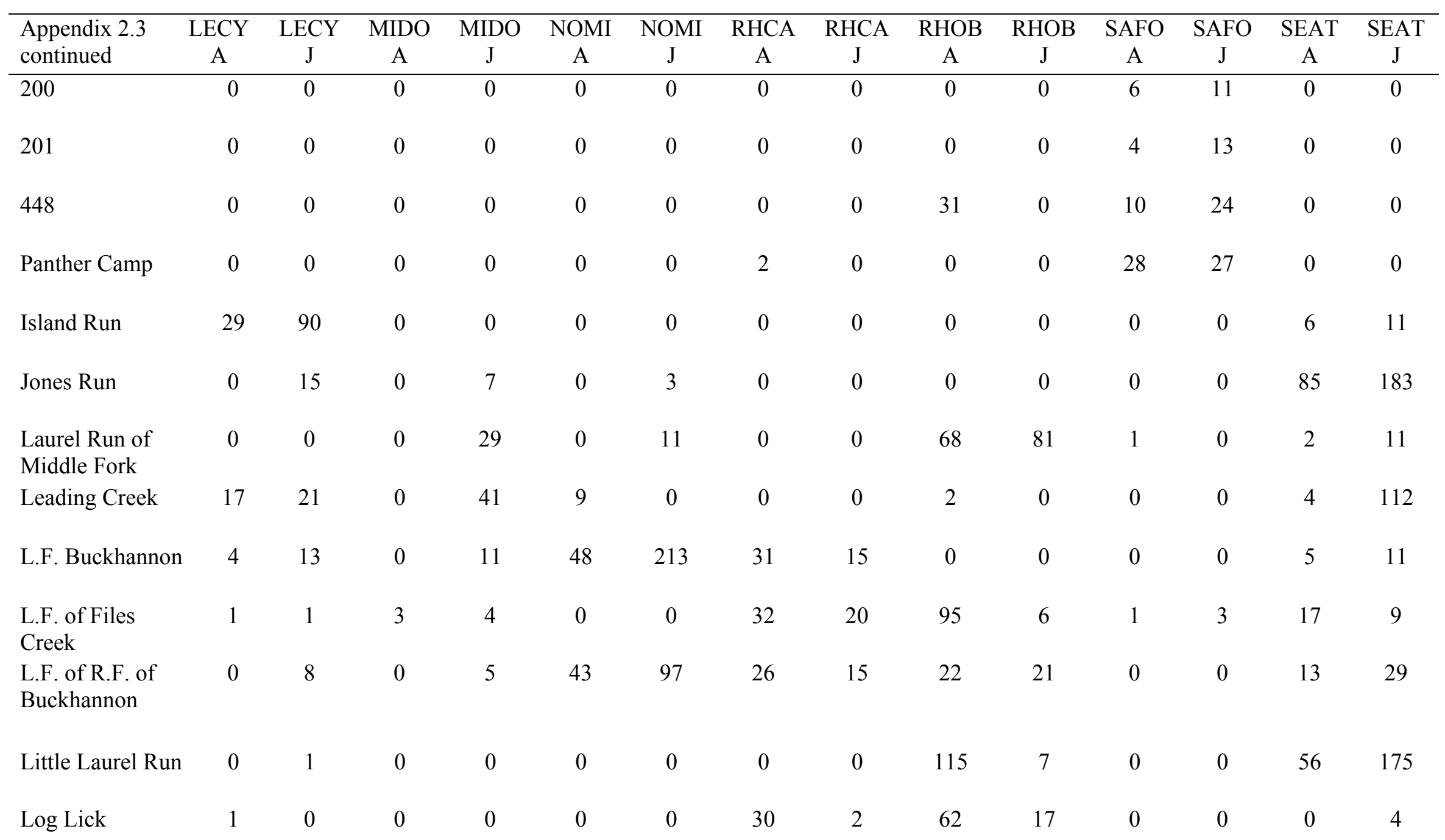




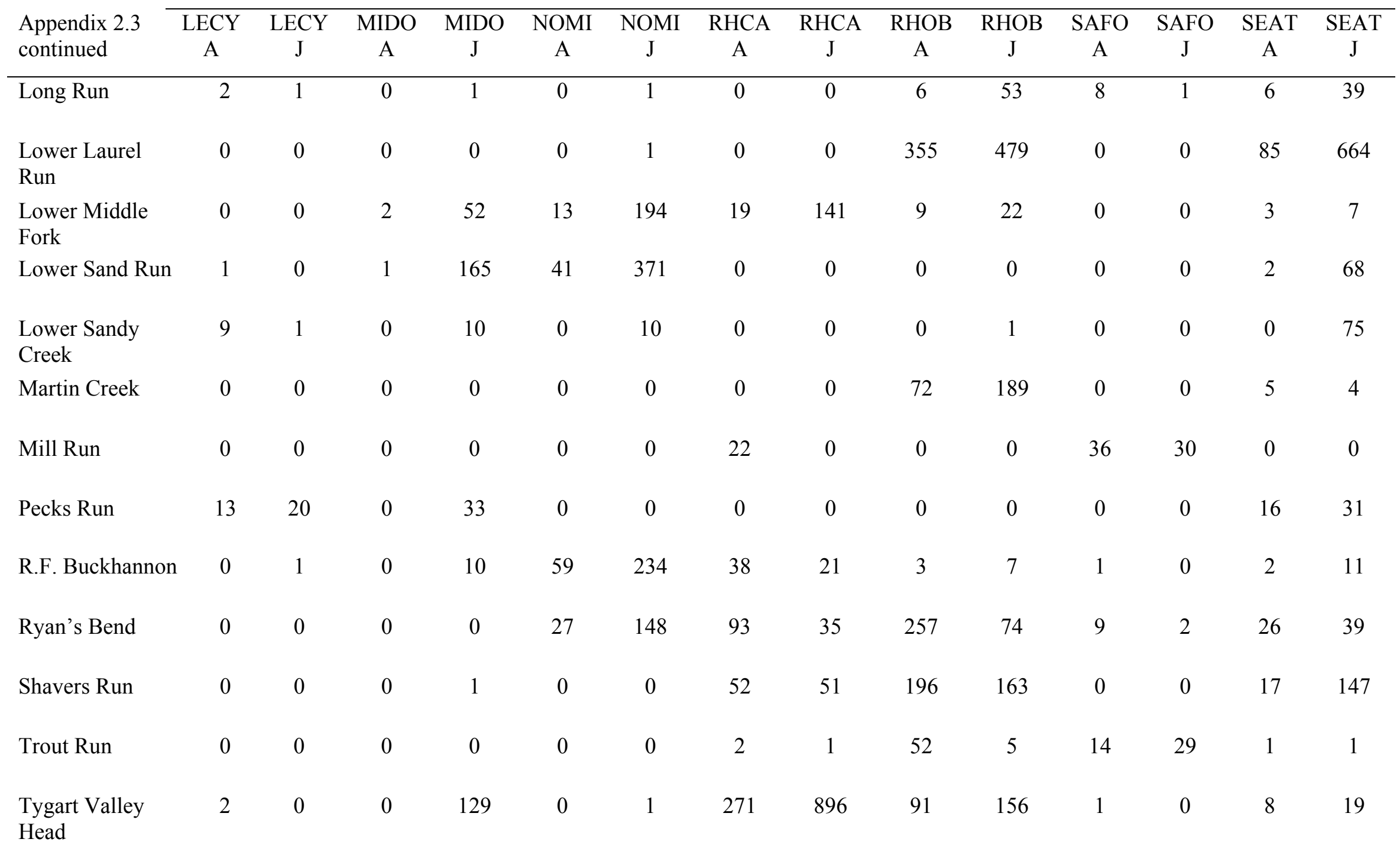




\begin{tabular}{|c|c|c|c|c|c|c|c|c|c|c|c|c|c|c|}
\hline $\begin{array}{l}\text { Appendix } 2.3 \\
\text { continued }\end{array}$ & $\begin{array}{c}\text { LECY } \\
\text { A }\end{array}$ & $\begin{array}{c}\text { LECY } \\
\mathrm{J}\end{array}$ & $\begin{array}{c}\text { MIDO } \\
\text { A }\end{array}$ & $\begin{array}{l}\text { MIDO } \\
\mathrm{J}\end{array}$ & $\begin{array}{l}\text { NOMI } \\
\text { A }\end{array}$ & $\begin{array}{l}\text { NOMI } \\
\mathrm{J}\end{array}$ & $\begin{array}{c}\text { RHCA } \\
\text { A }\end{array}$ & $\begin{array}{c}\text { RHCA } \\
\text { J }\end{array}$ & $\begin{array}{c}\text { RHOB } \\
\text { A }\end{array}$ & $\begin{array}{c}\text { RHOB } \\
\mathrm{J}\end{array}$ & $\begin{array}{c}\text { SAFO } \\
\text { A }\end{array}$ & $\begin{array}{c}\text { SAFO } \\
\mathrm{J}\end{array}$ & $\begin{array}{l}\text { SEAT } \\
\text { A }\end{array}$ & $\begin{array}{c}\text { SEAT } \\
\mathrm{J}\end{array}$ \\
\hline Raccoon Creek & 0 & 0 & 0 & 0 & 0 & 0 & 0 & 0 & 55 & 58 & 0 & 0 & 47 & 169 \\
\hline UNT Laurel & 0 & 0 & 0 & 0 & 0 & 0 & 0 & 0 & 153 & 49 & 0 & 0 & 25 & 126 \\
\hline UNT Little Sandy & 0 & 0 & 0 & 7 & 11 & 85 & 0 & 0 & 57 & 57 & 0 & 0 & 33 & 299 \\
\hline UNT Raccoon & 0 & 0 & 0 & 0 & 0 & 0 & 0 & 0 & 176 & 42 & 0 & 0 & 10 & 41 \\
\hline $\begin{array}{l}\text { Upper Middle } \\
\text { Fork }\end{array}$ & 3 & 0 & 0 & 0 & 0 & 0 & 16 & 0 & 243 & 38 & 38 & 44 & 4 & 2 \\
\hline $\begin{array}{l}\text { Upper R.F. } \\
\text { Buckhannon }\end{array}$ & 0 & 0 & 0 & 0 & 0 & 0 & 14 & 18 & 225 & 109 & 4 & 0 & 35 & 76 \\
\hline $\begin{array}{l}\text { Windy Run of } \\
\text { Tygart }\end{array}$ & 0 & 0 & 0 & 0 & 0 & 0 & 169 & 225 & 148 & 622 & 2 & 0 & 1 & 1 \\
\hline York Run & 1 & 0 & 0 & 0 & 0 & 0 & 0 & 0 & 129 & 5 & 0 & 0 & 66 & 117 \\
\hline Tygart 219 & 10 & 72 & 9 & 30 & 15 & 46 & 3 & 11 & 0 & 0 & 0 & 0 & 0 & 9 \\
\hline Crab Orchard Run & 0 & 0 & 0 & 0 & 0 & 0 & 0 & 0 & 0 & 0 & 0 & 0 & 19 & 10 \\
\hline
\end{tabular}

